Article

\title{
Rare Earth Elements (REE) Deposits Associated with Great Plain Margin Deposits (Alkaline-Related), Southwestern United States and Eastern Mexico
}

\author{
Virginia T. McLemore \\ New Mexico Bureau of Geology and Mineral Resources, New Mexico Institute of Mining and Technology, \\ Socorro, NM 87801, USA; Virginia.Mclemore@nmt.edu; Tel.: +1-575-835-5521
}

Received: 13 November 2017; Accepted: 18 January 2018; Published: 23 January 2018

\begin{abstract}
W.G. Lindgren in 1933 first noted that a belt of alkaline-igneous rocks extends along the eastern edge of the Rocky Mountains and Basin and Range provinces from Alaska and British Columbia southward into New Mexico, Trans-Pecos Texas, and eastern Mexico and that these rocks contain relatively large quantities of important commodities such as, gold, fluorine, zirconium, rare earth elements (REE), tellurium, gallium, and other critical elements. In New Mexico, these deposits were called Great Plain Margin (GPM) deposits, because this north-south belt of alkaline-igneous rocks roughly coincides with crustal thickening along the margin between the Great Plains physiographic province with the Basin and Range (including the Rio Grande rift) and Rocky Mountains physiographic provinces, which extends into Trans-Pecos Texas and eastern Mexico. Since 1996, only minor exploration and development of these deposits in New Mexico, Texas, and eastern Mexico has occurred because of low commodity prices, permitting issues, and environmental concerns. However, as the current demand for gold and critical elements, such as REE and tellurium has increased, new exploration programs have encouraged additional research on the geology of these deposits. The lack of abundant quartz in these systems results in these deposits being less resistant to erosion, being covered, and not as well exposed as other types of quartz-rich deposits, therefore additional undiscovered alkaline-related gold and REE deposits are likely in these areas. Deposits of Th-REE-fluorite $( \pm \mathrm{U}, \mathrm{Nb})$ epithermal veins and breccias are found in the several GPM districts, but typically do not contain significant gold, although trace amounts of gold are found in most GPM districts. Gold-rich deposits in these districts tend to have moderate to low REE and anomalously high tungsten and sporadic amounts of tellurium. Carbonatites are only found in New Mexico and Mexico. The diversity of igneous rocks, including alkaline-igneous rocks, and associated mineral deposits along this boundary suggests that this region is characterized by highly fractionated and differentiated, multiple pulses of mantle-derived magmas evolving to lower crustal magmas related to the subduction of the Farallon plate. The differences in incompatible trace elements, including REE and beryllium, between the different granitic to rhyolite rocks are likely related to either differences in the crustal rocks that were assimilated during magmatic differentiation or by potential minor contamination from crustal sources and/or magma mixing. Deep-seated fracture systems or crustal lineaments apparently channeled the magmas and hydrothermal fluids. Once magmas and metal-rich fluids reached shallow levels, the distribution and style of these intrusions, as well as the resulting associated mineral deposits were controlled by local structures and associated igneous rock compositions.
\end{abstract}

Keywords: gold; REE; alkaline-igneous related deposits; alkaline-igneous rocks; carbonatites 


\section{Introduction}

Lindgren [1] first noted that a belt of alkaline-igneous rocks extends along the eastern edge of the Rocky Mountains and Basin and Range provinces from Alaska and British Columbia southward into New Mexico, Trans-Pecos Texas, and eastern Mexico. These rocks are associated with relatively large quantities of gold, fluorine, zirconium, rare earth elements (REE), tellurium, gallium, and other critical elements [2-5] and over the years, many commodities, especially gold and molybdenum, have been produced from the North American Cordilleran alkaline-igneous belt. Deposits within this belt that have produced significant amounts of gold in the United States and Canada include Cripple Creek, Colorado (731 metric tons of gold production) [5], Black Hills, South Dakota (235 metric tons gold production) and Landsky-Zortman, Montana (71 metric tons gold and 586 metric tons silver production) [6]. Although there has been little REE production from these deposits in the past, exploration is occurring and some could be productive in the future, such as the Bear Lodge Mountains carbonatite deposit in Wyoming, where more than 16.3 million metric tons of $3.05 \%$ total REE are reported $[7,8]$.

Rare earth elements (REE) and other critical elements are increasingly becoming more important in our technological society, and because of the chemical and physical properties of REE, they are used in many diverse defense, energy, industrial, and military applications, like cell phones, computers, magnets, batteries, solar panels, and wind turbines [7-12]. REE include the 15 lanthanide elements (atomic number 57 to 71), yttrium ( $Y$, atomic number 39), and scandium (Sc, atomic number 21; Table 1) and are commonly divided into two chemical groups, the light REE (La through Eu) and the heavy REE (Gd through Lu and Y). REE are lithophile elements (or elements enriched in the crust) that have similar physical and chemical properties, and, therefore, occur together in nature. The name REE is misleading; the content of the REE in the earth's crust ranges from $60 \mathrm{ppm}$ for Ce to $\sim 0.5 \mathrm{ppm}$ for $\mathrm{Tb}$ and $\mathrm{Lu}$, which is greater than the crustal abundance of silver (Ag). Four REE (Y, La, Ce and Nd) have larger crustal abundances than lead $(\mathrm{Pb})[8,9]$. However, REE are not always concentrated in easily mined economic deposits and only a few deposits in the world account for current production [8-14]. The U.S. once produced enough REE for U.S. consumption, but since 1999 more than $95 \%$ to $100 \%$ of the REE required by U.S. industries have been imported from China $[9,14-16]$. However, the projected increase in demand for REE in China, India, United States, and other countries $[8,9,12]$ could result in increased exploration and ultimate production from future deposits in the U.S. and elsewhere [16]. REE deposits have been reported and produced from New Mexico [17-19], but were not considered important exploration targets because the demand in past years has been met by other deposits in the world. Also there are potential permitting and environmental issues that hamper exploration and development in the U.S. However, with the projected increase in demand and potential uncertainty of available production from the Chinese deposits, these areas in New Mexico, Texas, and eastern Mexico should be re-examined for their REE potential.

The North American Cordilleran alkaline-igneous belt is a north-south belt of alkaline-igneous rocks and crustal thickening, roughly coinciding with the Great Plains physiographic margin with the Rocky Mountains and the Basin and Range (including the Rio Grande rift) physiographic provinces (Figure 1) [2,3,20-26]. Chapin et al. [27] referred to this zone as the Rocky Mountain front. Other names include the Eastern Alkalic Belt [28] and the Rocky Mountain Gold Province. In New Mexico, the mineral deposits found in the North American Cordilleran alkaline-igneous belt are associated with Eocene-Oligocene alkaline to calc-alkaline rocks that were called Great Plain Margin (GPM) deposits [23,24,29-32]. This term is retained in this paper and extended to include similar deposits in Trans-Pecos Texas and eastern Mexico.

In New Mexico, the GPM portion of the North American Cordilleran alkaline-igneous belt extends near Raton, southward to the Trans-Pecos alkaline belt (Figure 2). The GPM belt continues into Trans-Pecos Texas and northeastern Mexico. The GPM deposits in New Mexico, Texas, and Mexico are east of the Rio Grande rift, along the border with the Great Plains. 
Many authors have used different classification schemes in describing the mineral deposits found in the North American Cordilleran alkaline-igneous belt. Alternative classifications of these mineral deposits by other workers include Au-Ag-Te veins [33-36], alkalic-gold or alkaline-igneous related gold deposits [2,3,20-22,25,37-39], and porphyry gold deposits [39,40]. REE also are associated with peralkaline intrusion-related igneous systems and some are found in the North American Cordilleran alkaline-igneous belt, but not in New Mexico ([8,39,41], this report). The U.S. Geological Survey mineral deposit classification system is used in this study with minor modifications $[8,32,34,39]$.

There are nine types of deposits found in GPM districts in New Mexico, Texas, and Mexico (revised from [19,23,24,32]): (1) polymetallic, epithermal to mesothermal veins (USGS model no. 17, 22b, 22c [33,39]), (2) breccia pipes (USGS model no. 10b, 11d [32,33,39]), (3) porphyry copper-molybdenum-gold (USGS model no. 20c, 21a, 16 [32,39,40]), (4) copper, lead-zinc, and/or gold skarns and/or carbonate-hosted replacement deposits (USGS model no. 18b, 18c, 19a [32,39]), (5) iron skarns and replacement bodies (USGS model no. 18d [32,39]), (6) Th-REE-fluorite ( $\pm \mathrm{U}, \mathrm{Nb}$ ) epithermal veins and breccias (USGS model no. 10b, 11d [32,39]), (7) carbonatites (USGS model no. 10 [8,32,39]), (8) peralkaline intrusion-related REE deposits (USGS model no. 11 [8,39,41]) and (9) placer gold (USGS model no. 39a [32,39]) (Table 1). Additional types of deposits are locally found spatially (and perhaps genetically) in the vicinity of GPM deposits: fluorspar vein and breccia deposits (USGS model no. 26b [39]), tungsten-bearing veins (USGS model no. 15a [39]), and volcanogenic beryllium deposits [42]. Most of these deposits are proximal magmatic deposits, whereas iron skarns and replacement bodies are more distal magmatic deposits. Placer gold deposits have been weathered from their original source and have either accumulated in place or been transported, generally by water.

Alkaline- to sub-alkaline-igneous rocks are found in all GPM districts, but gold mineralization is locally associated with older, more silica-saturated (monzonite) or oversaturated (quartz monzonite) rocks [21,24,43-46]. Alkaline-igneous rocks are enriched in sodium and potassium $\left(\mathrm{Na}_{2} \mathrm{O}, \mathrm{K}_{2} \mathrm{O}\right)$ relative to similar rocks at given silica $\left(\mathrm{SiO}_{2}\right)$ content. Most GPM deposits are associated with Oligocene intrusive rocks, 38-23 Ma (Figure 2; Table 1), except for the deposits in the Jicarilla Mountains and Orogrande districts, which are associated with Eocene intrusive rocks (39.45-45.6 Ma) (Table 1; [45]). The larger, more productive gold deposits are found in northern and central New Mexico (Figure 2; Table 1). Carbonatites, which are the world's largest economic source of REE today [8], are found only at Laughlin Peak (Chico Hills, Colfax County) [44] and in eastern Mexico [47], but are suspected to occur at depth in the Gallinas Mountains (Table 1).

Since 1996, only minor exploration and development of these REE deposits has occurred because of low commodity prices, permitting issues, and environmental concerns. However, one important change is that now there is an increased demand for critical elements like REE, tellurium, niobium, and other elements that are found in the North American Cordilleran alkaline-igneous belt, including New Mexico's GPM districts $[8,10,48]$. In addition, new geochemical and geochronological data are available in many GPM districts in New Mexico, Texas, and eastern Mexico. Many GPM districts in New Mexico have been mapped or re-mapped as part of the New Mexico Bureau of Geology and Mineral Resources (NMBGMR) geologic mapping program, including the Ortiz porphyry belt, Santa Fe County and the southern Lincoln County porphyry belt (Table 1; http:/ / geoinfo.nmt.edu/publications/maps / geologic/ofgm/home.cfml, accessed 21 January, 2018). This new mapping, along with geochemical and geochronological studies, have revised the volcanic stratigraphy and enhanced our knowledge of the timing of magmatic events, mineralogy and geochemistry, and geologic processes forming GPM deposits in New Mexico. New research at the Round Top Mountain deposit at Sierra Blanca, Texas and newly discovered carbonatites in Mexico also have increased our area of economic interest to the south to include Trans-Pecos Texas and eastern Mexico. Thus, the purposes of this paper are to (1) summarize the geology, geochemistry, geochronology and mineral production of Eocene-Oligocene alkaline-igneous related GPM mineral deposits in New Mexico, Texas, and eastern Mexico, (2) discuss the age and formation of these deposits, and (3) comment on the future economic potential of these mineral deposits in New Mexico, Texas and eastern Mexico. Earlier papers [23,24] described the gold 
potential of GPM deposits in New Mexico; this paper focuses on the REE potential of GPM deposits. This work is part of ongoing studies of mineral deposits in New Mexico and includes updates and revisions of prior work $[4,23,24,30,31,48]$.

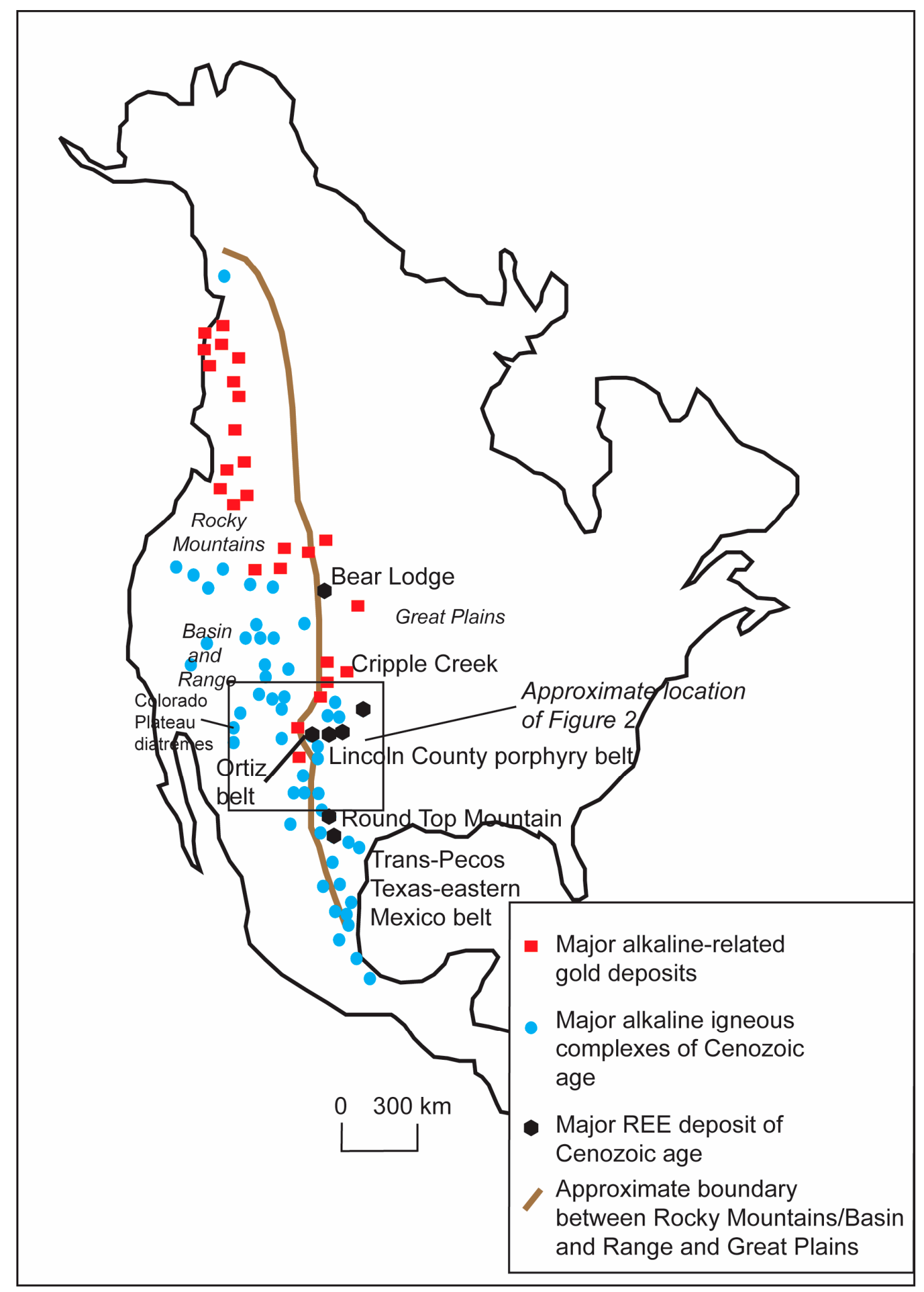

Figure 1. Extent of the North American Cordilleran alkaline-igneous belt $[2,3,23,24,49]$. 


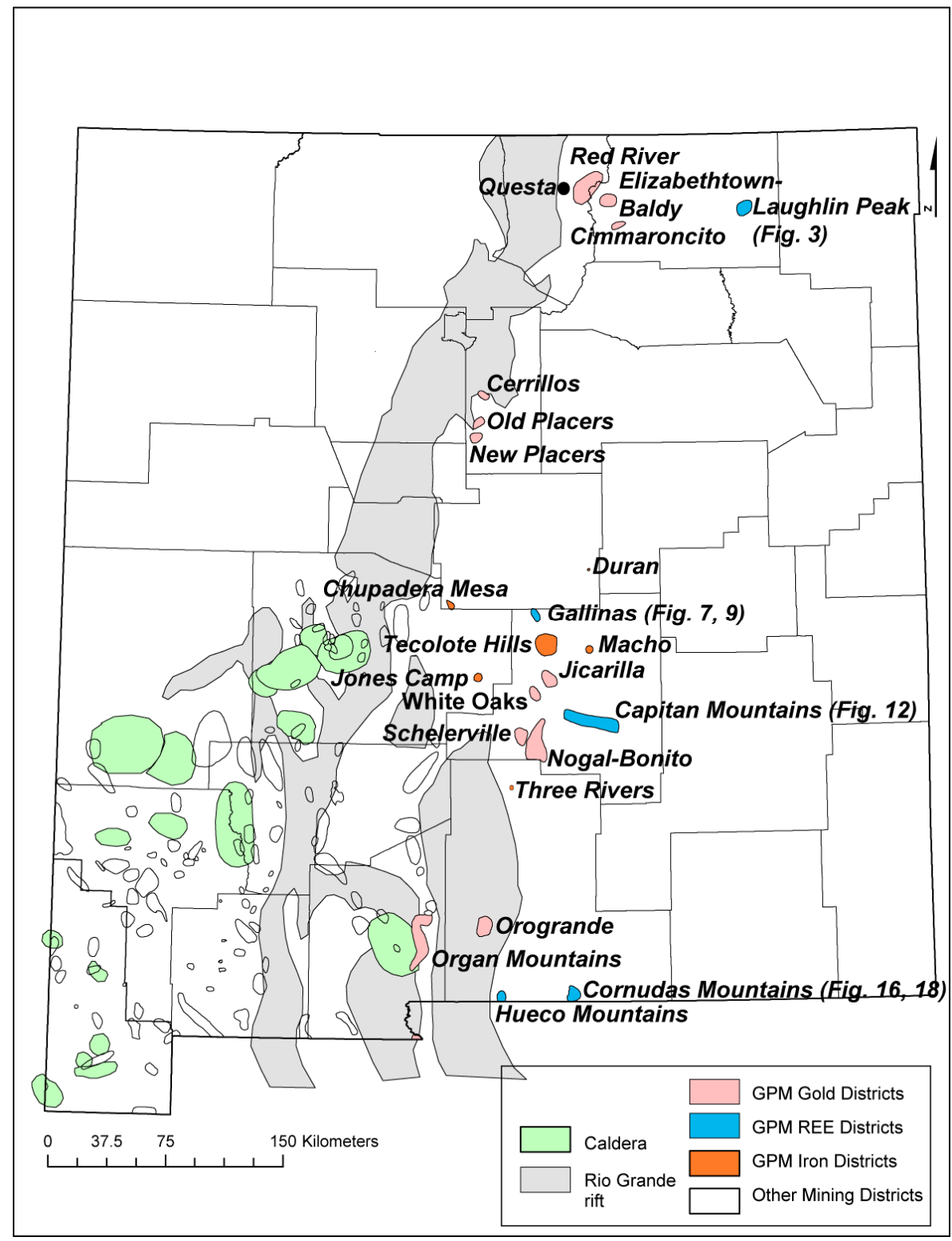

Figure 2. Mining districts related to the North American Cordilleran alkaline-igneous belt (GPM or Great Plains Margin deposits), Rio Grande rift, calderas, and other Eocene-Miocene mining districts in New Mexico [23,24,27,31,32,48-54]. GPM districts are summarized in Table 1. 
Table 1. GPM mining districts related to the North American Cordilleran alkaline-igneous belt in New Mexico, Texas, and eastern Mexico. The mining districts are arranged roughly from north to south, Cripple Creek is included only for comparison to the southern districts. Names of mining districts in New Mexico are after File and Northrop [55] wherever practical, but some former districts have been combined and new districts added. The district id number refers to the New Mexico Mines Database district number [53,54]. Locations of districts in New Mexico are shown in Figure 2. Types of deposits are numbered as discussed in the text below and are described in McLemore and Lueth [32]. Magmatic characteristics are using geochemical and tectonic diagrams [56-61]. Database of geochemical analyses used is in supplemental material. WPG $=$ within plate granite. $\mathrm{VAG}=$ volcanic arc granite. Gold production is from $[5,26,62]$. na $=$ not available.

\begin{tabular}{|c|c|c|c|c|c|c|c|}
\hline District ID & Name & $\begin{array}{l}\text { Associated Elements } \\
\text { (Produced Are in Bold } \\
\text { Italics) }\end{array}$ & $\begin{array}{l}\text { Age Ma (Bold Italics Are } \\
\left.\qquad{ }_{40} \mathrm{Ar}{ }^{39} \mathrm{Ar}\right)\end{array}$ & Type of Mineral Deposits & Magmatic Characteristics [56-61] & $\begin{array}{c}\text { Gold Production } \\
\text { (Metric Tons)*Gold } \\
\text { Resources Remain }\end{array}$ & Selected References \\
\hline na & $\begin{array}{l}\text { Cripple Creek, } \\
\text { CO }\end{array}$ & $A \boldsymbol{u}, A g, F, \mathrm{Te}$ & $32-37$ & $\begin{array}{l}\text { Veins (1), breccia pipes (2), gold } \\
\text { placers (9) }\end{array}$ & na & 731 * & {$[5,26,63]$} \\
\hline DIS237 & Questa & $\mathrm{Mo}, \mathrm{Be}, \mathrm{F}$ & $22.7-28.5$ & $\begin{array}{l}\text { Veins (1), breccia pipes (2), Mo } \\
\text { porphyry (3) }\end{array}$ & $\begin{array}{l}\text { Magnesian to ferroan, subalkaline, } \\
\text { alkali-calcic to calc-alkalic, } \\
\text { metaluminous to peraluminous }\end{array}$ & 0 & {$[53,63-71]$} \\
\hline DIS238 & Red River & $A u, A g, C u, \mathrm{Mo}, \mathrm{Be}, \mathrm{Te}$ & 24.9 & Veins (1), gold placers (9) & $\begin{array}{c}\text { Magnesian, subalkaline, alkali to } \\
\text { alkali-calcic, metaluminous to } \\
\text { peraluminous }\end{array}$ & 0.01 * & {$[66,67,71-73]$} \\
\hline DIS019 & Elizabethtown-Baldy & $A u, A g, \mathrm{~W}, \mathrm{Te}$ & 29.1 & $\begin{array}{l}\text { Veins (1), } \mathrm{Cu}, \mathrm{Pb}, \mathrm{Zn} \text {, Au skarns } \\
(4) \text {, Fe skarns (5), gold placers ( }(9)\end{array}$ & $\begin{array}{l}\text { Magnesian to ferroan, subalkaline, } \\
\text { alkali to calc-alkalic, metaluminous } \\
\text { to peraluminous }\end{array}$ & $14.6^{*}$ & [73-77] \\
\hline DIS018 & Cimarroncito & $A u, A g$ & 29.1 & Veins (1), gold placers (9) & $\begin{array}{l}\text { Magnesian to ferroan, subalkaline, } \\
\text { alkali to calc-alkalic, metaluminous } \\
\text { to peraluminous }\end{array}$ & 0.003 & {$[73,75-77]$} \\
\hline DIS020 & Laughlin Peak & REE, Th, U, F & $22.8-32.3$ & $\begin{array}{l}\text { Veins (1), breccia pipes (2), } \\
\text { Th-REE veins (6), carbonatites (7) }\end{array}$ & $\begin{array}{c}\text { Ferroan to magnesian, metaluminous } \\
\text { to peralkaline, mostly alkaline, } \\
\text { mostly alkali, WPG }\end{array}$ & 0 & {$[44,78-83]$} \\
\hline DIS180 & Cerrillos & $A u, A g, C u$ & 28.9 & Veins (1), porphyry (3) & $\begin{array}{l}\text { calc-alkalic to alkaline, ferroan to } \\
\text { magnesian, calc-alkalic to alkalic, } \\
\text { metaluminous to peraluminous } \\
\text { rocks, and plot as WPG to VAG }\end{array}$ & $0.08 *$ & {$[73,84,85]$} \\
\hline DIS186 & New Placers & $A u, A g, C u, T e$ & $33.7-33.9$ & $\begin{array}{l}\text { Veins (1), } \mathrm{Cu}, \mathrm{Pb}, \mathrm{Zn} \text {, Au skarns } \\
\text { (4), gold placers (9) }\end{array}$ & $\begin{array}{l}\text { calc-alkalic to alkaline, ferroan to } \\
\text { magnesian, calc-alkalic to alkalic, } \\
\text { metaluminous to peraluminous } \\
\text { rocks, and plot as WPG to VAG }\end{array}$ & $3.6^{*}$ & {$[73,86,87]$} \\
\hline DIS187 & Old Placers & $A \boldsymbol{u}, A g, C u, \mathrm{~W}, \mathrm{Te}$ & $34.3-35.8,33.3-31.7$ & $\begin{array}{l}\text { Veins (1), breccia pipes (2), } \\
\text { porphyry (3), Cu, Pb, Zn, Au } \\
\text { skarns (4), gold placers (9) }\end{array}$ & $\begin{array}{l}\text { calc-alkalic to alkaline, ferroan to } \\
\text { magnesian, calc-alkalic to alkalic, } \\
\text { metaluminous to peraluminous } \\
\text { rocks, and plot as WPG to VAG }\end{array}$ & $14^{*}$ & {$[73,86-91]$} \\
\hline DIS271 & Duran & $\mathrm{Fe}$ & $?$ & Fe skarns (5) & na & 0 & {$[92,93]$} \\
\hline DIS092 & $\begin{array}{l}\text { Gallinas } \\
\text { Mountains }\end{array}$ & $C u, A g, R E E, F, \mathrm{Th}, \mathrm{U}, \mathrm{Te}$ & $26.5-29.7$ & $\begin{array}{l}\text { Veins (1), breccia pipes (2), Fe } \\
\text { skarns (5), Th-REE veins (6), } \\
\text { carbonatites?? (7) }\end{array}$ & $\begin{array}{l}\text { Ferroan, metaluminous to } \\
\text { peraluminous, alkaline, mostly alkali } \\
\text { to alkali-calcic, A-type, WPG }\end{array}$ & $<0.001$ & {$[73,92,94-111]$} \\
\hline DIS098 & Tecolote Iron & $\mathrm{Fe}$ & $?$ & Fe skarns (5) & na & 0 & {$[92,94,112]$} \\
\hline
\end{tabular}


Table 1. Cont

\begin{tabular}{|c|c|c|c|c|c|c|c|}
\hline District ID & Name & $\begin{array}{c}\text { Associated Elements } \\
\text { (Produced Are in Bold } \\
\text { Italics) }\end{array}$ & $\begin{array}{l}\text { Age } \mathrm{Ma} \text { (Bold Italics Are } \\
\left.{ }_{40} \mathrm{Ar}^{39} \mathrm{Ar}\right)\end{array}$ & Type of Mineral Deposits & Magmatic Characteristics [56-61] & $\begin{array}{l}\text { Gold Production } \\
\text { (Metric Tons)* Gold } \\
\text { Resources Remain }\end{array}$ & Selected References \\
\hline DIS093 & Jicarilla & $A u, A g, F e$ & $39.16-45.63$ & $\begin{array}{c}\text { Veins (1), breccia pipes (2), Cu, } \\
\mathrm{Pb}, \mathrm{Zn} \text {, Au skarns (4), Fe skarns } \\
\text { (5), gold placers (9) }\end{array}$ & $\begin{array}{l}\text { subalkaline to alkaline, ferroan to } \\
\text { magnesian, calc-alkalic to alkali, } \\
\text { metaluminous to peraluminous, VAG }\end{array}$ & $0.3^{*}$ & $\begin{array}{l}{[94,113,114] \text {, unpublished }} \\
\text { data }\end{array}$ \\
\hline DIS099 & $\begin{array}{c}\text { White Oaks } \\
\text { (Lone Mountain) }\end{array}$ & $A \boldsymbol{u}, A g, W, \mathrm{Te}$ & $31.7,34,34.75$ & $\begin{array}{l}\text { Veins (1), } \mathrm{Cu}, \mathrm{Pb}, \mathrm{Zn}, \text { Au skarns } \\
(4), \text { Fe skarns (5), gold placers ( }(9)\end{array}$ & na & $5.1^{*}$ & $\begin{array}{l}{[73,92,94,115-118]} \\
\text { unpublished data }\end{array}$ \\
\hline DIS091 & $\begin{array}{l}\text { Capitan } \\
\text { Mountains }\end{array}$ & $F e, \mathrm{REE}, \mathrm{Th}, \mathrm{U}, \mathrm{F}, \mathrm{Be}$ & 28.3 & $\begin{array}{l}\text { Veins (1), Fe skarns (5), Th-REE } \\
\text { veins (6) }\end{array}$ & $\begin{array}{l}\text { Ferroan to magnesian, peralkaline to } \\
\text { peraluminous, subalkaline, alkalic to } \\
\text { calc-alkalic, A-type, WPG }\end{array}$ & 0 & {$[43,46,73,92,94,119-129]$} \\
\hline DIS095 & Nogal-Bonito & $\begin{array}{c}A u, A g, C u, \mathrm{Mo}, F e, \mathrm{Te}, \\
\text { REE(?) }\end{array}$ & $26-33$ & $\begin{array}{c}\text { Veins (1), porphyry (3), } \mathrm{Cu}, \mathrm{Pb}, \\
\mathrm{Zn} \text {, Au skarns (4), Fe skarns (5), } \\
\text { Th-REE veins?? (6), gold placers } \\
\text { (9) }\end{array}$ & $\begin{array}{l}\text { Metaluminous to peraluminous, } \\
\text { mostly alkaline, alkali to calc-alkalic, } \\
\text { WPG to VAG, A-type to I and S-type }\end{array}$ & $0.5^{*}$ & {$[37,38,73,94,130-143]$} \\
\hline DIS096 & Schelerville & $A u, A g$ & $26-33$ & Veins (1), gold placers (9) & $\begin{array}{l}\text { Metaluminous to peraluminous, } \\
\text { mostly alkaline, alkali to calc-alkalic, } \\
\text { WPG to VAG, A-type to I and S-type }\end{array}$ & $<0.01$ & {$[73,94,140-144]$} \\
\hline DIS132 & Three Rivers & $F e, \mathrm{Au}, \mathrm{Ag}, \mathrm{REE} ?$ & $28.95-28.24$ & $\begin{array}{l}\text { Veins (1), Th-REE veins?? (6), Fe } \\
\text { skarns (5) }\end{array}$ & $\begin{array}{l}\text { Ferroan, metaluminous, alkaline, } \\
\text { alkali-calcic, VAG }\end{array}$ & 0 & {$[92,141-143,145]$} \\
\hline DIS216 & Jones Camp & $\mathrm{Fe}, \mathrm{Au}$ & 28.88 & Fe skarns (5) & $\begin{array}{l}\text { Magnesian, metaluminous, alkaline, } \\
\text { alkali to alkali-calcic }\end{array}$ & 0 & {$[92,146]$} \\
\hline DIS241 & Chupadera Mesa & $\mathrm{Fe}, \mathrm{Au}$ & 30.2 & Fe skarns (5) & $\begin{array}{l}\text { Magnesian to ferroan, metaluminous, } \\
\text { alkaline, alkali to alkali-calcic }\end{array}$ & 0 & {$[92,93,147]$} \\
\hline DIS129 & Orogrande & $C u, A u, A g, F e, \mathrm{Te}$ & $45.6-41.4$ & $\begin{array}{l}\text { Veins (1), porphyry (3), } \mathrm{Cu}, \mathrm{Pb}, \\
\mathrm{Zn} \text {, Au skarns (4), Fe skarns (5), } \\
\text { gold placers (9) }\end{array}$ & $\begin{array}{l}\text { Magnesian to ferroan, metaluminous } \\
\text { to peraluminous, alkaline to } \\
\text { subalkaline, alkali to calcic, WPG to } \\
\text { VAG }\end{array}$ & 0.5 * & {$[45,73,148]$} \\
\hline DIS030 & $\begin{array}{l}\text { Organ } \\
\text { Mountains }\end{array}$ & $\begin{array}{c}C u, P b, Z n, A u, A g, F, \mathrm{Te} \\
\mathrm{Be}\end{array}$ & $26-36.45$ & $\begin{array}{l}\text { Veins (1), porphyry (3), } \mathrm{Cu}, \mathrm{Pb} \text {, } \\
\mathrm{Zn} \text {, Au skarns (4) }\end{array}$ & $\begin{array}{c}\text { alkaline, ferroan to magnesian, } \\
\text { predominantly alkalic, metaluminous } \\
\text { to peraluminous, and plot as WPG to } \\
\text { VAG }\end{array}$ & 0.35 & {$[73,149-157]$} \\
\hline DIS128 & $\begin{array}{l}\text { Cornudas } \\
\text { Mountains }\end{array}$ & REE, Th, U, Be & 36.3 & $\begin{array}{l}\text { Veins (1), breccia pipes (2), } \\
\text { Th-REE veins (6) }\end{array}$ & $\begin{array}{c}\text { Ferroan, metaluminous to } \\
\text { peralkaline, alkaline, alkali, WPG }\end{array}$ & 0 & [28,158-171] \\
\hline DIS255 & $\begin{array}{l}\text { Hueco } \\
\text { Mountains }\end{array}$ & $\mathrm{Fe}, \mathrm{REE}, \mathrm{Th}, \mathrm{U}$ & $34.5-34.7$ & Fe skarns (5), Th-REE veins (6) & $\begin{array}{l}\text { Ferroan, metaluminous to } \\
\text { peralkaline, alkaline, alkali, WPG to } \\
\text { VAG }\end{array}$ & 0 & {$[171,172]$} \\
\hline
\end{tabular}


Table 1. Cont.

\begin{tabular}{|c|c|c|c|c|c|c|c|}
\hline District ID & Name & $\begin{array}{c}\text { Associated Elements } \\
\text { (Produced Are in Bold } \\
\text { Italics) }\end{array}$ & $\begin{array}{l}\text { Age Ma (Bold Italics Are } \\
\left.{ }^{40} \mathrm{Ar} \mathbf{r}^{39} \mathrm{Ar}\right)\end{array}$ & Type of Mineral Deposits & Magmatic Characteristics [56-61] & $\begin{array}{c}\text { Gold Production } \\
\text { (Metric Tons)* Gold } \\
\text { Resources Remain }\end{array}$ & Selected References \\
\hline na & $\begin{array}{l}\text { Round Top, } \\
\text { Sierra Blanca }\end{array}$ & $\mathrm{REE}, \mathrm{Be}, \mathrm{U}, \mathrm{Th}$ & $36.2 \pm 0.6$ & $\begin{array}{l}\text { Th-REE veins (6), peralkaline } \\
\text { intrusion-related REE deposits (8) }\end{array}$ & $\begin{array}{l}\text { Metaluminous to peraluminous, } \\
\text { WPG }\end{array}$ & 0 & {$[8,42,173-186]$} \\
\hline na & $\begin{array}{l}\text { Villa Ahumada } \\
\text { carbonatites, } \\
\text { Mexico }\end{array}$ & $\mathrm{U}, \mathrm{Th}, \mathrm{REE}$ & $36.35 \pm 0.27$ & Th-REE veins (6), carbonatites (7) & na & 0 & [47] \\
\hline na & $\begin{array}{l}\text { Aguachile } \\
\text { Be-F-U deposit }\end{array}$ & $\mathrm{Be}, \mathrm{F}, \mathrm{U}, \mathrm{REE}$ ? & & $\begin{array}{l}\text { Veins (1), Th-REE veins (6), } \\
\text { peralkaline intrusion-related REE } \\
\text { deposits?? (8) }\end{array}$ & Alkali, peralkaline to peraluminous & 0 & {$[42,49,187-189]$} \\
\hline
\end{tabular}




\section{Materials and Methods}

Seven districts containing REE deposits are highlighted in this report and described in Section 3 of this report. Data used in this report have been compiled from a literature review (references cited in Table 1), field examination and mapping by the author, and include the mineralogy, geochemistry, and geochronology of the alkaline-igneous rocks and associated mineral deposits. The geochemical data, analytical precision and accuracy, and analytical methods are described in the various cited reports (Table 1).

Mineral and chemical compositions of igneous rocks in the GPM districts were obtained from numerous reports as cited, as well as unpublished data by the author, and are in the supplemental material. The data were plotted on various standard geochemical and tectonic diagrams [56-61] and compared. These chemical plots are standard methods used to describe and classify igneous rocks and provide a basis for comparisons between areas (Table 1). Only selected plots are shown for space limitations. A variety of nomenclatures for the igneous rocks in these districts were used in previous studies, because the rocks typically are porphyritic in a fine-grained matrix and include shallow intrusions as well as extrusive volcanic rocks. The International classification [190] is used in this report, where the primary classification of igneous rocks is based upon mineralogy and, if too fine-grained to determine mineralogy, by the use of whole-rock geochemical analyses using the TAS (total alkali silica) [190] and R1-R2 [191] diagrams.

Mineral occurrences, deposits, mines, and prospects within GPM districts were compiled from published and unpublished data, summarized in Table 1, plotted on base maps, and entered in the New Mexico Mines Database [53,54,62]. Mineralized areas were examined and sampled during 1980-2017 by the author and during 1982-1993 by the U.S. Bureau of Mines as part of mineral-resource assessments [82,102,104,119,133,168]. Arc GIS was used for New Mexico deposits and other regional maps were used for Texas and Mexico.

Any resource or reserve data presented here are historical data and are provided for information purposes only and do not conform to Canadian National Instrument NI 43-101 requirements, unless otherwise stated.

\section{Descriptions of Selected Areas}

\subsection{Laughlin Peak District}

The Laughlin Peak district (DIS091), located within the Laughlin Peak-Chico Hills igneous complex (Figure 3), is in the southern portion of the younger Raton-Clayton volcanic field in northeastern New Mexico, along the Jemez Lineament. The Laughlin Peak-Chico Hills complex was emplaced just before or at the beginning of Rio Grande rift extension (22-37 Ma [44]). The Laughlin Peak-Chico Hills igneous complex consists of a variety of alkaline extrusive (trachyandesite, $32.3 \pm 1.5$, $\mathrm{K} / \mathrm{Ar}$; basalt, trachybasalt, rhyodacite) and intrusive lithologies (Figure 4a), including trachyte $(36.7 \pm 1.3 \mathrm{Ma}, \mathrm{K} / \mathrm{Ar}$ [78]), trachyphonolite, trachyandesite, phonotephrite (25.3 $\pm 0.9 \mathrm{Ma}, \mathrm{K} / \mathrm{Ar}$ [79]), Chico Phonolite (22.8 $\pm 0.23 ;{ }^{40} \mathrm{Ar} /{ }^{39} \mathrm{Ar}$ [83]), lamprophyre dikes (24.06 $\pm 1.01 \mathrm{Ma}, \mathrm{K} / \mathrm{Ar}$ [79]), and carbonatite dikes [44]. Many of the volcanic and intrusive rocks have a porphyritic texture, suggesting emplacement near or at the surface. Associated igneous rocks in the Laughlin Peak district are alkaline (Figure 4b; alkali to calc-alkalic according to Frost and Frost [59]), predominantly ferroan to magnesian, metaluminous to peralkaline and plot as A-type granites and WPG (within-plate granites according to Pearce et al. [57]) (Supplemental Material). The associated igneous rocks exhibit typical light REE-enriched chondrite-normalized REE patterns of alkaline-igneous rocks with no europium anomaly (Figure 4c). Veins are hosted by most volcanic rock types, except the carbonatite dikes. 


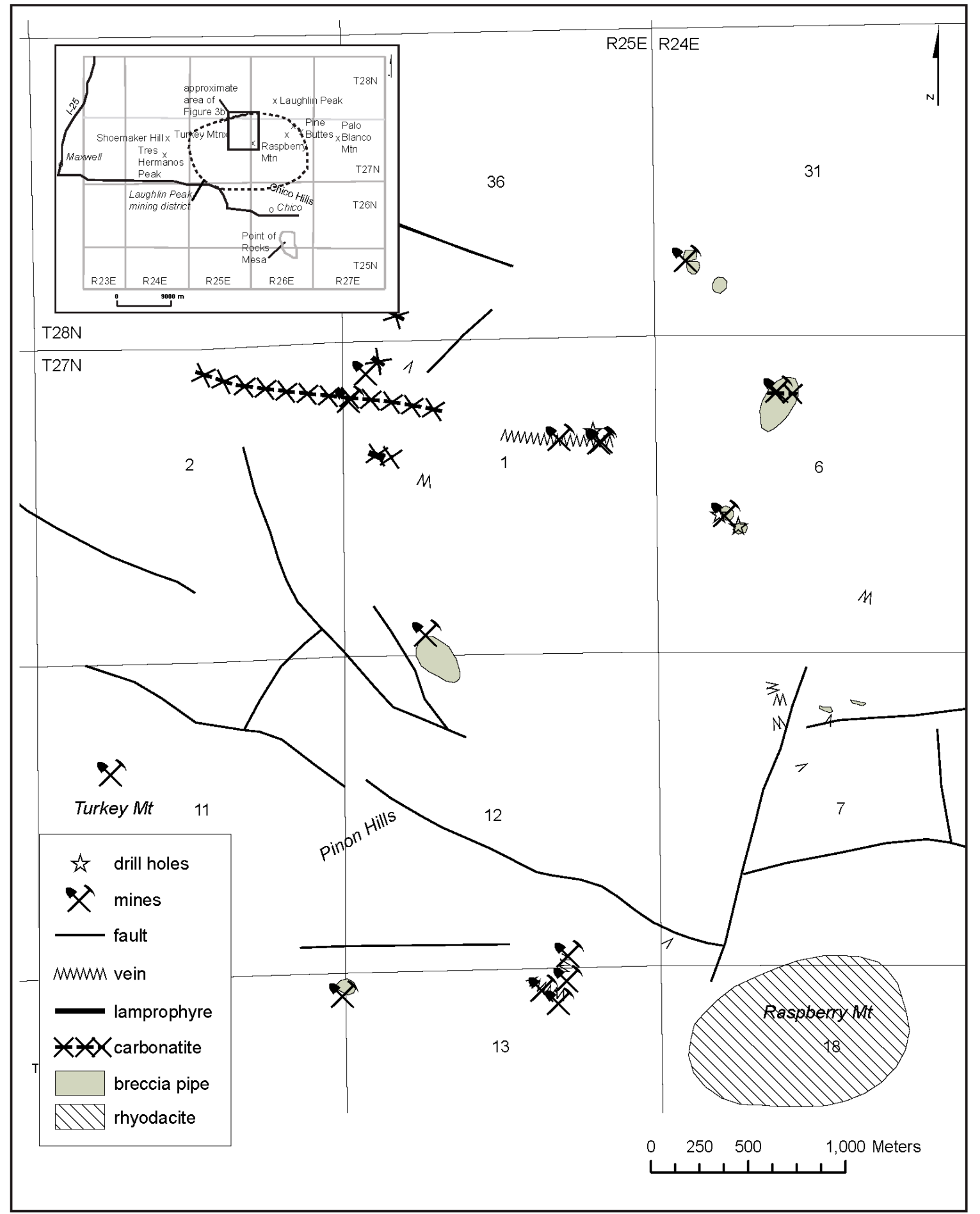

Figure 3. Simplified geologic map of the Laughlin Peak district, Colfax County, New Mexico (simplified from [44,78-80]). Prospects and drill holes are described in McLemore [44]. Gray lines and numbers are township, range and section lines. 


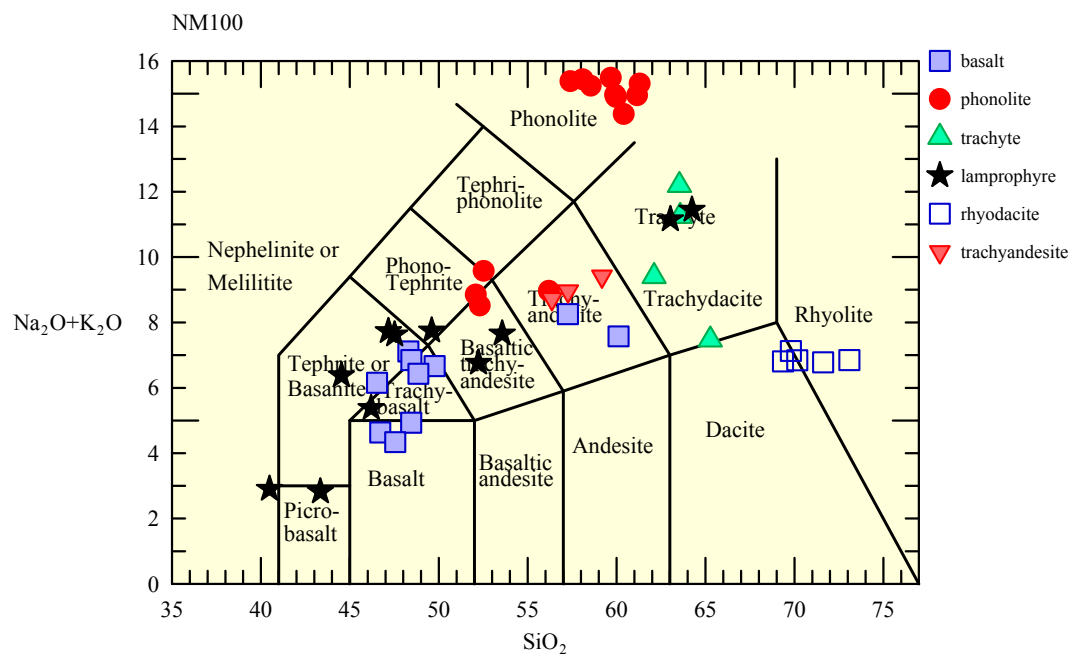

(a)

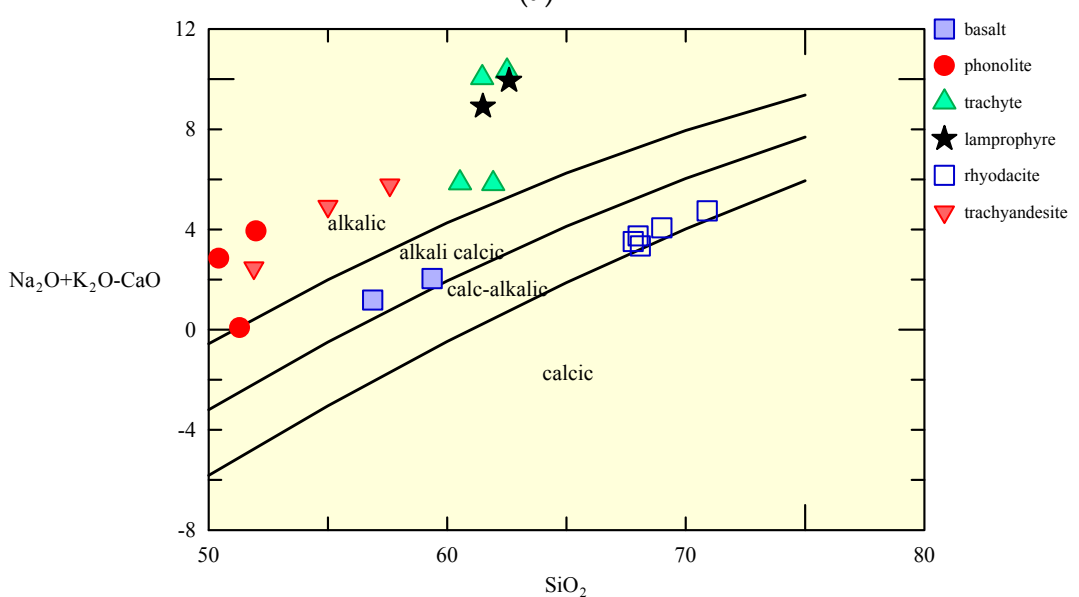

(b)

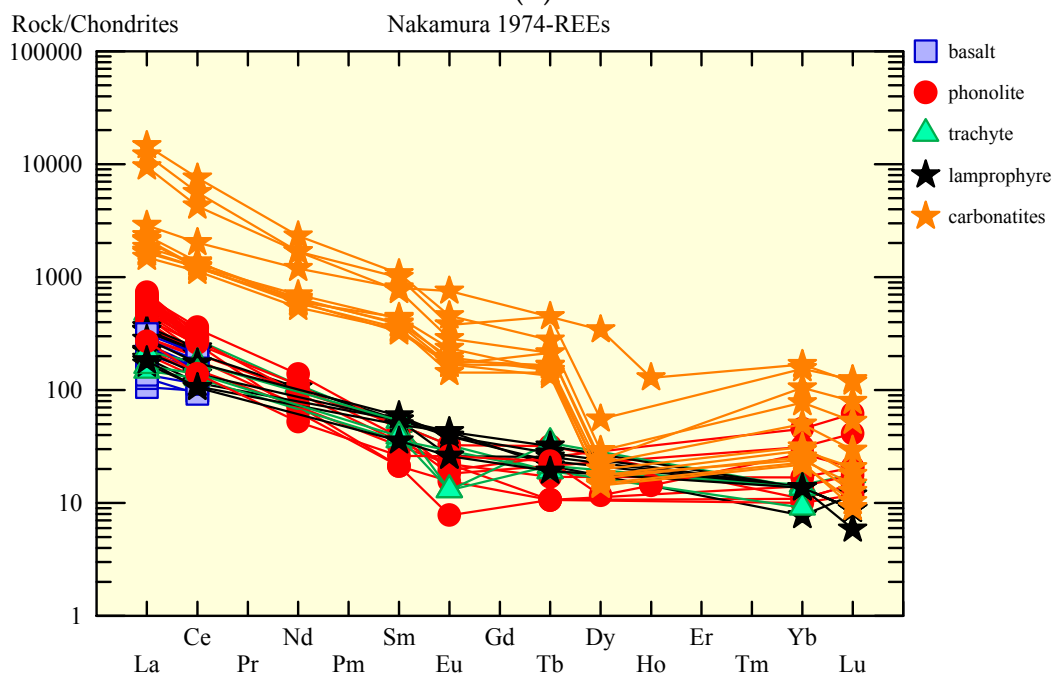

(c)

Figure 4. Chemical plots of igneous rocks from the Laughlin Peak district. Lithological names of samples are from the original data sources $([44,81,82]$, supplemental material). (a) is the TAS (Total Alkali Silica) diagram [190], (b) is alkaline to calc-alkalic diagram [59], and (c) is a chondrite-normalized REE plot [192]. 
Although there has been no mineral production from the Laughlin Peak district, three types of mineral deposits have been identified: (1) carbonatites, (2) breccia pipe deposits, and (3) Th-REE-fluorite $( \pm \mathrm{U}, \mathrm{Nb})$ epithermal veins and breccias [44]. Carbonatite dikes intrude the Oligocene phonotephrite and are radioactive due to the presence of uranium and thorium minerals [44,82] and have the chemical composition of predominantly calciocarbonatite (Figure 5; also known as calcite carbonatite or sövite; after $[193,194]$ ), with minor ferrocarbonatite and magnesiocarbonatite (also known as dolomite carbonatite or beforsite). The carbonatites are poorly exposed and range in size from $12 \mathrm{~m}$ to $1219 \mathrm{~m}$ long and less than $1 \mathrm{~m}$ wide and consist of predominantly calcite, dolomite, barite, with trace amounts of apatite, goyazite (including REE-rich end member florencite to calcium-rich end member crandallite), bastnaesite, monazite, pyrite, and quartz [44,82]. The Laughlin Peak carbonatites are light-REE enriched and contain $<1.6 \%$ total REE (Figure 6) [44].

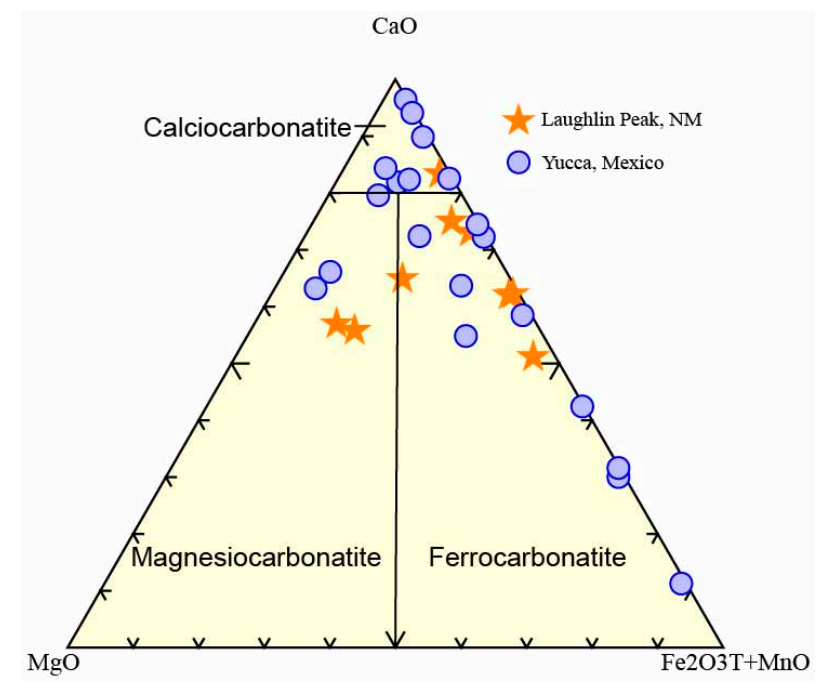

Figure 5. Chemical classification of carbonatites from Laughlin Peak and Mexico. Data from $[44,47,82]$.

The radioactive Th-REE-fluorite $( \pm \mathrm{U}, \mathrm{Nb})$ epithermal veins and breccias cut Cretaceous sedimentary rocks and Tertiary volcanic flows, dikes and sills, strike predominantly west to northwest with steep north or south dips, and are less than $600 \mathrm{~m}$ long and less than $1 \mathrm{~m}$ wide (Figure 3). Minor eat-west faults host veins locally. The veins are in linear zones of brecciated and fractured volcanic and intrusive igneous rocks. Crandallite, xenotime, thorite, and brookite are the predominant REE minerals in a gangue of quartz, calcite, feldspar, and trace amounts of barite, fluorite, rutile, zircon, pyrite, magnetite, and iron and manganese oxides [44,78,82]. The veins are light-REE enriched and contain $<1.2 \%$ total REE (Figure 6) and $<165 \mathrm{ppb} \mathrm{Au}([44,82]$, supplemental material). The veins contain as much as 2200 ppm F, 2000 ppm Ba, 532 ppm Nb, 172 ppm U, 75 ppm Ta, and 68 ppm Mo and low or no Te [44].

The radioactive breccia pipes are intrusive and consist of various iron and manganese oxides, angular to subrounded rock fragments (less than $0.6 \mathrm{~m}$ diameter) in a fine-grained siliceous and carbonate matrix of quartz and feldspar. Additional studies are needed to determine the relationship of the carbonate matrix to the carbonatites, if any. The breccia pipes are circular to oval shaped and six of the largest pipes range in size from 46 to $366 \mathrm{~m}$; smaller pipes have been delineated. Quartz, feldspar, and clay are the predominant minerals with trace amounts of gold, niobium rutile (?), pyrite, zircon, xenotime and churchite [44,82]. The total REE is less than 3017 ppm (Figure 6). The breccia pipes also contain as much as 5900 ppm F, 9050 ppm Ba, 535 ppm Nb, 54 ppm U and 82 ppb Au [44,82]. Core from the holes drilled in 1986 consists of predominantly grayish breccia cut by feldspar and iron oxide veinlets. Pyrite and marcasite were disseminated in portions of the core from drill hole 2. Only low concentrations of gold, silver, and tellurium were found in the core samples [44]. 


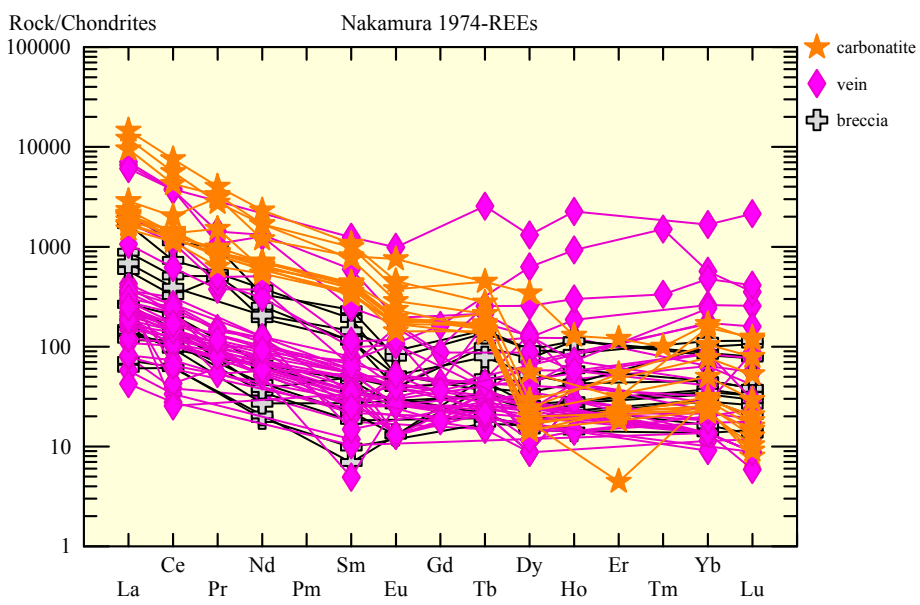

Figure 6. Chondrite-normalized [192] REE plots of veins, breccia pipes, and carbonatites from the Laughlin Peak district. Data are from $[44,82]$.

There is thorium, REE and possibly gold potential in the Laughlin Peak district, but additional drilling is required to more completely understand the mineral-resource potential. The best potential is in the carbonatites and Th-REE-fluorite $( \pm \mathrm{U}, \mathrm{Nb})$ epithermal veins and breccias. However, the Laughlin Peak district is not as faulted (Figure 3) as other GPM districts in New Mexico and this could prevent large, economic deposits from forming. Detailed studies on the mineralogy, geochronology, and paragenesis are still required in the Laughlin Peak district and should be completed before advanced exploration. Such studies will greatly enhance exploration efforts and subsequent processing, should economic deposits be found. Any sampling should include multi-element analyses, especially gold, thorium, REE, niobium, tungsten, and tellurium.

\subsection{Gallinas Mountains District}

The Gallinas Mountains (DIS092) are in northern Lincoln County where a series of alkaline-igneous laccoliths, dikes, and plugs (andesite, porphyritic latite, trachyte/syenite, and rhyolite) have intruded Permian sedimentary rocks (Figure 7) [99,108-110]. The Gallinas Mountains intrusions were emplaced at or just before the beginning of Rio Grande rift extension (27-39 Ma). The oldest intrusion is the porphyritic andesite, which has been dated as $39.74 \pm 0.058 \mathrm{Ma}\left({ }^{40} \mathrm{Ar} /{ }^{39} \mathrm{Ar}\right.$ methods $\left.[110,111]\right)$. The porphyritic latite is $28.178 \pm 0.04 \mathrm{Ma}$. The trachyte intrusion, the largest in the Gallinas Mountains and hosts most of the REE deposits [108], is slightly younger at $27.66 \pm 0.18$ to $29.232 \pm 0.097 \mathrm{Ma}$ $\left({ }^{40} \mathrm{Ar} /{ }^{39} \mathrm{Ar}\right.$ methods $\left.[110,111]\right)$. The syenite lenses within the trachyte are similar in age as the trachyte (26.51 \pm 0.15 to $29.77 \pm 0.16 \mathrm{Ma},{ }^{40} \mathrm{Ar} /{ }^{39} \mathrm{Ar}$ methods [110,111]). Brecciation, silicification, chloritization, and fenitization have altered the host rocks $[59,103,104,108]$. Only the trachyte and syenite have been fenitized and has been dated as $\sim 27$ to $\sim 30 \mathrm{Ma}\left({ }^{40} \mathrm{Ar} /{ }^{39} \mathrm{Ar}\right.$ methods $\left.[110,111]\right)$. Carbonatites are inferred at depth by the presence of fenitization, carbonatization of the breccias, presence of REE (especially bastnaesite) and fluorite, and similarity of the intrusive rocks and mineralization to areas with known carbonatites [108]. Associated igneous rocks (Figure 8a) in the Gallinas Mountains district are alkalic to alkali-calcic (Figure 8b; according to Frost and Frost [59]), predominantly ferroan, metaluminous to peraluminous and plot as A-type granites. The trachyte/syenite and latite samples plot within the within-plate granite (WPA) tectonic field of Pearce et al. ([57]; WPG), whereas the rhyolite samples plots within the volcanic-arc granite field (VAG). Trachyte/syenite and latite are probably related, but the rhyolite could be a separate magmatic event $[108,110]$. The associated igneous rocks exhibit typical light REE-enriched chondrite-normalized REE patterns of alkaline-igneous rocks with no europium anomaly (Figure 8c) (supplemental material).

The fenitization associated with the mineralization in the Gallinas Mountains is found as small, irregular zones that have not been mapped in detailed [104]. The trachyte/syenite, Proterozoic granite 
and granitic gneiss, and magmatic-hydrothermal breccia have been altered locally by two separate periods of fenitization; sodic followed by potassic fenitization. Sodic fenitization is characterized by replacement of feldspars and other minerals by albite. Potassic fenitization is characterized by replacement of feldspars, including older albite, and other minerals by K-feldspar [104].

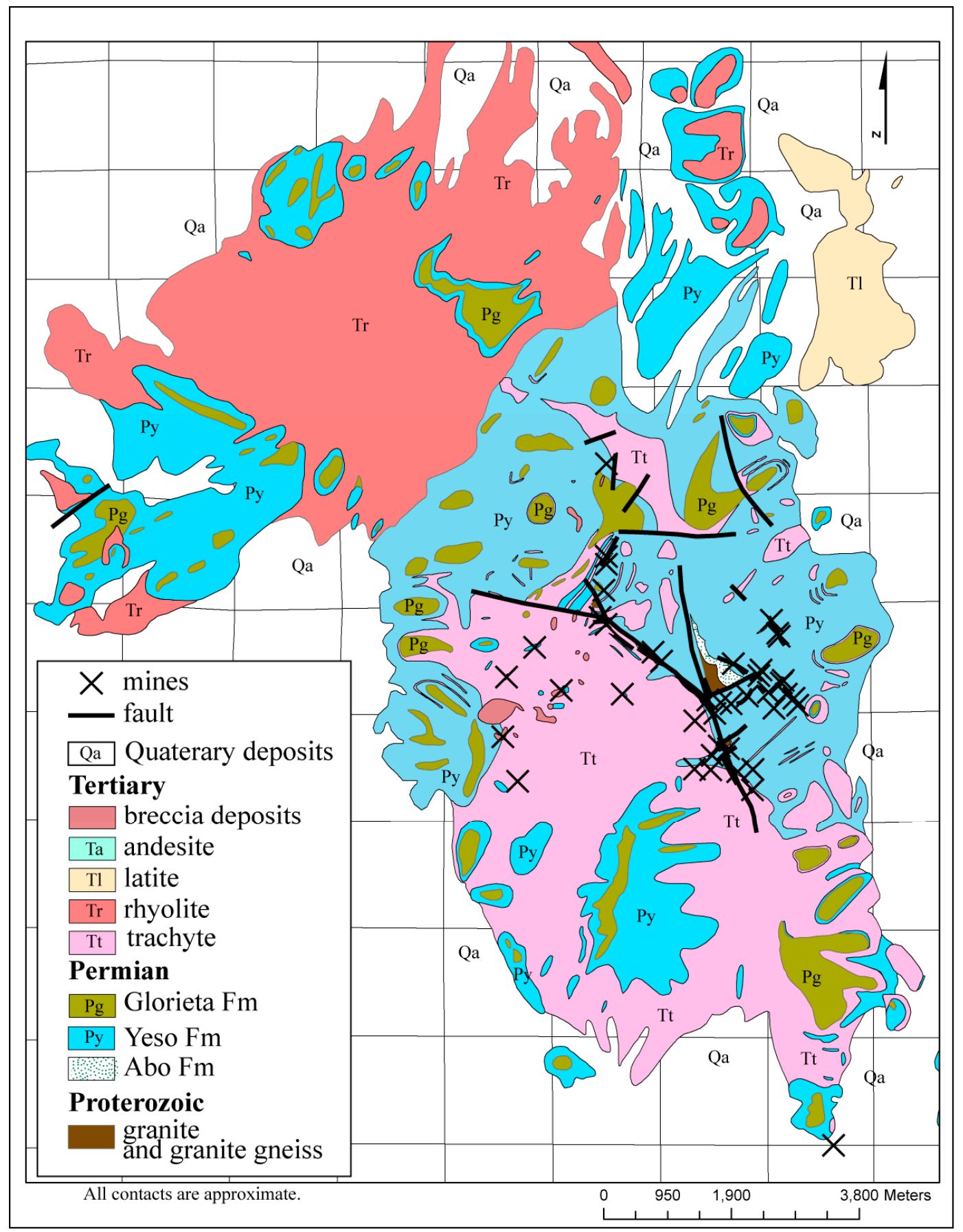

Figure 7. Geologic map of the Gallinas Mountains, Lincoln and Torrance Counties, New Mexico (modified from $[96,98,99,103,104,108]$ ). Fenites are not mapped due to small, irregular zones that would not show at this scale. Gray lines and numbers are township, range and section lines. 


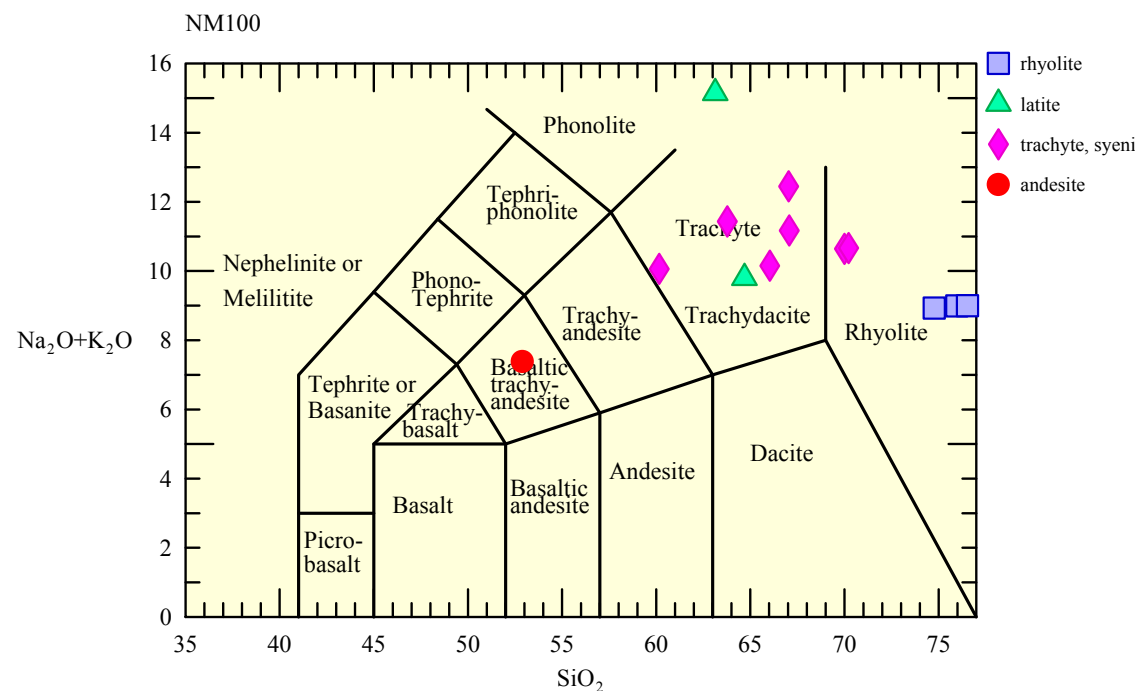

(a)

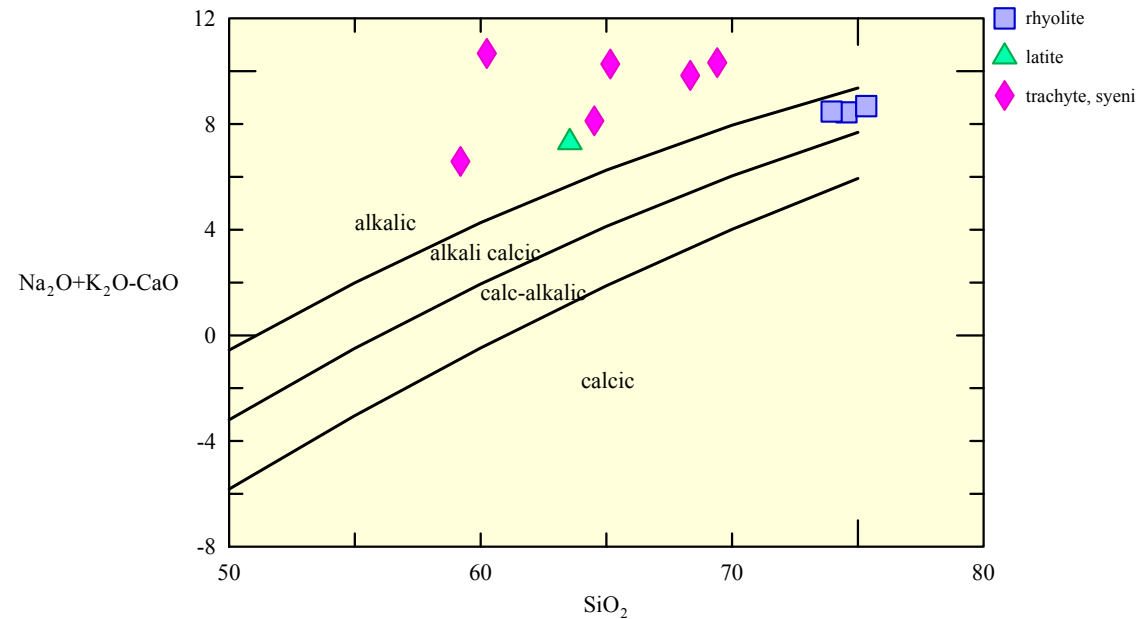

(b)

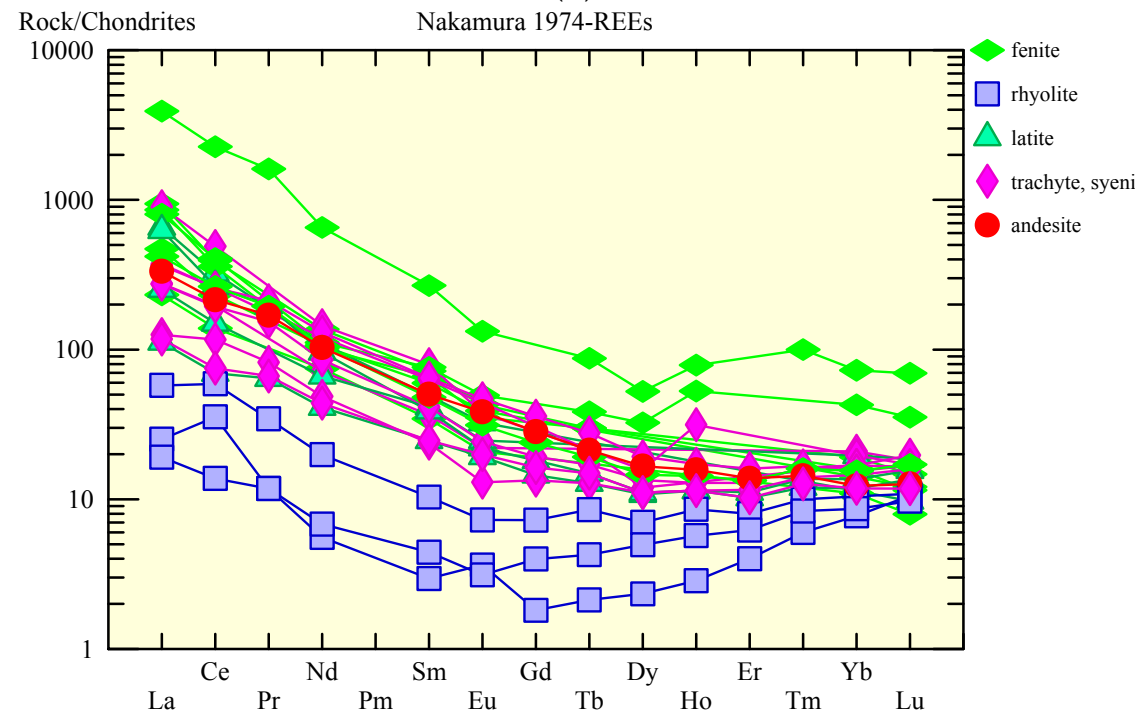

(c)

Figure 8. Chemical plots of igneous rocks from the Gallinas Mountains. Data are from 104, 108, and 110 (supplemental material). (a) is the TAS (Total Alkali Silica) diagram [190], (b) is alkaline to calc-alkalic diagram [59], and (c) is a chondrite-normalized REE plot [192]. 
The Red Cloud, Buckhorn, and Summit mining claims were established in 1881 in the Gallinas Mountains. Iron ore was produced from the American Iron and Red Cliff mines in 1942-1943 [92]. Fluorite was produced from the Red Cloud and Conqueror mines in 1951-1954. Approximately 142,000 lbs of bastnaesite, discovered in the district in 1943 [95,97], was produced from the Red Cloud mine in the 1950s. Exploration was by Phelps Dodge at the Rio Tinto mine in 1980, Molycorp, Inc. in 1980-1981 [104], and Canyon Resources, Hecla Mining Co., American Copper and Nickel, Inc., Romana Resources and Strategic Resources, Inc. in 1989-2015. Production is in Table 2.

Two types of mineral deposits in the Gallinas Mountains are associated with the trachyte/syenite: (1) Th-REE-fluorite $( \pm \mathrm{U}, \mathrm{Nb}$ ) epithermal veins and breccias (REE-F veins, Cu-REE-F veins, and REE-F breccia pipes) and (2) iron skarn deposits [108]. Cu-REE-F ( $\pm \mathrm{Pb}, \mathrm{Zn}, \mathrm{Ag})$ veins form center of the district, and are surrounded by REE-F veins (Figure 9). The magmatic-hydrothermal breccia pipe deposits form a belt partially surrounding the veins. Iron skarns formed at the top and edge of the trachyte/syenite body and are likely the earliest stage of mineralization. The iron skarns are probably related to the REE-F veins and breccias because they typically contain bastnaesite and fluorite and are similar in trace element geochemistry. The paragenesis is defined by four stages of brecciation and faulting with three stages of fluorite deposition (Figure 10). REE minerals were deposited during the 1st and 2nd stage of fluorite deposition. Most fenites are more enriched in REE than unaltered igneous rocks [104,108]. The mineralogy is diverse and includes fluorite, quartz, barite, pyrite, iron oxides and accessory bastnaesite, calcite, chalcedony, galena, bornite, chalcocite, pyromorphite, anglesite, chrysocolla, malachite, azurite and rare agardite (yttrium-arsenic oxide), mimetite, wulfenite, vanadinite, mottramite, and cerusite [98-101,104]. REE plots of the different types of deposits are shown in Figure 11. Geothermometric fluid-inclusion studies indicate a temperature of formation of $175-185^{\circ} \mathrm{C}[100,106,107]$. Trace-element compositions of fluorites from the Gallinas Mountains are characterized by relatively flat to light REE-enriched chondrite-normalized REE patterns, with no Eu anomaly [107]. The earliest generation of fluorite is similar to the composition of the trachyte/syenite. The fluorite samples plot in the hydrothermal and pegmatitic field [107], which is consistent with a magmatic-hydrothermal origin.

Resources amount to at least 537,000 short tons of 2.95\% total REE (not NI-43-101 compliant; [104,105]. Drilling is required to identify a better resource estimate. The fenites require detailed mapping and evaluation for potential REE.

Table 2. Minerals production from the Gallinas Mountains district, New Mexico.

\begin{tabular}{|c|c|c|c|c|c|}
\hline Mineral Produced & Mine Name & Years of Production & Amount (Short Tons) & Grade \% & Reference \\
\hline Copper & & 1909-1953 & 192.7 & & [108] \\
\hline Gold & & 1913-1955 & 6.58 ounces & & [108] \\
\hline Silver & & 1909-1955 & 23,723 ounces & & [108] \\
\hline Lead & & 1909-1055 & 863.4 & & [108] \\
\hline Zinc & & 1948-1953 & 8.7 & & [108] \\
\hline Iron ore & American & $1942-1943$ & 3944 & 55.7 & [92] \\
\hline \multirow[t]{3}{*}{ Fluorite } & All American & & 129 & & [195] \\
\hline & Conqueror (Rio Tinto) & & 300 & & [195] \\
\hline & Red Cloud & & 1000 & & [195] \\
\hline \multirow[t]{2}{*}{ Bastnaesite } & Conqueror No. 9 & 1954-1955 & 60 & & [94] \\
\hline & Conqueror No. 10 & 1956 & 11 & & [94] \\
\hline
\end{tabular}




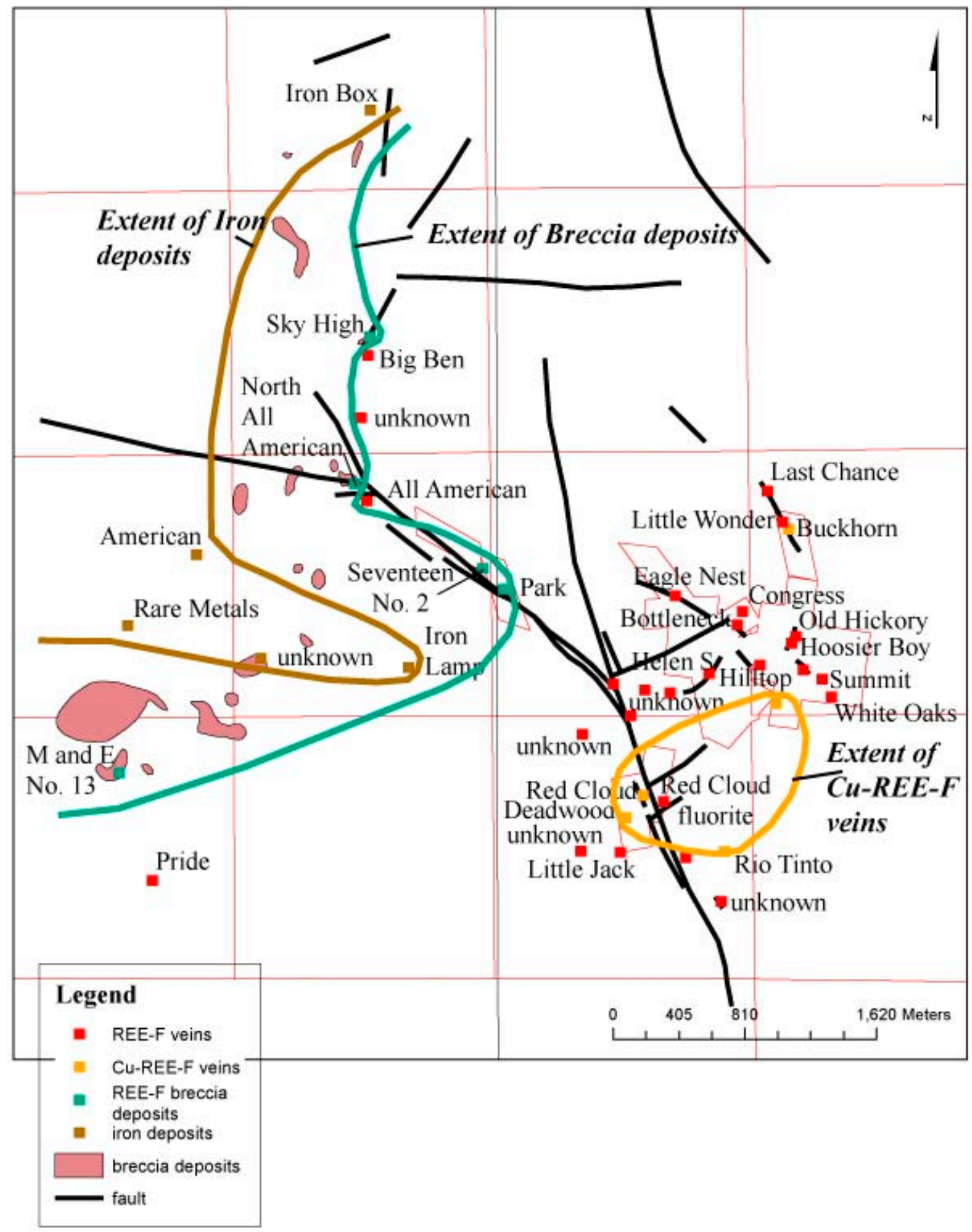

Figure 9. Mineral zoning in the Gallinas Mountains, Lincoln County, New Mexico, based upon predominant mineralogy and chemistry of the known deposits [108]. Fenites are not mapped due to small, irregular zones that would not show at this scale. 


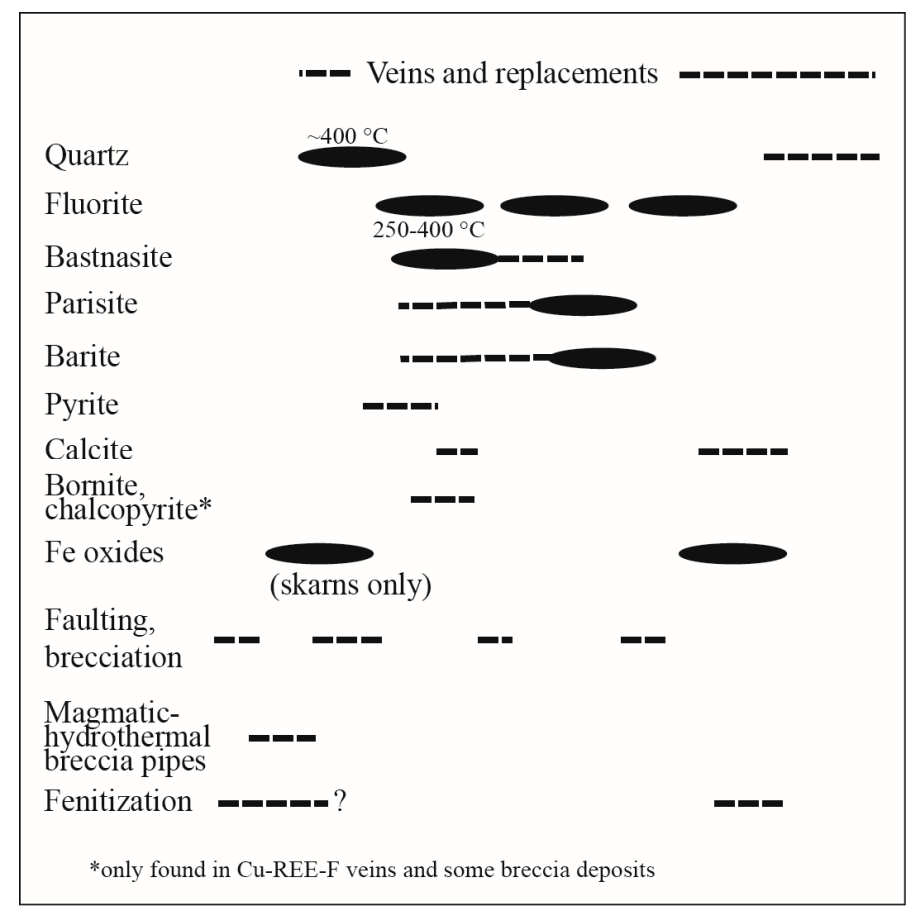

Figure 10. Simplified paragenesis of the REE deposits in the Gallinas Mountains ([108], modified from $[99,104,106])$. Temperature estimates are from [106].

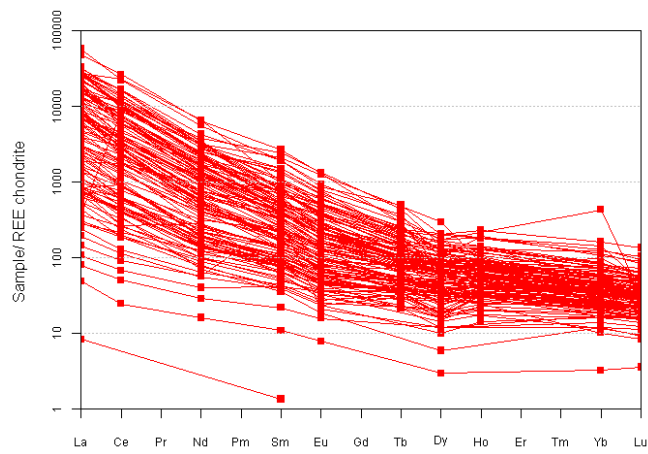

(a)

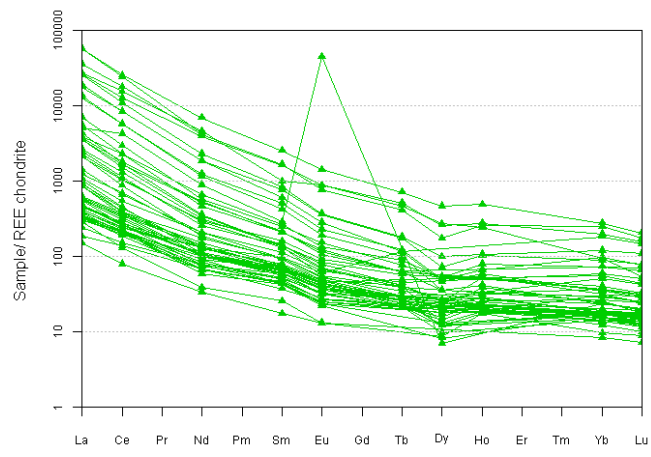

(c)

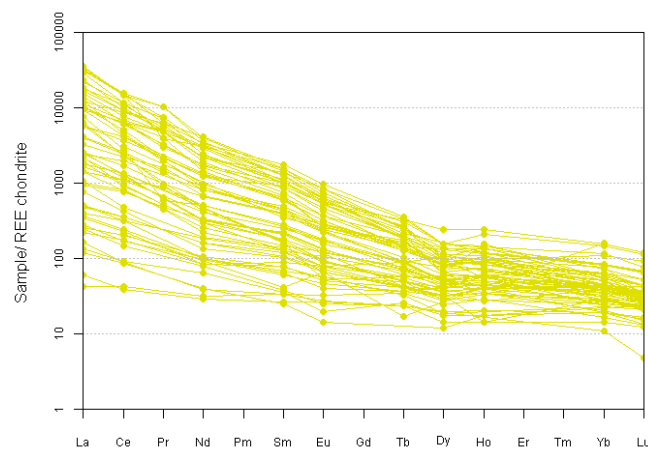

(b)

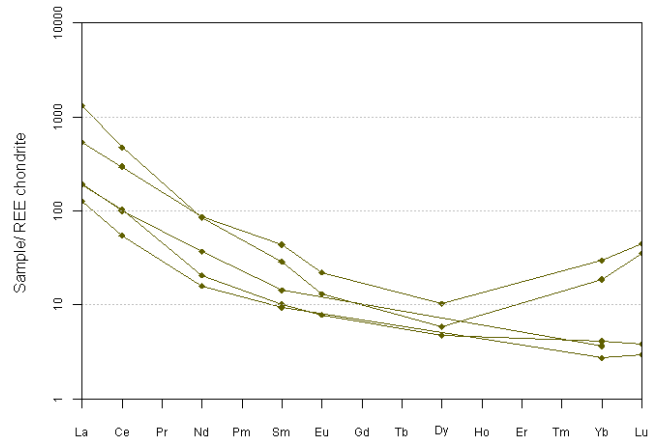

(d)

Figure 11. Chondrite-normalized REE plots [192] (supplemental material) of mineralized samples from the Gallinas Mountains. Data are from 104 and 108. Note the similarity in REE patterns between the different deposit types. (a) REE-F veins (131 samples); (b) Cu-REE-F veins (65 samples); (c) Breccia pipe deposits (58 samples); (d) iron skarns (6 samples). 


\subsection{Capitan Mountains District}

The Capitan Mountains district (DIS091) is associated with the largest exposed Tertiary intrusion in New Mexico, the Capitan pluton, which lies along the east-west trending Capitan lineament (Figure 2) $[43,124]$. The Capitan Mountains pluton was emplaced during the beginning of Rio Grande rift extension ( $\sim 29 \mathrm{Ma})$. The best estimate of the age of the pluton is $28.8 \mathrm{Ma}$, based on ${ }^{40} \mathrm{Ar} /{ }^{39} \mathrm{Ar}$ dating of adularia that is associated with emplacement of the pluton $[43,128]$. The east-west trend of the Capitan pluton reflects the influence the Capitan lineament had on controlling its emplacement. The Capitan pluton hosts Th-REE-fluorite $( \pm \mathrm{U}, \mathrm{Nb})$ epithermal veins and breccias, whereas the Fe skarns and veins and manganese veins and replacement deposits are in limestones adjacent to the Capitan pluton.

The Capitan pluton is a calc-alkaline to subalkaline granite that consists of three textural zones: uppermost granophyric ( 200 m thick), intermediate aplitic ( 200 m), and lower porphyritic $(>1000 \mathrm{~m})$ zones (Figure 12). The textural zones are chemically distinct (Figure 13a-c) suggesting that the zones are related to magmatic and chemical processes, not simple cooling [124]. Chemically the Capitan pluton is ferroan to magnesian, peralkaline to peraluminous, alkalic to calc-alkalic (Figure 13b), and

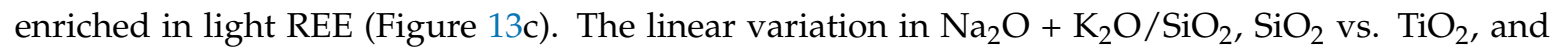
$\mathrm{SiO}_{2}$ vs. $\mathrm{Zr} / \mathrm{TiO}_{2}$, and various major elements confirm that the textural zones are comagmatic [124] (Supplemental Material).

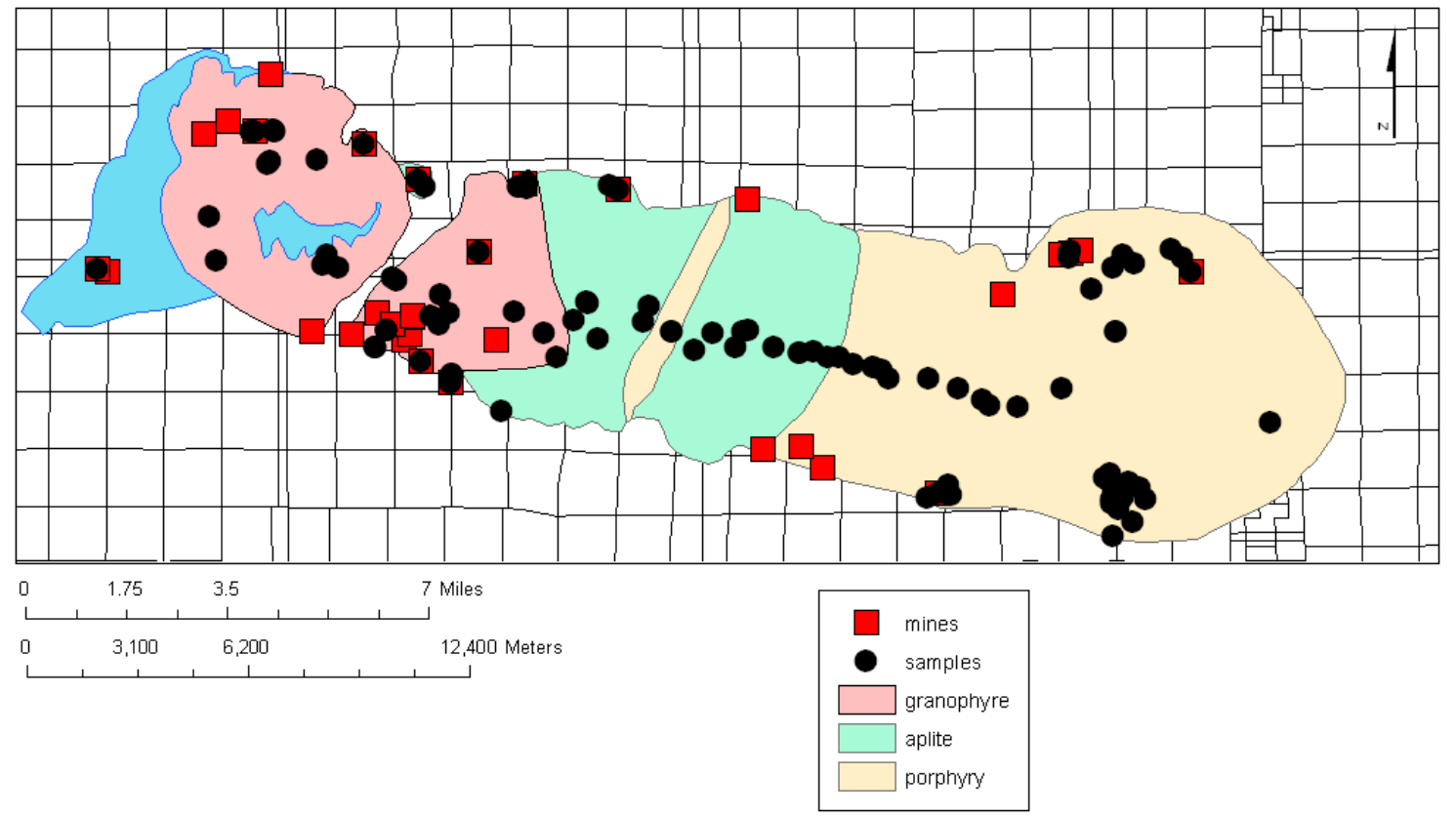

Figure 12. Geologic map of the Capitan Mountains showing the zonation of the Capitan pluton distribution of samples, mines and prospects. Mapping by the author in 1989-1991. The blue zones are Permian sedimentary rocks. The surrounding units (white) are Cretaceous, Permian, and Quaternary sedimentary rocks. Gray lines and numbers are township, range and section lines.

Fine-grained texture, porous zones (i.e., open space fissures and miarolitic cavities) in the granophyric and aplitic zones, and porphyritic texture in the center all suggest a rapid, shallow crystallization of the magma [124,128]. Rare exposures along the northern and southern longitudinal contacts of the pluton with the older Permian sedimentary rocks are slightly dipping away from the pluton. The western and eastern contacts between the pluton and sedimentary rocks dip steeply away from the pluton to vertical. Flat-lying roof pendants of Permian limestone and sills on the western end suggest the pluton is a laccolith or batholith [124]. The sedimentary roof pendants of Permian 
limestone are found west of Capitan Pass (Figure 12). Stoping and assimilation of the sedimentary rocks by the pluton is lacking.

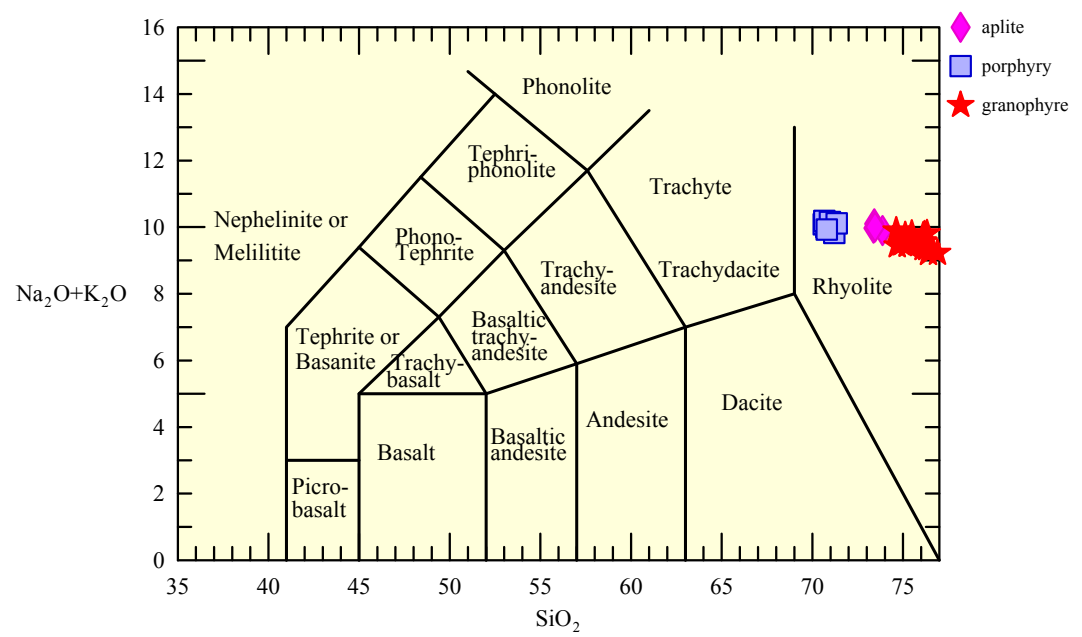

(a)

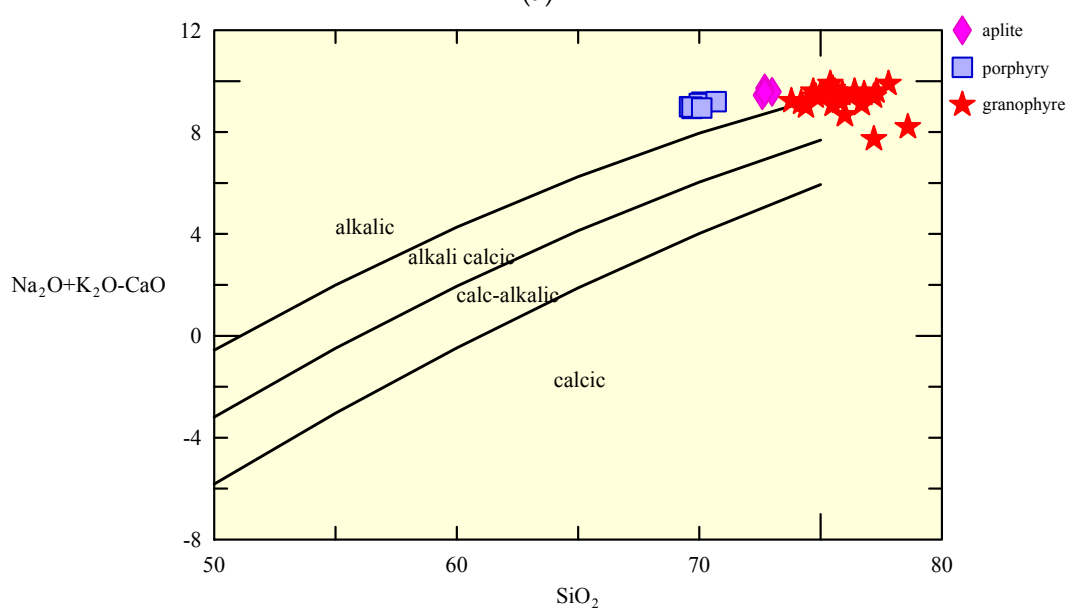

(b)

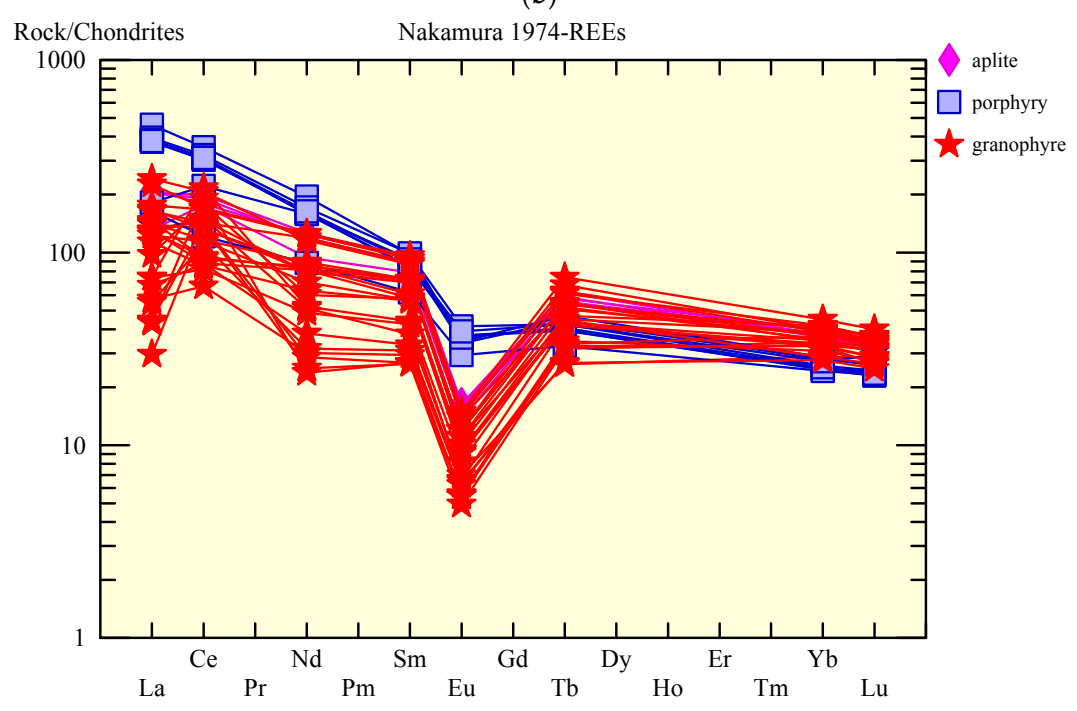

(c)

Figure 13. Chemical plots REE plots of igneous rocks from the Capitan Mountains. Data are from [124,128] (supplemental material). (a) is the TAS (Total Alkali Silica) diagram [190], (b) is alkaline to calc-alkalic diagram [59], and (c) is a chondrite-normalized REE plot [192]. 
The Th-REE-fluorite $( \pm \mathrm{U}, \mathrm{Nb})$ epithermal veins and breccias are exclusively in the granophyric and aplitic zones along the western end of the pluton (Figure 12) and contain trace amounts of gold. Iron skarn and vein deposits are found along the western and northeastern portions of the pluton. Manganese deposits are found along the northeastern portion of the pluton. The Th-REE-fluorite $( \pm \mathrm{U}, \mathrm{Nb})$ epithermal veins and breccias contain quartz, fluorite, adularia, hematite, calcite, fluorite, titanite, allanite, thorite, chlorite, and clay minerals [46]. They probably formed from magmatic fluids as indicated by very highly saline (as much as $80 \%$ eq. $\mathrm{NaCl}$ ) fluid inclusions with homogenization temperatures of 500-600 ${ }^{\circ} \mathrm{C}[46,120-123,126-128]$. The fluid inclusions contain $\mathrm{Na}, \mathrm{K}, \mathrm{Ca}, \mathrm{Cl}, \mathrm{S}, \mathrm{Fe}, \mathrm{Mn}$, $\mathrm{Zn}$, and light REE as determined from crush-leached samples of quartz and fluorite $[123,126]$. Similar fluid inclusions are found throughout the granitic rocks of the Capitan pluton [127]. Porous zones are characterized by open spaces, bubble-like features, miarolitic cavities, and fissures along fractures within the granite; are locally associated with Th-REE-fluorite $( \pm \mathrm{U}, \mathrm{Nb})$ epithermal veins and breccias; are found only in the granophyric zone; and are interpreted as pathways that allowed fluids to move through the magma into the outer zones of the pluton, forming the REE-Th-U ( $\pm \mathrm{Au}$ ) veins [128].

Three samples of the Th-REE-fluorite $( \pm \mathrm{U}, \mathrm{Nb})$ epithermal veins and breccias contain higher concentrations of REE than the unaltered/unmineralized Capitan granites and all vein samples are elevated in light REE (Figure 14). One sample from the McCory prospect (\#1784) contained $8133 \mathrm{ppm}$ total REE (Figure 14). A sample from the Fuzzy Nut prospect contained 1110 ppm Th [119]. Staatz [196] reported samples contained less than 0.01 to $1.12 \%$ total REE. Alteration of adjacent rocks to the veins includes minor silicification, hematization, and sericitization. A simplified paragenesis of the REE deposits in the Capitan Mountains is in Figure 15.

The Capitan Mountains REE deposits lie adjacent to a wilderness area and have not been examined for minerals resources, because of potential environmental concerns and permitting issues. However, the Th-REE-fluorite $( \pm \mathrm{U}, \mathrm{Nb})$ epithermal veins and breccias require detailed mapping and sampling to properly assess their economic potential.

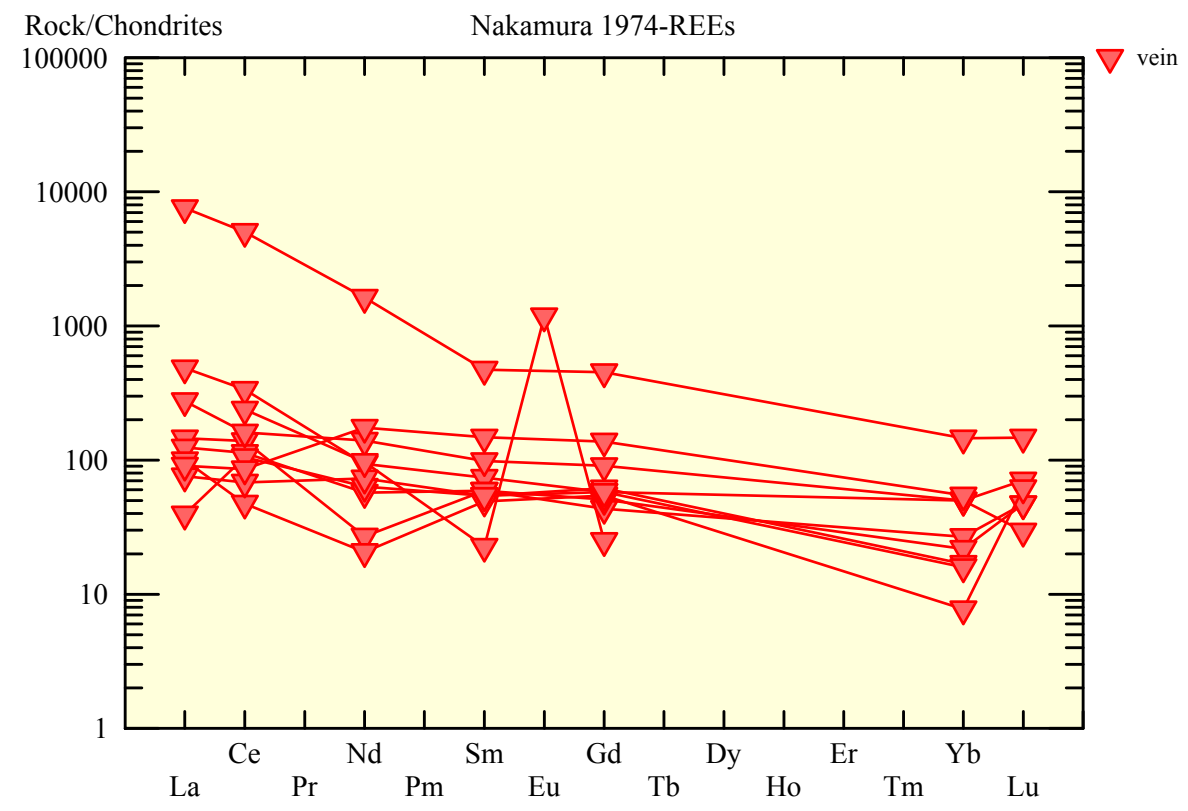

Figure 14. Chondrite-normalized [192] REE plots of Th-REE-fluorite $( \pm \mathrm{U}, \mathrm{Nb})$ epithermal veins and breccias in the Capitan Mountains (supplemental material). Eu was not analyzed in most vein samples, thus the significance of the Eu anomaly is unknown until more analyses are obtained. Note the samples have flat to slightly enriched light REE. 


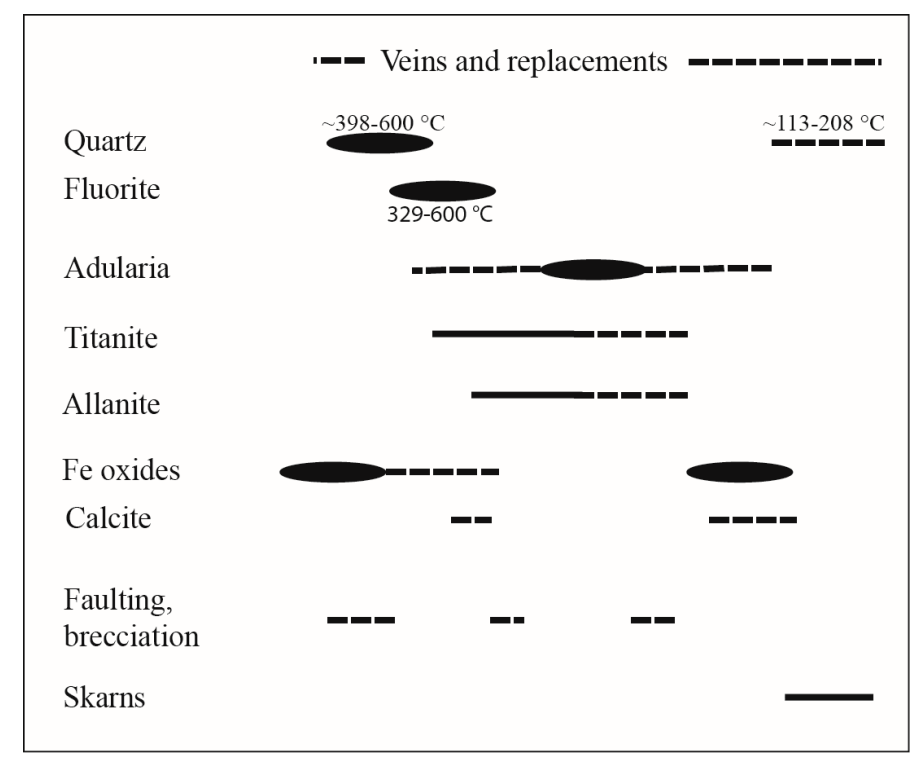

Figure 15. Simplified paragenesis of the REE vein deposits in the Capitan Mountains (modified from [121]). Temperature estimates from [121].

\subsection{Cornudas Mountains District}

The Cornudas Mountains (DIS128) are in southern Otero County, New Mexico and northern Huspeth County, Texas (Figure 2) and form the northern extent of the Trans-Pecos alkaline magmatic province. The Cornudas Mountains pluton was emplaced at or during the beginning of Rio Grande rift extension ( 33-36 Ma). The Cornudas Mountains consist of 10 larger sills, plugs, and laccoliths and smaller dikes and plugs (Table 3, Figure 16) that intrude relatively flat-lying limestones and other sedimentary rocks of the Hueco Limestone and Bone Spring Limestone (Permian). Other dikes, sills, and plugs are buried by sedimentary cover, as indicated by subsurface drilling [197], geophysical surveys, and structural anomalies (i.e., folds, synclines, faults) in the overlying sedimentary rocks. Associated igneous rocks (Figure 17a) in the Cornudas Mountains are alkaline, alkali (Figure 17b; according to Frost and Frost [59]), ferroan, metaluminous to peralkaline and plot as A-type granites and WPG (within-plate granites according to Pearce et al. [57]) (supplemental material). The host igneous rocks exhibit typical light REE-enriched chondrite-normalized REE patterns of alkaline-igneous rocks with no europium anomaly (Figure 17c). The Cornudas Mountains have been examined for potential deposits of Th-REE-fluorite ( $\pm \mathrm{U}, \mathrm{Nb}$ ) epithermal veins and breccias (with associated $\mathrm{REE}, \mathrm{Au}, \mathrm{Ag}$ ) and nepheline syenite as specialty, dimension and crushed stone [167-170]; but there has been no production except for test shipments of nepheline syenite for use as sand-blasting material in 1995.

Table 3. Description of igneous intrusive bodies within the Cornudas Mountains. Bodies shown in Figure 16.

\begin{tabular}{|c|c|c|c|c|}
\hline Name & Form & Predominant Lithology & Age Ma & References \\
\hline Alamo Mountain & $\begin{array}{l}\text { phonolite, foliated } \\
\text { porphyritic nepheline } \\
\text { syenite }\end{array}$ & discordant sheet or sill & $36.8 \pm 0.6(\mathrm{~K} /$ Ar on biotite $)$ & {$[165,166]$} \\
\hline Flat Top Mountain & $\begin{array}{c}\text { phonolite, augite syenite } \\
\text { dike }\end{array}$ & sill & - & [165] \\
\hline Cornudas Mountain & $\begin{array}{l}\text { quartz-bearing syenite, } \\
\text { syenite, trachyte }\end{array}$ & plug or laccolith & $34.6 \pm 1.5$ (K/Ar on biotite) & {$[165,166]$} \\
\hline
\end{tabular}


Table 3. Cont.

\begin{tabular}{ccccc}
\hline Name & Form & Predominant Lithology & Age Ma & References \\
\hline $\begin{array}{c}\text { San Antonio Mountain } \\
\text { Wind Mountain) }\end{array}$ & nepheline syenite & laccolith & - & pepheline syenite \\
\hline Chatfield Mountain & phonolite & plug or laccolith & $33.0 \pm 1.4($ K/Ar on biotite) & sill \\
\hline Black Mountain & $\begin{array}{c}\text { porphyritic nepheline } \\
\text { syenite }\end{array}$ & sill & [165,166] & [165] \\
\hline Washburn Mountain & $\begin{array}{c}\text { porphyritic nepheline } \\
\text { syenite }\end{array}$ & sill & [165] \\
\hline Unnamed hill & $\begin{array}{c}\text { nepheline-bearing augite } \\
\text { syenite }\end{array}$ & plug & $36.8 \pm 0.6($ K/Ar on biotite)
\end{tabular}

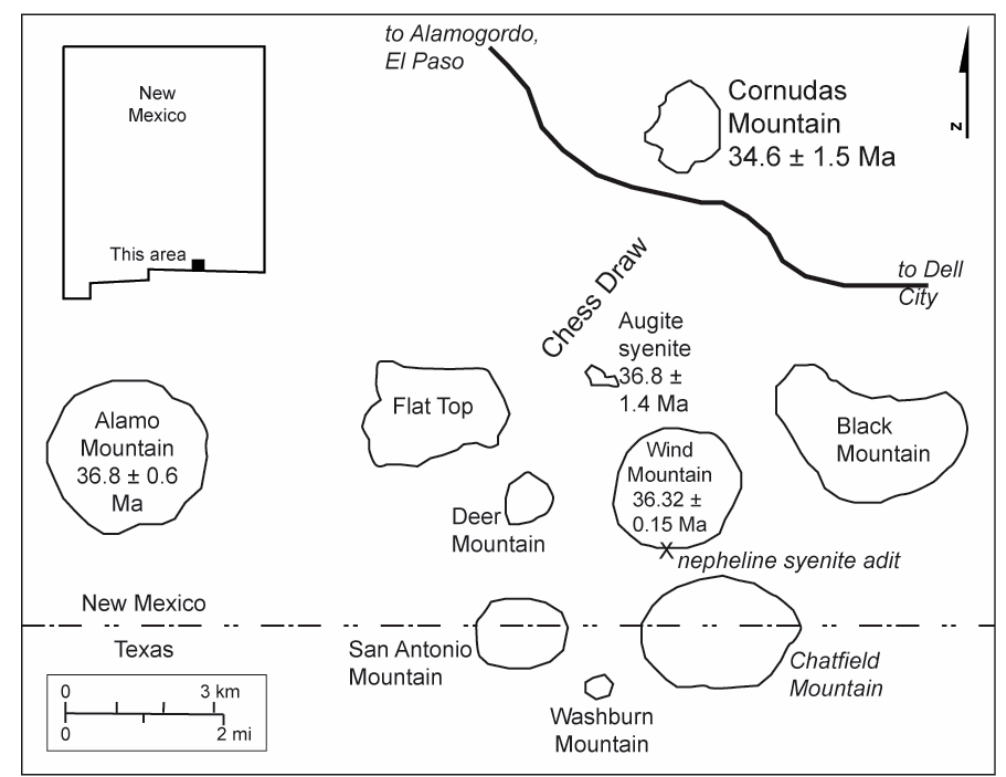

Figure 16. Locations of various igneous plutons in the Cornudas Mountains, New Mexico. See Table 3 for a summary of their lithology and age.

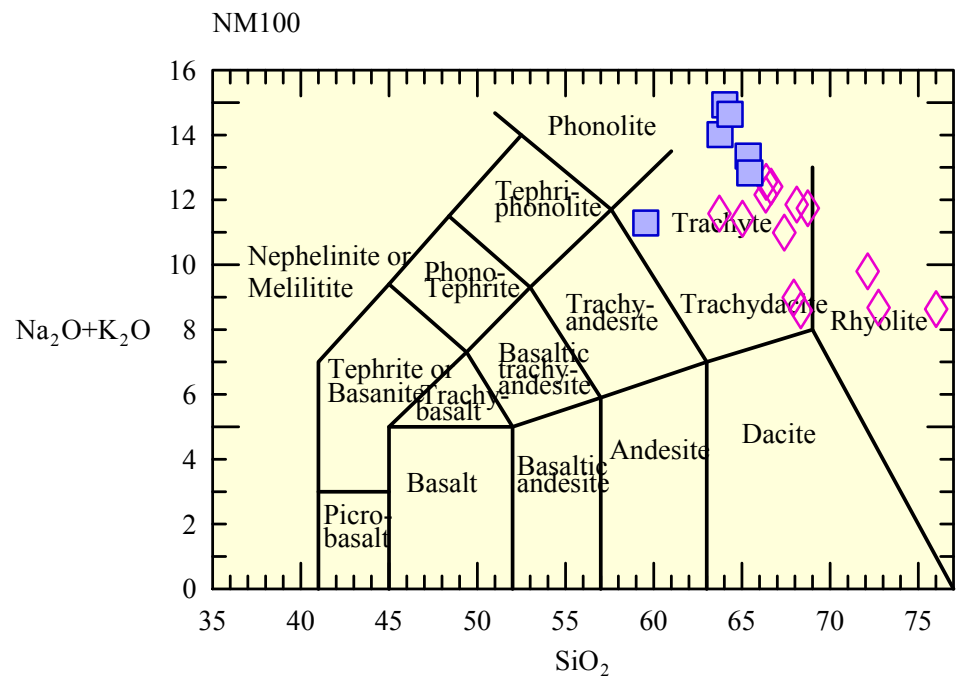

(a)

Figure 17. Cont. 


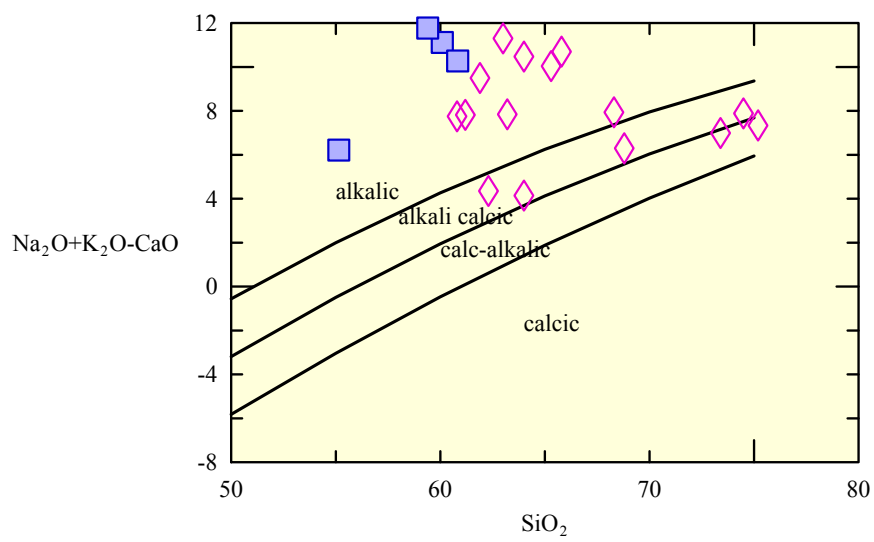

(b)

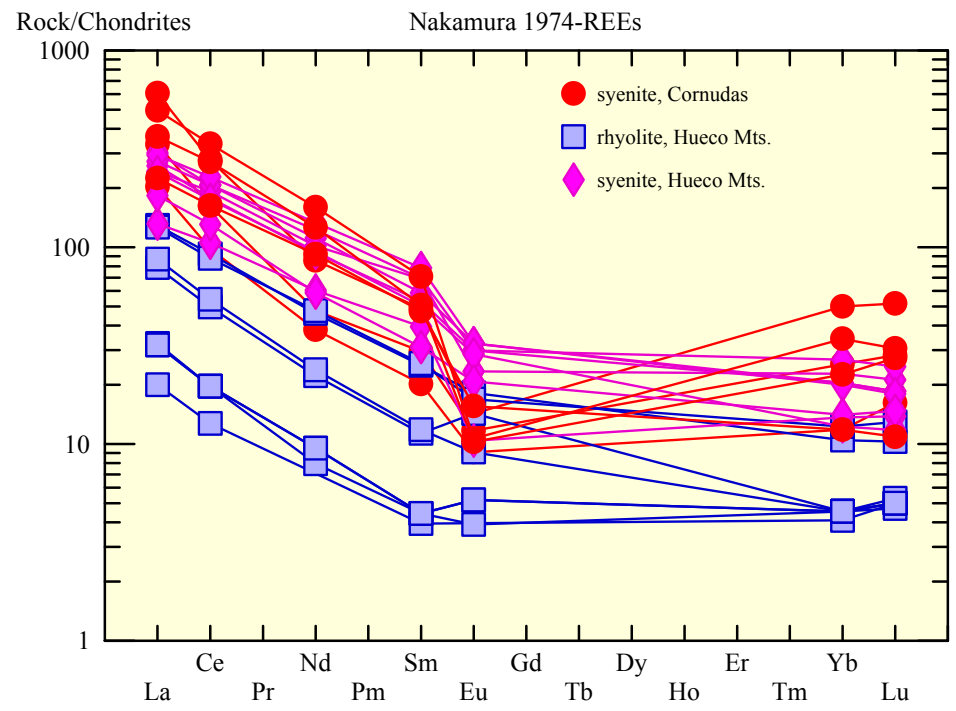

(c)

Figure 17. Chemical plots of igneous rocks from the Cornudas and Hueco Mountains. Data are from ([28,169,171,172], supplemental material). (a) is the TAS (Total Alkali Silica) diagram [190], (b) is alkaline to calc-alkalic diagram [59], and (c) is a chondrite-normalized REE plot [192].

In the 1950s, prospectors located several areas of anomalously high radioactivity in the Cornudas Mountains and attributed it to the presence of uranium. Shallow prospect pits were dug on many of the claims in the area; but, assay results were low and the claims were later dropped with no production. In 1956, the U.S. Atomic Energy Commission examined the area to evaluate the potential for uranium [162]. No further work was recommended. Beryllium was first reported from the Cornudas Mountains during the 1940s [163]. A few companies have examined the Cornudas Mountains unsuccessfully for high concentrations of REE, niobium, zirconium, and titanium. In 1984, Leonard Minerals Co. in conjunction with U.S. Borax Corp. conducted an exploration program for REE, niobium, and zirconium. Mapping, sampling, and drilling in the Chess Draw area failed to discover any significant mineralized zones (NMBGMR files). In 1992-1993, Addwest Minerals, Inc. examined the Wind Mountain nepheline syenite laccolith for use in glass and ceramics and delineated 10 million short tons of resources $[168,169]$. Geovic Mining Corp. acquired property in the Cornudas Mountains about 2010, and conducted a sampling and drilling program. Results are unknown.

The Wind Mountain laccolith consists of three major mineralogical and textural zones (Figure 18) [168,169]. The laccolith is typically gray to cream colored and weathers to darker colors. Accessory minerals form dark-colored aggregates dispersed throughout the rock. The margin of the laccolith is foliated. The foliation dips steeply away from the center of the intrusive body. Chemical 
variations among the individual map units within the laccolith cannot be readily discerned by utilizing major element analyses [168,169]. These chemical analyses of the Wind Mountain laccolith suggests that the zonation appears to be controlled by crystal fractionation, volatile separation, and cooling history, not different pulses of magma $[168,169]$. Feldspar crystallization under initially subsolvus conditions can account for most of the variations in the zones. The feldspar-rich solid forms at or migrates towards the top of the magma chamber and forms a capping syenite. Differential cooling of the magma resulted in the textural variations at Wind Mountain.

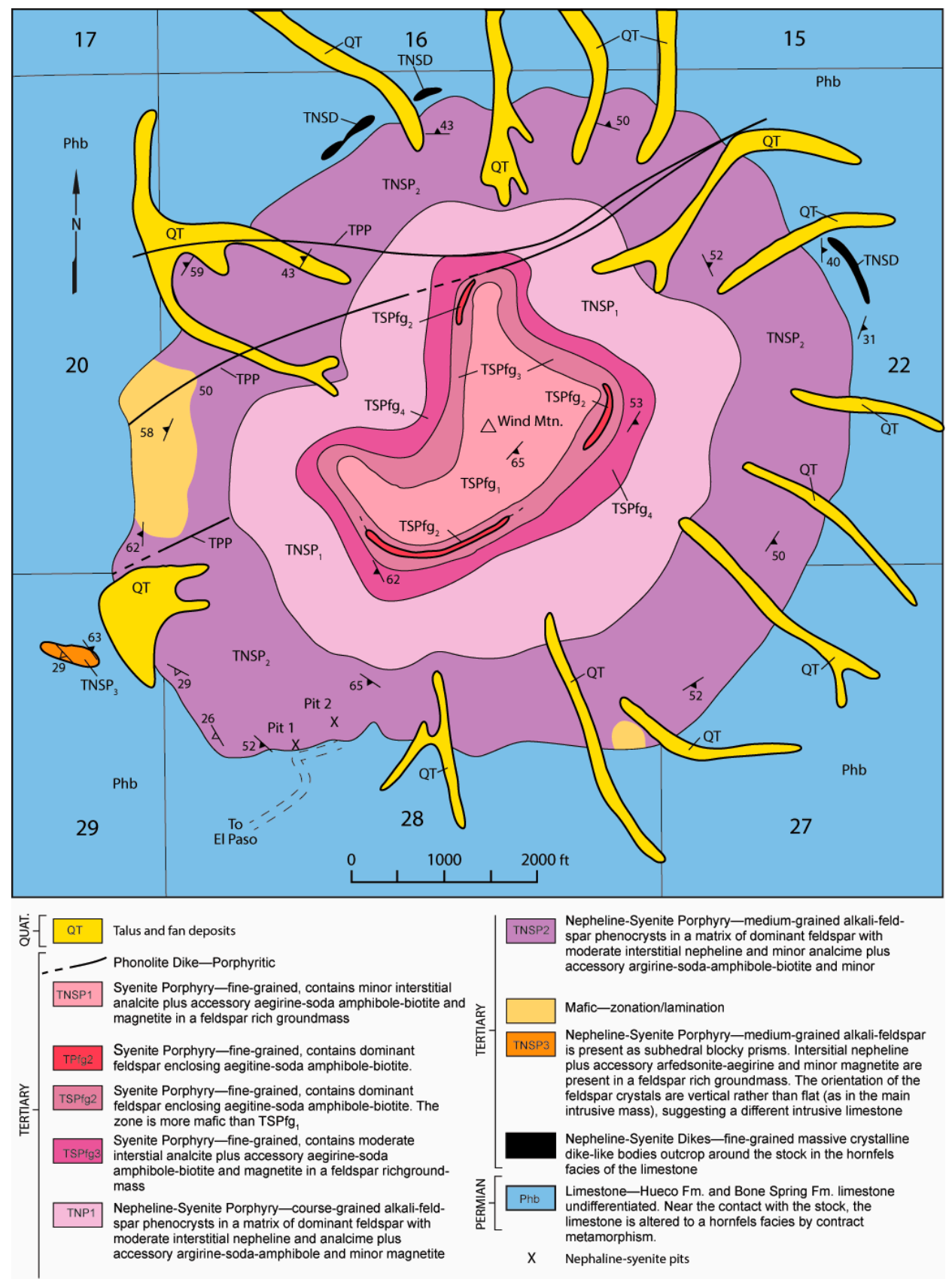

Figure 18. Geologic map of Wind Mountain showing geological zonation [169]. See Figure 16 for location of Wind Mountain in the Cornudas Mountains. Mapping by P. Graeah in 1992.

In the Chess Draw area (northwest of Wind Mountain), a few radioactive dikes and Th-REE-fluorite $( \pm \mathrm{U}, \mathrm{Nb})$ epithermal veins and breccias have been examined for mineral-resource potential. Uranium 
and thorium are found disseminated within the dikes, veins, and breccias but are not economic. Assays ranged from 0 to $0.8 \% \mathrm{U}_{3} \mathrm{O}_{8}$ [162] and 13-351 ppm Th [168]. Past exploration for Be in the Cornudas Mountains was inconclusive. A few samples assayed as much as $0.2 \% \mathrm{BeO}$ [163]. Beryllium is found in feldspar, nepheline, aegirine, and eudialite within dikes, sills, and laccoliths in the Cornudas Mountains; no Be minerals have been identified. U.S. Borax sampled and drilled in the Chess Draw area, but their assays were low (Figure 19; up to $0.06 \%$ total REE oxides, $10-1400 \mathrm{ppm} \mathrm{Nb}, 10-3000 \mathrm{ppm}$ $\mathrm{Zr}, 230-13,000 \mathrm{ppm}$ F). An analysis of a dike [17,18] contained 1235 ppm Ce, 700 ppm La, 270 ppm $\mathrm{Nd}$, and $242 \mathrm{ppm} \mathrm{Y}$ (sample \#7368). Other analyses [168] also are low and subeconomic: as much as 3790 ppm total REE, 2332 ppm Nb, 92 ppm Be, and 3137 ppm F. Reconnaissance mapping of the area reveals no additional deposits and the limited geophysical surveys are inconclusive [170], but detailed mapping of the areas surrounding Wind Mountain is required to properly assess the economic potential. Still, additional mineral-resource potential in the Cornudas Mountains is probably limited $[168,170]$, but detailed geochemical, geophysical, and other exploration techniques are required to properly evaluate this area, especially in dikes and along intrusive contacts with the limestones.

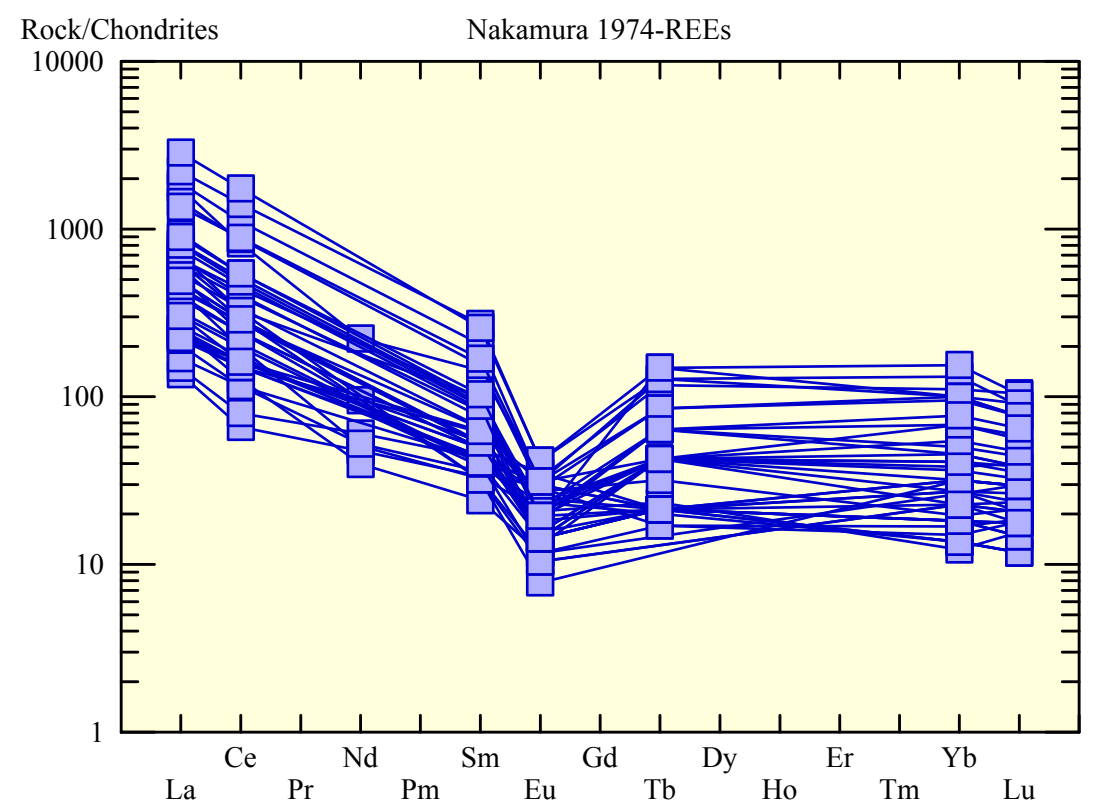

Figure 19. Chondrite-normalized [192] REE plots of mineralized veins and breccias from the Cornudas Mountains. Data are from ([168], supplemental material).

\subsection{Sierra Blanca (Round Top Mountain)}

Sierra Blanca, Texas is south of the Cornudas and Hueco Mountains, New Mexico, and is part of the Trans-Pecos alkaline magmatic province (Figures 1 and 20). Sierra Blanca consists of five rhyolite domes or laccoliths (Round Top, Little Round Top, Little Blanca, Sierra Blanca and Triple Hill) that host peralkaline intrusion-related REE deposits [41]. The rhyolites are peralkaline to peraluminous [198], 36.2 Ma [166], and enriched in $\mathrm{Li}, \mathrm{Be}, \mathrm{F}, \mathrm{Zn}, \mathrm{Rb}, \mathrm{Y}, \mathrm{Zr}, \mathrm{Nb}, \mathrm{Sn}, \mathrm{REE}$, and Th [175,176]. Fluorspar replacement bodies, enriched in $\mathrm{Be}, \mathrm{Zr}, \mathrm{REE}$, and other elements are found the contacts of the laccoliths and Cretaceous limestones [173-176,183,184]. 


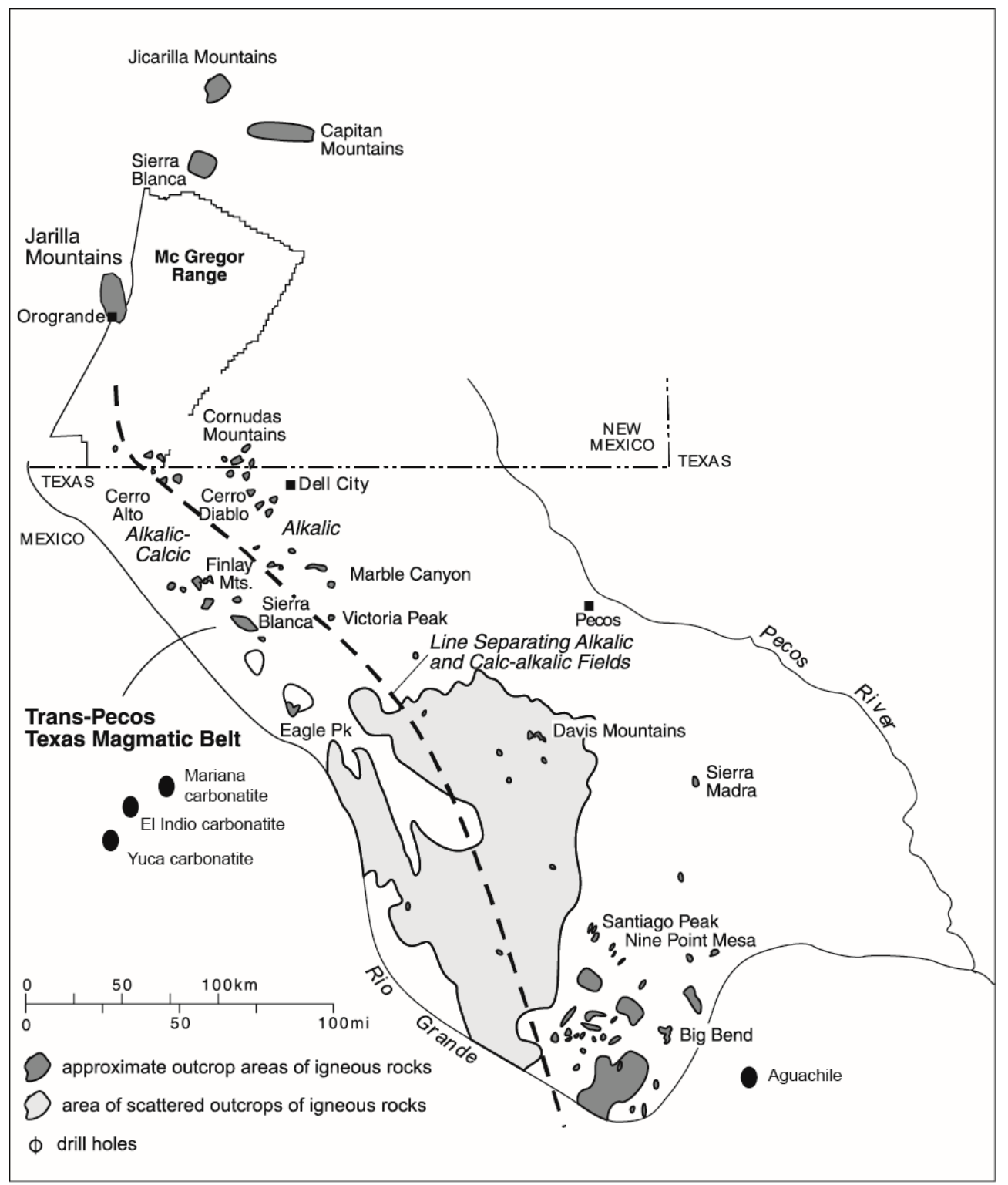

Figure 20. Trans-Pecos magmatic province, New Mexico, Texas, and eastern Mexico (modified from $[165,179])$.

In 1984-1985, Cabot Corporation drilled and found Be-F veins and replacements of limestone adjacent to the rhyolite dome at Round Top Mountain. A 38-m decline was constructed by Cyprus Sierra Blanca, Inc., successor to Cabot Corporation, and the West End structure was reported to contain 300,000 short tons of $1.9 \% \mathrm{BeO}$ at a cutoff grade of $0.5 \%$. The entire project area was reported to contain 25 million pounds of BeO [180]. In 1993, Cyprus merged with Amax becoming Cyprus-Amax, which subsequently merged with Phelps Dodge in 1999. Grades exceeding $1 \% \mathrm{U}$ are found in the deposits. In 2007, Standard Silver Corp. acquired the Round Top Mountain deposits and in 2011, changed their name to Texas Rare Earth Resources Corp. The deposit contains an estimated 231.0 Mt of rare-earth mineral resources at the Measured level, with an average grade of $0.06 \mathrm{wt} \%$ total rare-earth oxide (TREO), 298.0 Mt of resources at the Indicated level, with an average grade of $0.06 \%$ TREO, and an estimated 377.0 Mt of resources at the Inferred level, with an average grade of $0.06 \%$ TREO.

The Round Top Mountain rhyolite intruded Cretaceous limestone and was subsequently hydrothermally altered (fluoritization, kaolinization). The rhyolite is gray, fine grained with visible local flow banding and contains a variety of minerals [198]. Nearby Sierra Blanca rhyolite 
is $36.2 \pm 0.6 \mathrm{Ma}(\mathrm{K} / \mathrm{Ar}$, biotite, 166) and Round Top Mountain rhyolite is likely similar in age. The rhyolite domes at Sierra Blanca are enriched in $\mathrm{Li}, \mathrm{Be}, \mathrm{F}, \mathrm{Zn}, \mathrm{Rb}, \mathrm{Y}, \mathrm{Zr}, \mathrm{Nb}, \mathrm{Sn}, \mathrm{REE}$, and Th and depleted in $\mathrm{Mg}, \mathrm{Ca}$, and Ti relative to typical calc-alkaline rhyolites [175]. Chemically, the rhyolite is alkaline, peralkaline to peraluminous and similar to topaz-bearing rhyolites. The Sierra Blanca pluton was emplaced just before the beginning of Rio Grande rift extension ( $36 \mathrm{Ma})$. Chondrite-normalized enriched REE patterns exhibit depleted light REE patterns with a negative Eu anomaly (Figure 21). REE minerals include Y-bearing fluorite, bastnaesite, xenotime, and fluocerite $[184,186]$. Beryllium occurs mostly in contact metasomatic veins and replacements in limestones as behoite $\left(\mathrm{Be}(\mathrm{OH})_{2}\right)$, with lesser amounts of berborite $\left(\mathrm{Be}_{2}\left(\mathrm{BO}_{3}\right)(\mathrm{OH}, \mathrm{F}) \cdot \mathrm{H}_{2} \mathrm{O}\right)$, bertrandite, chrysoberyl, phenakite, fluorite and garnet $[175,176,179]$. The mineralization appears to be formed by high-temperature, volatile-rich vapor release during the late stages of fractional crystallization [198].

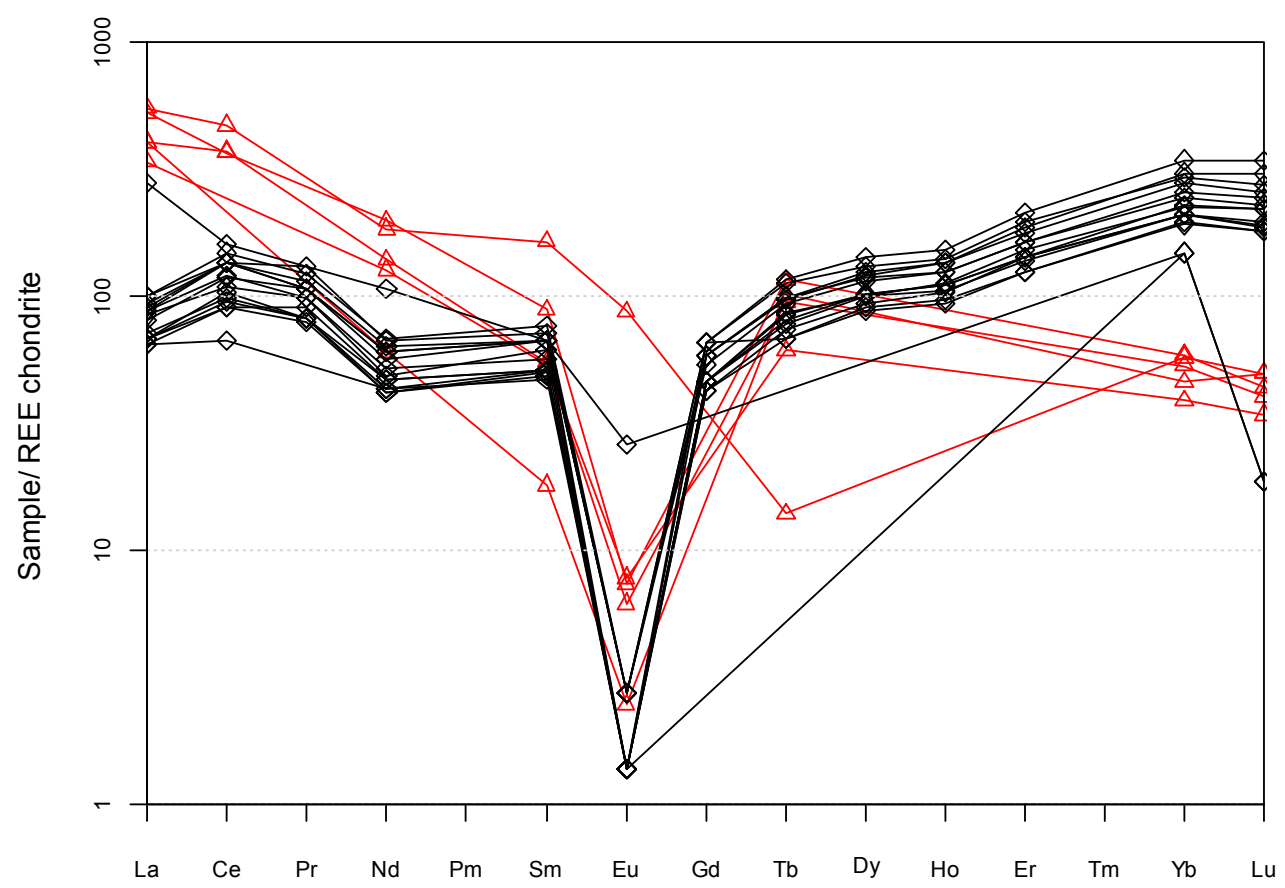

Figure 21. Chondrite-normalized [192] REE plots of the Sierra Blanca (black diamonds) and Aguachile (red triangles) rhyolites ([179,189], supplemental material).

\subsection{Aguachile, Coahuila, Mexico}

The Aguachile Be-F-U deposit in Coahuila, east of Big Bend National Park, Texas, is one of the eastern-most of the fluorite deposits in Mexico [42,49,187-189] and is part of the Trans-Pecos alkaline magmatic province (Figures 1 and 20). The Aguachile Mountain pluton was emplaced at or during the beginning of Rio Grande rift extension ( $(33-36 \mathrm{Ma})$. Aguachile Mountain is a collapse caldera and is surrounded by rhyolite domes with a plug of microsyenite that intruded Cretaceous limestones. Rhyolite and basanite ring dikes surround the dome and plug. Be-U-F veins, breccias, and replacements are found in limestone adjacent to the rhyolite dikes and contain fluorite, calcite, quartz, hematite, limonite, and minor amounts of aragonite, powellite, adularia, kaolinite, gypsum, sericite, and bertrandite [186,188]. The major ore body at Aguachile contains $0.1-0.3 \%$ BeO and beryllium is found only in the immediate Aguachile area, however the presence of peralkaline intrusion-related REE deposits is possible. Three periods of fluoritization are recognized [188]. Chemically the rhyolite is alkaline, peralkaline to slightly peraluminous and similar to topaz-bearing rhyolites. Chondrite-enriched REE patterns exhibit enriched light REE patterns with a negative Eu anomaly (Figure 21). The ore fluids had a $\mathrm{pH}$ of 3-5, Eh of +0.2 to -0.1 , and a temperature of above $150{ }^{\circ} \mathrm{C}[189]$. 


\subsection{Villa Ahumada Carbonatites, Mexico}

Carbonatites have been found in three areas a few kilometers west of Villa Ahumada in southern Chihuahua, Mexico (Figure 20) [47]. The Yucca, Mariana, and El Indio carbonatites occur as stocks, breccias, and dikes that intrude limestones, granitic intrusions, and rhyolite tuffs. Calcite, Fe-calcite, and hematite are the major minerals found in the carbonatites with minor dolomite, garnet, and other accessory minerals. These carbonatites are mostly classified as calciocarbonatite (sövite) and ferrocarbonatite (Figure 5; according to the classification by 193); magnesio-carbonatites are less abundant. Chondrite-enriched REE patterns exhibit enriched light REE and negative Eu anomaly (Figure 22). Associated igneous rocks include a porphyritic latite dated as $37.00 \pm 0.19$ Ma and Crest Tuff dated as $35.61 \pm 0.54 \mathrm{Ma}$. The carbonatite yielded an age of $36.35+0.27 \mathrm{Ma}$ [47]. Detailed mapping and ultimately drilling is required to properly assess the economic potential. The area is currently being examined for REE.

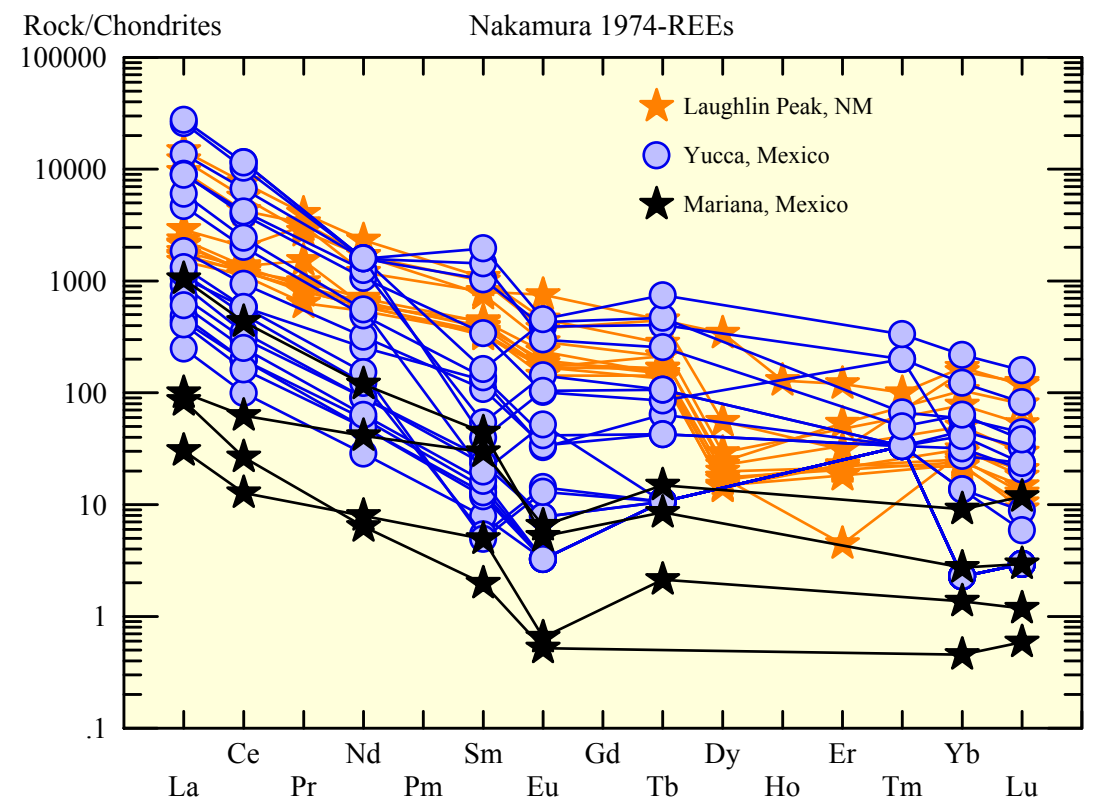

Figure 22. Chondrite-normalized [192] REE plot of carbonatites from Laughlin Peak, New Mexico and Villa Ahumada, Mexico ([47], supplemental material).

\section{Discussion and Conclusions}

\subsection{Age and Geochemistry of Associated Igneous Rocks}

The GPM mineral deposits in New Mexico, Trans-Pecos Texas, and eastern Mexico are associated with Eocene to Oligocene alkaline-igneous rocks and found in small- to medium-sized volcanic fields or porphyry systems, with ages ranging from 22 to $46 \mathrm{Ma}$ (Figure 23; Table 1). The GPM mineral deposits are younger than most alkaline-related REE and gold deposits elsewhere in the North American Cordilleran alkaline-igneous belt (Bear Lodge Mountains, 48-50 Ma [7]). Many of the igneous plutons associated with REE are zoned, whereas plutons and laccoliths associated with gold deposits are small to medium bodies that are not zoned. The igneous rocks in GPM districts are typically subalkaline to alkaline, predominantly metaluminous to peraluminous intrusions, with predominantly linear, light REE-enriched patterns with or without an europium anomaly (Table 1 and references therein). 


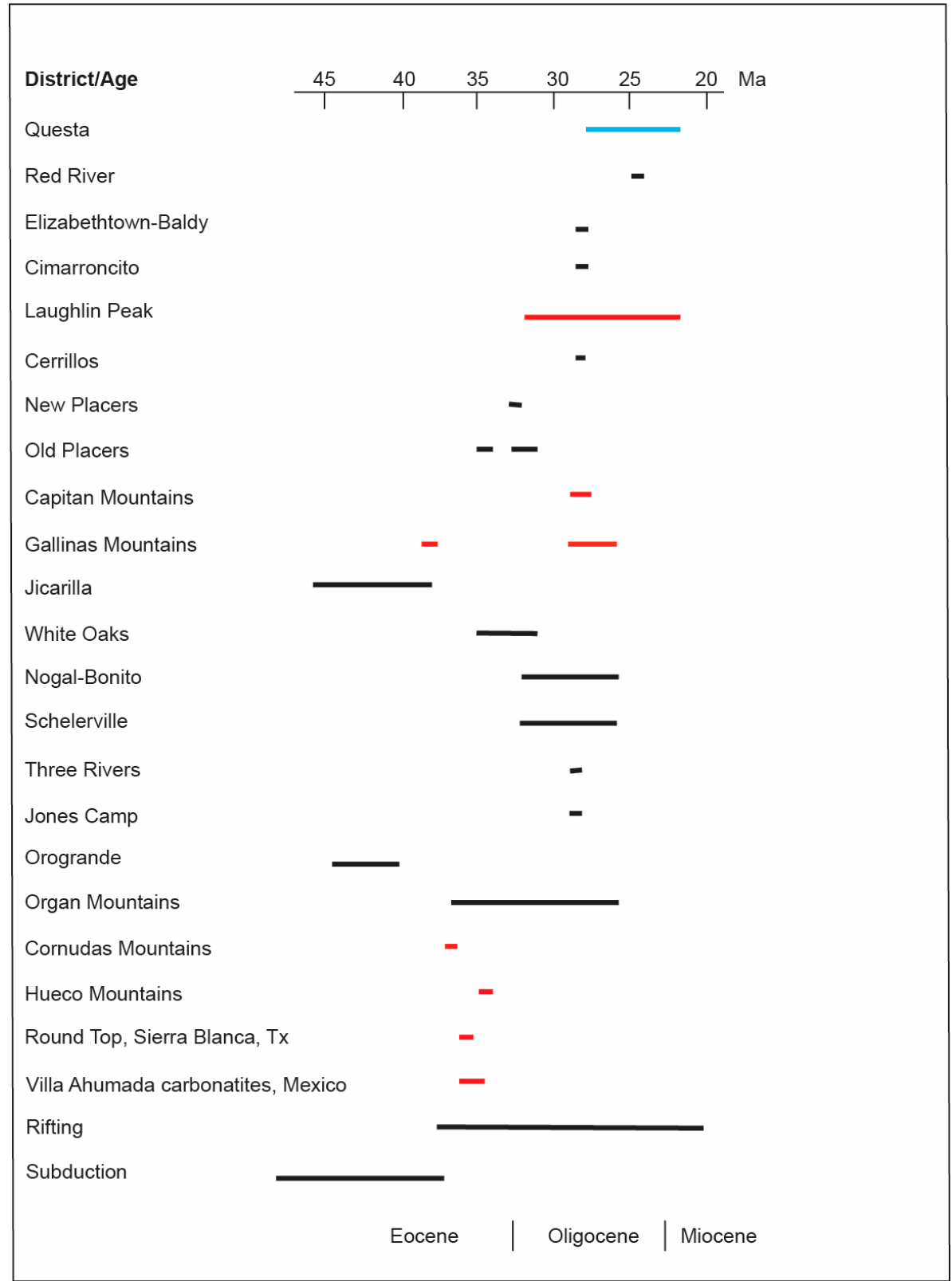

Figure 23. Ages of igneous rocks associated with GPM districts in New Mexico, Texas, and eastern Mexico, arranged from north to south. Ages and references are cited in Table 1. Districts are located in Figures 2 and 20. Blue line represents predominantly porphyry molybdenum district, red line represents predominantly REE districts, and the black lines represents predominantly gold districts. Rifting and subduction lines from [52,199]. Basin and range extension is approximately the same age as the rifting. There is a porphyry molybdenum deposit found in the Nogal-Bonito district, but the age is uncertain.

Igneous rocks in three of the GPM districts associated with predominantly REE deposits (Laughlin Peak, Gallinas Mountains, and Cornudas Mountains) are ferroan, alkali-calcic to alkali. Igneous rocks associated with the predominantly gold and molybdenum GPM districts are predominantly ferroan to magnesian, calc-alkalic to alkali-calcic to alkalic. The oldest igneous rocks in gold-rich Jicarilla Mountains and Orogrande district are mostly magnesian (with some ferroan in the Jicarilla Mountains), alkali-calcic to alkalic. Geochemically, the GPM rocks plot as WPG (within-plate granites) to VAG (volcanic arc granites) according to Pearce et al. [57], and active continental margins, according to 
Schandl and Gordon [60]. In contrast, igneous rocks associated with the Colorado Mineral Belt are magnesian, alkali-calcic to calc-alkalic and metaluminous to peraluminous [200].

$\mathrm{Sr}$ and $\mathrm{Nd}$ isotopes of igneous rocks associated with GPM districts are similar, and imply a lower to upper mantle, homogeneous source (Table 4). There are no correlations with age or spatial relationships. Nd isotopes of GPM deposits (epsilon $\mathrm{Nd}$ of -0.3 to -5.5 , Table 4 ) are higher than those of igneous intrusions associated with the Colorado Mineral Belt, where a crustal source is envisioned (epsilon Nd of -7 to -9 ) [200,201].

Table 4. Compilation of Sr and Nd isotopes of some GPM deposits. See Table 1 for reference of the age of the igneous systems. See Figure 2 for locations of areas. These isotopes are similar and imply a similar, lower to upper mantle, homogeneous source.

\begin{tabular}{cccccc}
\hline District ID & Name & Age & Sr Isotopes & Nd (CHUR ) & Isotope Reference \\
\hline DIS237 & Questa & $22-28$ & $0.7076-0.7069$ & & {$[64]$} \\
DIS020 & Laughlin Peak & $22.8-32.3$ & $0.7044,0.7039-0.7060$ & & {$[202]$} \\
DIS019 & Elizabethtown-Baldy & 29.1 & 0.70617 & {$[77]$} \\
DIS092 & Gallinas Mountains & $26.5-29.74$ & 0.7061 & -2.8 & {$[125]$} \\
DIS095 & Nogal-Bonito & $26-33$ & 0.7067 & -0.3 & {$[125]$} \\
DIS091 & Capitan Mountains & 28.3 & 0.70801 & -5 & {$[125]$} \\
DIS216 & Jones Camp & 28.88 & 0.70715 & -5.5 & {$[125]$} \\
DIS098 & Tecolote Iron & & $0.70490-0.70513$ & & {$[125]$} \\
DIS030 & Organ Mountains & $26-36$ & 0.7085 to 0.7060 & -5 & {$[156]$} \\
DIS099 & White Oaks & $31.7-34.7$ & 0.70673 & -3.7 & {$[125]$} \\
DIS128 & Cornudas Mountains & 36.3 & 0.7041 & & {$[165]$} \\
DIS093 & Jicarilla & $39.1-45.6$ & $0.70565-0.70578$ & -4.8 & {$[125]$} \\
\hline \multicolumn{5}{c}{}
\end{tabular}

The similar compositions of GPM igneous rocks (Tables 1 and 4) suggest that the magmas had a similar origin and were produced from similar source regions. Subtle differences are probably related to differences in fractional crystallization, especially of minerals such as garnet, zircon, and apatite, and water-rock interactions accounts for variations in $\mathrm{K}_{2} \mathrm{O}, \mathrm{Na}_{2} \mathrm{O}, \mathrm{Ba}, \mathrm{Rb}$, and Sr. Alternatively, these differences could represent differences in crustal host rocks, especially in areas where crustal xenoliths are common (such as in the Organ pluton [156] and Jicarilla igneous intrusions). Collectively, the geochemical and isotopic data (Tables 1 and 4) are consistent with the older rocks (Jicarilla Mountains, Orogrande) and Cornudas Mountains having an asthenospheric source and the younger rocks having a source in the lower crust with more contamination from the upper crust.

The youngest ages of igneous rocks associated with GPM deposits (22-24 Ma) are in northern New Mexico (Questa, Red River, and Laughlin Peak districts). Only three districts have associated igneous rocks older than $36 \mathrm{Ma}$ (Old Placers, Jicarilla, and Orogrande districts) and they are in central and southern New Mexico. Note that intrusions in the Tecolote and Duran districts remain undated.

Detailed ${ }^{40} \mathrm{Ar} /{ }^{39} \mathrm{Ar}$ studies in several districts suggest tighter constraints in timing of magmatic activity, emphasizing the need for additional detailed ${ }^{40} \mathrm{Ar} /{ }^{39} \mathrm{Ar}$ and $\mathrm{U} / \mathrm{Pb}$ geochronological studies. In the Ortiz porphyry belt, detailed ${ }^{40} \mathrm{Ar} /{ }^{39} \mathrm{Ar}$ studies indicate an early calc-alkaline (34.29-35.79 Ma) phase and younger, slightly alkaline (31.68-33.27 Ma) phase [87]. Cross cutting relations at Carache Canyon in the Ortiz porphyry belt suggest that the 31.56-32.20 Ma ${ }^{40} \mathrm{Ar} /{ }^{39} \mathrm{Ar}$ range of ages of adularia is the age of mineralization [87]. The total duration of volcanic and intrusive activity at the Questa caldera was 9.2 m.y., beginning at 28.5 and ending at $19.3 \mathrm{Ma}$ [71]. The Organ caldera complex was emplaced between 36.45 and $36.03 \mathrm{Ma}$, followed by intrusion of exposed post-caldera plutons between 36.1 and 35.7 Ma. Reheating events suggest additional unexposed, post-caldera plutons in the Organ Mountains at $34 \mathrm{Ma}, 32-30 \mathrm{Ma}$, and $26 \mathrm{Ma}$, for a total duration of magmatic activity of $10.45 \mathrm{~m} . \mathrm{y}$. [157]. Other areas, especially those associated with REE deposits, are shorter periods of magmatic activity (such as the Capitan and Cornudas Mountains). Mineralization appears to be related to magmatic activity as evidenced by field relationships, isotopic data, and fluid inclusion data. The enrichment of beryllium and REE in the Round Top laccolith, Texas was the result of removal of compatible elements 
from the magma chamber by emplacement of earlier igneous intrusions [186], suggesting that the longer duration of magmatic activity enhances the possibility of forming larger REE deposits.

\subsection{Geology, Geochemistry and Style of Mineralization of GPM Districts}

Detailed geologic mapping of several districts in the GPM portion of the North American Cordilleran alkaline-igneous belt have documented evidence of local structural control of intrusive rocks and mineral deposits $[78-80,87,108,122,170]$. REE deposits are typically found along local faults (Figures 3, 7 and 9). Regional structures such as the Capitan lineament appear to be important [43]. Generally, gold-bearing magmatic-hydrothermal breccia pipes and porphyry deposits are older than Th-REE-fluorite $( \pm \mathrm{U}, \mathrm{Nb})$ epithermal veins and breccias and Fe skarns $[90,108]$. General paragenesis includes early base-metal veins or skarns followed by gold veins and subsequently Th-REE-fluorite $( \pm \mathrm{U}, \mathrm{Nb})$ epithermal veins and breccias $[90,108,136,137]$.

Gold/silver ratios in GPM deposits are generally higher than other deposits in New Mexico and also have high gold/base-metal ratios, unlike other metal deposits in the state $[2,23,24,29,30]$. Geochemical analyses of many samples from GPM districts exhibit low silver, copper, lead, and zinc concentrations (relative to other metal deposits in western New Mexico [29-32]); only deposits in the Cerrillos, Organ and Gallinas Mountains have significant silver, copper, lead, and zinc production [23,24]. Deposits of REE also are found in several GPM districts in New Mexico, Texas, and eastern Mexico (Figure 2, Table 1, Laughlin Peak and Gallinas, Capitan, and Cornudas Mountains, Sierra Blanca, Mexican carbonatites), but are typically not found with significant gold deposits, although trace amounts of gold are locally present $[24,82,102,104,108,119,168]$. The most significant REE deposits in terms of future potential are found throughout the GPM belt and show no common location, age or composition characteristics.

In New Mexico, the style of mineralization differs from that found in Colorado. Fluorine and gold are common in both areas. Tellurium is found in most of the Colorado districts, but most GPM districts in New Mexico have tungsten and iron skarns, with only trace amounts to no tellurium [4,26,31,32]. Carbonatites are only found in New Mexico and Mexico. Iron skarns with local concentrations of gold and REE are found in many GPM districts in New Mexico (Table 1 [62]) and most are associated with elevated REE and gold. However, in Texas and eastern Mexico, tellurium, tungsten and iron skarns are absent. However, tellurium analyses of samples from the GPM districts are limited and tellurium could be found in specific mineralizing zones within New Mexico, Texas, and eastern Mexico districts. More detail mapping and mineral and chemical analyses are required.

\subsection{Origin of GPM Deposits}

These new studies have not resolved the origin of the alkaline-igneous complexes nor the associated mineral deposits, but have provided a better understanding of their origin and provide insights beneficial for exploration. Supporting evidence for a magmatic-hydrothermal origin of GPM mineral deposits include the following: (1) fluid inclusion data, age determinations, and stable isotopic evidence from the Capitan quartz veins [122,126-128] and Nogal-Bonito deposits [136-138,140], (2) nature of stockwork molybdenum deposits at Sierra Blanca [131], (3) close spatial association of the nine types of deposits with igneous rocks $[44,108,125]$, (4) presence of skarn deposits along the contacts of the igneous rocks [44,108], (5) similar age determinations between igneous intrusions and associated mineralization and alteration [23,24], (6) geochemistry, fluid inclusion and geochemical modeling studies in the Gallinas Mountains district [106-110] and (7) similarity of New Mexico deposits to other deposits at Cripple Creek, Colorado and elsewhere where a magmatic origin is favored [26,35,89,90,201]. GPM are found along a long, linear, cratonic boundary (Great Plains and Rocky Mountains) that has a geologic history spanning hundreds of million years [24,27]. The Rio Grande rift formed in close proximity and parallels this boundary. This cratonic boundary formed a pathway that allowed the generation of alkaline and more silicic magmas and hydrothermal fluids that led to the formation of the GPM deposits. The diversity of igneous rocks, including alkaline-igneous 
rocks, and associated mineral deposits along this boundary suggests that this region is characterized by highly fractionated and differentiated, multiple pulses of mantle-derived magmas evolving to lower crustal magmas related to the subduction of the Farallon plate. The differences in incompatible trace elements, including REE and beryllium, between the different granitic to rhyolite rocks are likely related to either differences in the crustal rocks that were assimilated during magmatic differentiation or by potential minor contamination from crustal sources and/or magma mixing.

The presence of carbonatites is important in understanding the origin of GPM deposits. The carbonatites at Laughlin Peak and in Mexico are best described as carbonatites associated with potassic and sodic plutonic rocks [203]. This type of carbonatites typically represents low-temperature, low-pressure, fractional-crystallization derivatives of diverse alkaline parental magmas derived from metasomatized lithospheric mantle [203-205]. Thus, both upper mantle and lower to upper crustal source rocks are involved in forming GPM deposits, which is supported by the geochemical and isotopic evidence (Tables 1 and 4).

Many REE deposits associated with igneous rocks are found in extensional settings where thinning of the crust allows for melting of upper mantle magmas [206]. Several studies have attributed changes in the chemistry and source of the magmas to the tectonic transition between Eocene-early Oligocene subduction (Laramide, 36-75 Ma) and mid-Tertiary extension (20-36 Ma) $[124,199,200]$ that was triggered by changes in the subducting Farallon plate. As the Farallon slab fragmented [166,207], the asthenosphere filled gaps between the sinking slab and overlying lithosphere, producing magmas and thereby accounting for slight differences between chemical compositions of the exposed igneous rocks within the GPM belt. The source regions shifted from asthenosphere (with some minor enrichment or metasomatism) with some contamination from the upper crust during Eocene-early Oligocene to lower crust during the late Oligocene [199]. The alkaline-igneous rocks within the GPM districts are likely derived from partial melting within the lithosphere mantle and lower crust, possibly reflecting metasomatism of the upper mantle $[2,3,24,208]$. Rollback of the Farallon flat slab occurred about 23-37 Ma and resulted in a tremendous pulse of calc-alkaline ignimbrite eruptions in southwestern New Mexico and central Mexico west of the GPM deposits [50,52,207].

Deep-seated fracture systems or crustal lineaments probably channeled the magmas and hydrothermal fluids [43]. Once magmas and metal-rich fluids reached shallow levels, local structures and wall rock compositions determined distribution of and final style of intrusions and resulting mineral deposits.

\section{Resources and Future Exploration Potential}

Although a few alkaline-related mineral deposits are large (like Cripple Creek gold deposit and Bear Lodge Mountains REE deposit) [209], most of the GPM deposits are quite small [24], although most in New Mexico, west Texas, and eastern Mexico have not been explored at depth. However, the repetitive occurrence of carbonatites with Th-REE-fluorite $( \pm \mathrm{U}, \mathrm{Nb})$ vein deposits suggests that similar REE-rich carbonatites are likely in the subsurface of some of these systems, which could be indicative of larger REE deposits [7]. The presence of iron skarns containing minor amounts of gold and REE could also be an indicator of additional REE deposits in the subsurface. The lack of abundant quartz in these systems results in these deposits being less resistant to erosion, being covered, and not as well exposed as other types of quartz-rich deposits [209], therefore requiring detailed mapping, geochemical and geophysical studies and ultimately drilling to properly define their extent.

Gold and molybdenum resources in New Mexico have been summarized before [24,31,32,62]. There is REE potential in Th-REE-fluorite $( \pm \mathrm{U}, \mathrm{Nb})$ epithermal veins and breccias in the Laughlin Peak, Gallinas Mountains, Capitan Mountains, Cornudas Mountains, Round Top, and Villa Ahumada districts $[8,19,47]$ and exploration, including drilling, has recently occurred in the Gallinas Mountains, Cornudas Mountains, Round Top, and Villa Ahumada areas. In 1991-1992, U.S. Bureau of Mines calculated an inferred resource of 0.487 million metric tons of total REE (grade of $2.95 \%$ total REE) in the Gallinas Mountains district [105]. The Round Top Mountain, Sierra Blanca, Texas, contains an 
estimated 231.0 Mt of rare-earth mineral resources at the Measured level, with an average grade of $0.06 \mathrm{wt} \%$ total rare-earth oxide (TREO), $298.0 \mathrm{Mt}$ of resources at the Indicated level, with an average grade of $0.06 \%$ TREO, and an estimated $377.0 \mathrm{Mt}$ of resources at the Inferred level, with an average grade of $0.06 \%$ TREO $[8,180,185]$. Since the model for peralkaline intrusion-related REE deposits (USGS model no. $11[8,39,41])$ is now better understood, those peralkaline-igneous rocks in GPM districts (Table 1) and those found in the Tran-Pecos belt $[165,166,179]$, many without any surface indications of mineral deposits, should be re-examined for REE, gold, and other critical elements deposits, requiring detailed mapping and geochemical studies in most areas. In addition, some of the GPM districts could have potential for other critical elements (as defined by [10]), such as fluorine, zirconium, scandium, niobium, gallium, beryllium and tellurium.

Supplementary Materials: The following are available online at http://www.mdpi.com/2079-9276/7/1/8/s1, Table S1. Chemical analyses of igneous and mineralized rocks. Major elements are in weight percent. Trace elements are in ppm, except for Au which is in ppb.

Acknowledgments: This report is part of on-going studies of mineral resources and the geology of carbonatites and alkaline-igneous rocks in New Mexico, supported and funded by the New Mexico Bureau of Geology and Mineral Resources, Nelia Dunbar, Director and State Geologist. I would like to thank many colleagues who contributed to and reviewed manuscripts over the years much of this work is based upon, especially Robert North, Felix Mutschler, Karen Kelley, Steve Ludington, and Miles Silverman. Many graduate studies provided boots-on-the-ground in many of these districts that I have summarized and their work is greatly appreciated. The New Mexico Geological Society funded portions of the graduate students work. Visits to the Mexican deposits were made possible in 1997 by Steve Ludington of the USGS and members of the Consejo de Recursos Minerales (funded by the USGS). Matt Heizler, Lisa Peters and Rich Esser carried out the mineral separations and ${ }^{40} \mathrm{Ar} /{ }^{39} \mathrm{Ar}$ age determinations at the New Mexico Geochronology Laboratory at the New Mexico Bureau of Geology and Mineral Resources over the years and their help in understanding the temporal relationships of the mineral deposits is appreciated. Special thanks to two anonymous reviewers who provided thoughtful comments. Finally, I thank my husband, James McLemore, for his assistance in the field and patience while working on these projects.

Author Contributions: The author contributed the literature search, field mapping, chemical data, mineralogical data and interpretation and writing of the text.

Conflicts of Interest: The author declares no conflict of interest.

\section{References}

1. $\quad$ Lindgren, W. Mineral Deposits, 4th ed.; McGraw-Hill: New York, NY, USA, 1913; 930p.

2. Mutschler, F.E.; Griffin, M.E.; Stevens, D.S.; Shannon, S.S., Jr. Precious metal deposits related to alkaline rocks in the North American Cordillera-An interpretive review. Trans. Geol. Soc. Am. 1985, 88, 355-377.

3. Mutschler, F.E.; Mooney, T.C.; Johnson, D.C. Precious metal deposits related to alkaline igneous rocks-a space-time trip through the Cordillera. Miner. Eng. 1991, 43, 304-309.

4. McLemore, V.T. Tellurium Deposits in New Mexico: SME Annual Meeting Preprint 13-104. Littleton, CO, USA, 2013. Available online: http://geoinfo.nmt.edu/staff/mclemore/projects/mineralresources/ documents /13-104.pdf (accessed on 20 January 2018).

5. Kelley, K.D.; Sry, P.G. Critical Elements in Alkaline Igneous Rock-Related Epithermal Gold Deposits: Chapter 9 InRare Earth and Critical Elements in Ore Deposits; Reviews in Economic Geology 18; Verplanck, P.L., Hitzman, M.W., Eds.; Society of Economic Geologists: Littleton, CO, USA, 2016; pp. 195-216.

6. Maehl, W.C. Zortman and Landusky with 20/20 Hindsight. 2000. Available online: https://fs.ogm.utah. gov/pub/MINES/AMR_Related/NAAMLP/EnDesign/Maehl.pdf (accessed on 20 January 2018).

7. Millonig, L.J; Groat, L.A. Carbonatites in western North America-Occurrences and metallogeny. In Tectonics, Metallogeny, and Discovery: The North American Cordillera and Similar Accretionary Settings; Special Publication 17; Colpron, M., Bissig, T., Rusk, B.G., Thompson, J.F.H., Eds.; Society of Economic Geologists: Littleton, CO, USA, 2013; pp. 245-264.

8. Van Gosen, B.S.; Verplanck, P.L.; Seal, R.R., II; Long, K.R.; Gambogi, J. Rare-earth elements, chap. O. In Critical Mineral Resources of the United States-Economic and Environmental Geology and Prospects for Future Supply; U.S. Geological Survey Professional Paper 1802; Schulz, K.J., DeYoung, J.H., Jr., Seal, R.R., II, Bradley, D.C., Eds.; United States Geological Survey: Reston, VA, USA, 2017; pp. O1-O31. 
9. Du, X.; Graedel, T.E. Global in-use stocks of the rare earth elements: A first estimate. Environ. Sci. Technol. 2011, 45, 4096-4101. [CrossRef] [PubMed]

10. Schulz, K.J.; De Young, J.H., Jr.; Bradley, D.C.; Seal, R.R., II. Critical mineral resources of the United States-An introduction, chap. A. In Critical Mineral Resources of the United States-Economic and Environmental Geology and Prospects for Future Supply; Professional Paper 1802; Schulz, K.J., DeYoung, J.H., Jr., Seal, R.R., II, Bradley, D.C., Eds.; U.S. Geological Survey: Reston, VA, USA, 2017; pp. A1-A14.

11. Naumov, A.V. Review of the world market of rare-earth metals. Russ. J. Non-Ferrous Met. 2008, 49, 14-22.

12. Committee on Critical Mineral Impacts of the U.S. Economy. Minerals, Critical Minerals, and the U.S. Economy: Committee on Earth Resources; National Research Council: Washington, DC, USA, 2008; 264p, ISBN 0-309-11283-4.

13. Hedrick, J.B. Rare Earths (Advanced Release): 2007 Minerals Yearbook; U.S. Geological Survey: Reston, VA, USA, 2009; 20p. Available online: http:/ / www.usmagneticmaterials.com/documents/USGS-RE-MineralsYearbook.pdf (accessed on 22 January 2018).

14. Haxel, G.B.; Hedrick, J.B.; Orris, G.J. Rare Earth Elements_Critical Resources for High Technology; Fact Sheet; U.S. Geological Survey: Reston, VA, USA, 2002.

15. Guyonnet, D.; Planchon, M.; Rollat, A.; Escalon, V.; Tuduri, J.; Charles, N.; Vaxelaire, S.; Didier, D.; Fargier, H. Material flow analysis applied to rare earth elements in Europe. J. Clean. Prod. 2015, 107, 215-228. [CrossRef]

16. Chakhmouradian, A.R.; Wall, F. Rare earth elements: Minerals, mines, magnets (and more). Elements 2012, 8 , 333-340. [CrossRef]

17. McLemore, V.T.; North, R.M.; Leppert, S. Rare-earth elements (REE), niobium and thorium districts and occurrences in New Mexico. In New Mexico Bureau of Mines and Mineral Resources; Open-file Report OF-324; AGI: Harrisburg, PA, USA, 1988; 28p.

18. McLemore, V.T.; North, R.M.; Leppert, S. Rare-earth elements (REE) in New Mexico. N. M. Geol. 1988, 10, 33-38.

19. Long, K.R.; van Gosen, B.S.; Foley, N.K.; Cordier, D. The Principle Rare Earth Elements Deposits of the United States-A Summary of Domestic Deposits and a Global Perspective; Scientific Investigations Report 2010-5220; U.S. Geological Survey: Reston, VA, USA, 2010.

20. Bonham, H.F., Jr. Models for volcanic-hosted epithermal precious metal deposits. In Bulk Mineable Precious Metal Deposits of the Western United States; Geological Society of Nevada: Reno, NV, USA, 1988; pp. 259-271.

21. Thompson, T.B. Genesis of gold associated with alkaline igneous rocks (abstr.). Geol. Soc. Am. Abstr. Programs 1991, 23, 99-100.

22. Richards, J.P. Magmas, fluids, and ore deposits. In Alkalic-Type Epithermal Gold Deposits—A Review; Short Course Series; Thompson, J.F.H., Ed.; Mineralogical Association of Canada: Québec City, QC, Canada, 1995; Volume 23, pp. 367-400.

23. McLemore, V.T. Great Plains Margin (alkalic-related) gold deposits in New Mexico. In Geology and Ore Deposits of the American Cordillera; Cyner, A.R., Fahey, P.L., Eds.; Geological Society of Nevada: Reno/Sparks, NV, USA, 1996; pp. 935-950.

24. McLemore, V.T. Great Plains Margin (alkaline-related) gold deposits in New Mexico: Twenty years later. In New Concepts and Discoveries, 2015 Symposium Volume; Geological Society of Nevada: Reno/Sparks, NV, USA, 2015; Volume II, pp. 1305-1328.

25. Jensen, E.P.; Barton, M.D. Gold Deposits Related to Alkaline Magmatism; Society of Economic Geologists: Littleton, CO, USA, 2000; Volume 13, pp. 279-314.

26. Kelley, K.D.; Luddington, S. Cripple creek and other alkaline-related gold deposits in the southern Rocky Mountains, USA: Influence of regional tectonics. Miner. Depos. 2002, 37, 38-60. [CrossRef]

27. Chapin, C.E.; Kelley, S.A.; Cather, S.M. The Rocky Mountain front, southwestern USA. Geosphere 2014, 10, 1043-1060. [CrossRef]

28. Potter, L.S. Chemical variation along strike in feldspathoidal rocks of the eastern alkali belt, Trans-Pecos magmatic province, Texas and New Mexico. Can. Miner. 1996, 34, 241-264.

29. North, R.M.; McLemore, V.T. Silver and Gold Occurrences in New Mexico; Resource Map 15; Scale 1:1,000,000; New Mexico Bureau of Mines and Mineral Resources: Socorro, NM, USA, 1986; 32p. 
30. North, R.M.; McLemore, V.T. A Classification of the Precious Metal Deposits of New Mexico. In Bulk Mineable Precious Metal Deposits of the Western United States Symposium Volume, Proceedings of the Geological Society of Nevada, Reno, Nevada, 6-8 April 1987; Geological Society of Nevada: Reno/Sparks, NV, USA, 1988; pp. 625-660.

31. McLemore, V.T. Silver and Gold Resources in New Mexico; Resource Map 21; New Mexico Bureau of Mines and Mineral Resources: Socorro, NM, USA, 2001; 60p.

32. McLemore, V.T.; Lueth, V. Metallic Mineral Deposits. In Energy and Mineral Deposits in New Mexico; McLemore, V.T., Timmons, S., Wilks, M., Eds.; New Mexico Bureau of Geology and Mineral Resources Memoir 50 and New Mexico Geological Society Special Publication: Socorro, NM, USA, 2017; Volume 13, 79p.

33. Cox, D.P.; Bagby, W.C. Descriptive models of Au-Ag-Te veins. In Mineral Deposit Models: U.S. Geological Survey, Bulletin 1693; Cox, D.P., Singer, D.A., Eds.; U.S. Geological Survey: Reston, VA, USA, 1986; p. 124.

34. Bliss, J.D.; Sutphin, D.M.; Moiser, D.L.; Allen, M.S. Grade-tonnage and Target-area Models of Au-Ag-Te Veins Associated with Alkalic Rocks; OF 92-208; U.S. Geological Survey: Reston, VA, USA, 1992; 15p.

35. Kelley, K.D.; Romberger, S.B.; Beaty, D.W.; Pontius, J.A.; Snee, L.W.; Stein, H.J.; Thompson, T.B. Geochemical and geochronological constraints on the genesis of Au-Te deposits at Cripple Creek, Colorado. Econ. Geol. 1998, 93, 981-1012. [CrossRef]

36. Fulp, M.S.; Woodward, L.A. Mineral deposits of the New Mexico alkalic province (abstr.). Geol. Soc. Am. Abstr. Programs 1991, 23, 23.

37. Fulp, M.S.; Woodward, L.A. The Mudpuppy-Waterdog Prospect, an Alkalic Copper-Gold Porphyry System in the NOGAL-Bonito Mining District; Guidebook 42; New Mexico Geological Society: Socorro, NM, USA, 1991; pp. 327-328.

38. Thompson, T.B. The Bonito-Nogal district, Lincoln County, New Mexico (abstr.). Geol. Soc. Am. Bull. Abstr. Programs 1991, 23, 99.

39. Cox, D.P.; Singer, D.A. (Eds.) Mineral Deposit Models; Bulletin 1693; U.S. Geological Survey: Reston, VA, USA, $1986 ; 379 \mathrm{p}$.

40. Rytuba, J.J.; Cox, D.P. Porphyry Gold: A Supplement to U.S. Geological Survey Bulletin 1693; Open-File Report 91-116; U.S. Geological Survey: Reston, VA, USA, 1991; 7p. Available online: http:/ /pubs.usgs.gov/of/ 1991/0116/report.pdf (accessed on 20 January 2018).

41. Verplanck, P.L.; Van Gosen, B.S.; Seal, R.R.; McCafferty, A.E. A Deposit Model for Carbonatite and Peralkaline Intrusion-Related Rare Earth Element Deposits: Chapter J in Mineral Deposit Models for Resource Assessment; Scientific Investigations Report 2010-5070-J; U.S. Geological Survey: Reston, VA, USA, 2014; 58p.

42. Foley, N.K.; Hofstra, A.H.; Lindsey, D.A.; Seal, R.R., II; Jaskula, B.; Piatak, N.M. Occurrence model for volcanogenic beryllium deposits, chap. F. In Mineral Deposit Models for Resource Assessment; Scientific Investigations Report 2010-5070-F; U.S. Geological Survey: Reston, VA, USA, 2012; 43p.

43. McLemore, V.T.; Zimmerer, M. Magmatic Activity and Mineralization along the Capitan; In Santa Rita, and Morenci Lineaments in the Chupadera Mesa Area, Central New Mexico. Guidebook 60; New Mexico Geological Society: Socorro, NM, USA, 2009; pp. 375-386.

44. McLemore, V.T. Geology and Mineral Resources of the Laughlin Peak Mining District; Guidebook 66; New Mexico Geological Society: Socorro, NM, USA, 2015; pp. 277-288.

45. McLemore, V.T.; Dunbar, N.; Heizler, L.; Heizler, M. Geology and Mineral Deposits of the Orogrande Mining District; Guidebook 65; New Mexico Geological Society: Socorro, NM, USA, 2014; pp. 247-259.

46. McLemore, V.T.; Phillips, R.S. Geology of Mineralization and Associated Alteration in the Capitan Mountains; Guidebook 42; New Mexico Geological Society: Socorro, NM, USA, 1991; pp. 291-298.

47. Nandigam, R. Geology and Geochemistry of Newly Discovered Tertiary Carbonatite Occurrences near Villa Ahumada Area, Basin and Range Province, Chihuahua, Northern Mexico. Ph.D. Thesis, University of Texas at El Paso, El Paso, TX, USA, 2000.

48. McLemore, V.T. Rare Earth Elements Deposits in New Mexico. In Arizona Geological Survey Special Paper \#9; Chapter 3, Proceedings of the 48th Annual Forum on the Geology of Industrial Minerals, Phoenix, Arizona, 30 April-4 May 2012; Conway, F.M., Ed.; 2014; pp. 1-16. Available online: http:/ / repository.azgs.az.gov/uri_ gin/azgs/dlio/1568 (accessed on 20 January 2018).

49. Woolley, A.R. Alkaline Rocks and Carbonatites of the World, Part 1: North and South America; University of Texas Press: Austin, TX, USA, 1987. 
50. Chapin, C.E.; Jahns, R.H.; Chamberlin, R.M.; Osburn, G.R. First day road log from Socorro to Truth or Consequences via Magdalena and Winston. In Field Guild to Selected Caldrons and Mining Districts of the Datil-Mogollon Volcanic Field, New Mexico; Special Publication No. 7; New Mexico Geological Society: Socorro, NM, USA, 1978; pp. 17-19.

51. Sims, P.K.; Stein, H.J.; Finn, C.A. New Mexico structural zone-An analogue of the Colorado mineral belt. Ore Geol. Rev. 2002, 21, 211-225. [CrossRef]

52. Chapin, C.E.; Wilks, M.; McIntosh, W.C. Space-Time Patterns of Late Cretaceous to Present Magmatism in New Mexico; Comparison with Andean Volcanism and Potential for Future Volcanism; InTectonics, Geochronology and Volcanism in the Southern Rocky Mountains and Rio Grande rift: New Mexico Bureau of Geology and Mineral Resources; Bulletin 160; Socorro, NM, USA, 2004; pp. 13-40. Available online: http:/ /geoinfo.nmt. edu/publications/monographs/bulletins/160/downloads/02chapin.pdf (accessed on 20 January 2018).

53. McLemore, V.T.; Hoffman, G.; Smith, M.; Mansell, M.; Wilks, M. Mining Districts of New Mexico; Open-file Report [CD-ROM]; New Mexico Bureau of Mines and Mineral Resources: Socorro, NM, USA, 2005.

54. McLemore, V.T.; Krueger, C.B.; Johnson, P.; Raugust, J.S.; Jones, G.E.; Hoffman, G.K.; Wilks, M. New Mexico Mines Database. Miner. Eng. 2005, 27, 42-49.

55. File, L.; Northrop, S.A. County, Township, and Range Locations of New Mexico's Mining Districts; Circular 84; New Mexico Bureau of Mines and Mineral Resources: Socorro, NM, USA, 1966; 66p.

56. Irvine, T.N.; Baragar, W.R.A. A guide to the chemical classification of the common volcanic rocks. Can. J. Earth Sci. 1971, 8, 523-548. [CrossRef]

57. Pearce, J.A.; Harris, N.B.W.; Tindle, A.G. Trace element discrimination diagrams for the tectonic interpretation of granitic rocks. J. Petrol. 1984, 24, 956-983. [CrossRef]

58. Frost, B.D.; Barnes, C.G.; Collins, W.J.; Arculus, R.J.; Ellis, D.J.; Frost, C.D. A geochemical classification for granitic rocks. J. Petrol. 2001, 42, 2033-2048. [CrossRef]

59. Frost, B.D.; Frost, C.D. A geochemical classification for feldspathic igneous rocks. J. Petrol. 2008, 49, 1955-1969. [CrossRef]

60. Schandl, E.S.; Gorton, M.P. Application of high field strength elements to discriminate tectonic settings in VMS environments. Econ. Geol. 2002, 97, 629-642. [CrossRef]

61. Whalen, J.B.; Currie, K.L.; Chappell, B.W. A-Type granites: Geochemical characteristics, discrimination and petrogenesis. Contrib. Miner. Petrol. 1987, 95, 407-419. [CrossRef]

62. McLemore, V.T. Mining Districts and Prospect Areas of New Mexico; Resource Map 24; Scale 1:1,000,000; New Mexico Bureau of Geology and Mineral Resources: Socorro, NM, USA, 2017; 65p.

63. Lipman, P.W. Incremental assembly and prolonged consolidation of Cordilleran magma chambers: Evidence from the Southern Rocky Mountain volcanic field. Geosphere 2007, 3, 42-70. [CrossRef]

64. Laughlin, A.W.; Rehrig, W.A.; Mauger, R.L. K-Ar chronology and sulfur and strontium isotope ratios at the Questa mine, New Mexico. Econ. Geol. 1969, 64, 903-909. [CrossRef]

65. Dillet, B.; Czamanske, G.K. Aspects of the Petrology, Mineralogy, and Geochemistry of the Granitic Rocks Associated with Questa Caldera, Northern New Mexico; Open-File Report 87-0258; U.S. Geological Survey: Reston, VA, USA, 1987; 238p.

66. Johnson, C.M.; Czamanske, G.K.; Lipman, P.W. Geochemistry of intrusive rocks associated with the Latir volcanic field, New Mexico, and contrasts between evolution of plutonic and volcanic rocks. J. Contrib. Miner. Petrol. 1989, 103, 90-109. [CrossRef]

67. Czamanske, G.K.; Allen, J.C. The ${ }^{40} A r{ }^{39}$ Ar Chronology of Caldera Formation, Intrusive Activity and Mo-Ore Deposition Near Questa, New Mexico; InTectonic Development of the Southern Sangre de Cristo Mountains, New Mexico; Guidebook 41; Bauer, P.W., Lucas, S.G., Mawer, C.K., McIntosh, W.C., Eds.; New Mexico Geological Society: Socorro, NM, USA, 1990; pp. 355-358.

68. Ross, P.S.; Jebrak, M.; Walker, B.M. Discharge of hydrothermal fluids from a magma chamber and concomitant formation of a stratified breccia zone at the Questa porphyry molybdenum deposit, New Mexico. Econ. Geol. 2002, 97, 1679-1699. [CrossRef]

69. McLemore, V.T. Geologic Setting and Mining History of the Questa Mine; Open-file report 515; New Mexico Bureau of Geology and Mineral Resources: Socorro, NM, USA, 2009; 29p.

70. Rowe, A. Ore Genesis and Fluid Evolution of the Goat Hill Orebody, Questa Climax-Type Porphyry-Mo System, New Mexico and Its Comparison to the Climax-Type Deposits of the Colorado Mineral Belt. Ph.D. Thesis, New Mexico Institute Mining Technology, Socorro, NM, USA, 2012. 
71. Zimmerer, M.J.; McIntosh, W.C. The geochronology of volcanic and plutonic rocks at the Questa caldera: Constraints on the origin of caldera-related silicic magmas. Geol. Soc. Am. 2012, 124, 1394-1408. [CrossRef]

72. Roberts, T.T.; Parkison, G.A.; McLemore, V.T. Geology of the Red River District, Taos County, New Mexico; Guidebook 41; New Mexico Geological Society: Socorro, NM, USA, 1990; pp. 375-380.

73. Lindgren, W.; Graton, L.C.; Gordon, C.H. The Ore Deposits of New Mexico; Professional Paper 68; U.S. Geological Survey: Reston, VA, USA, 1910; 361p.

74. Lee, W.T. The Aztec Gold Mine, Baldy, New Mexico; Bulletin 620; U.S. Geological Survey: Reston, VA, USA, 1916; pp. 325-330.

75. Pettit, R.F. Mineral Resources of Colfax County, New Mexico; Open-file Report 15; New Mexico Bureau of Mines and Mineral Resources: Socorro, NM, USA, 1946; 73p.

76. Pearson, J.B. A New Mexico Gold Story-The Elizabethtown-Red River area. Ph.D. Thesis, University Texas, Austin, TX, USA, 1955; pp. 1-534.

77. Kish, S.A.; Ragland, P.C.; Cannon, R.P. Petrochemistry of the Palisades Sheet, Cimarron Pluton, Northern New Mexico; Guidebook 41; New Mexico Geological Society: Socorro, NM, USA, 1990; pp. 341-347.

78. Staatz, M.H. Geology and Description of the Thorium and Rare-Earth Veins in the Laughlin Peak Area, Colfax County, New Mexico; Professional Paper 1049-E; U.S. Geological Survey: Reston, VA, USA, 1985; 32p.

79. Staatz, M.H. Geologic Map of the Pine Buttes Quadrangle, Colfax County, New Mexico; Quadrangle Map GQ-1591; Scale 1:24,000; U.S. Geological Survey: Reston, VA, USA, 1986.

80. Staatz, M.H. Geologic Map of the Tres Hermanos Peak Quadrangle, Colfax County, New Mexico; Quadrangle Map GQ-1605; Scale 1:24,000; U.S. Geological Survey: Reston, VA, USA, 1987.

81. Potter, L.S. Petrology and Petrogenesis of Tertiary Igneous Rocks, Chico Hills, New Mexico. Master's Thesis, Iowa State University, Ames, IA, USA, 1988.

82. Schreiner, R.A. Preliminary Investigations of Rare-Earth-Element-Bearing Veins, Breccias, and Carbonatites in the Laughlin Peak Area, Colfax County, New Mexico; U.S. Bureau of Mines: Washington, DC, USA, 1991; pp. 93-99.

83. Stroud, J.R. The Geochronology of the Raton-Clayton Volcanic Field, with Implications for Volcanic History and Landscape Evolution. Master's Thesis, New Mexico Institute of Mining and Technology, Socorro, NM, USA, 1997; pp. 1-70.

84. Wargo, J.G. Geology of a disseminated copper deposit near Cerrillos, New Mexico. Econ. Geol. 1964, 59, 1525-1538. [CrossRef]

85. Giles, D.L. Gold mineralization in the Cerrillos district, New Mexico (abstr.). Geol. Soc. Am. Abstr. Programs 1991, 23, 24.

86. Sauer, R.R. Petrochemistry and Geochronology of Plutons Relative to Tectonics in the San Pedro-Ortiz Porphyry Belt, New Mexico. Master's Thesis, University Colorado, Boulder, CO, USA, 1994.

87. Maynard, S.R. Geology and Mineral Resources of the Ortiz Mine Grant, Santa Fe County, New Mexico; Open-File Report 560; New Mexico Bureau of Geology and Mineral Resources: Socorro, NM, USA, 2014; 178p.

88. Kay, B.D. Vein and Breccia Gold Mineralization and Associated Igneous Rocks at the Ortiz Mine, New Mexic, USA. Master's Thesis, Colorado School of Mines, Golden, CO, USA, 1986.

89. Maynard, S.R.; Martin, K.W.; Nelson, C.J.; Schutz, J.L. Geology and Gold Mineralization of the Ortiz Mountains, Santa Fe County, New Mexico; Preprint No. 89-43; Society of Mining, Metallurgy and Exploration: Littleton, CO, USA, 1989; 9p.

90. Maynard, S.R.; Nelson, C.J.; Martin, K.W.; Schutz, J.L. Geology and gold mineralization of the Ortiz Mountains, Santa Fe County, New Mexico. Miner. Eng. 1990, 42, 1007-1011.

91. Schutz, J.L. Gold Mineralization Associated with Alkaline Intrusives at the Carache Canyon Breccia Pipe Prospect, Ortiz Mountains, New Mexico; Guidebook 46; New Mexico Geological Society: Socorro, NM, USA, 1995; pp. 167-173.

92. Kelley, V.C. Geology and Economics of New Mexico Iron Ore Deposits; University of New Mexico, Publications in Geology: Albuquerque, NM, USA, 1949; 246p.

93. McLemore, V.T. Preliminary Report on the Geology and Mineral-Resource Potential of Torrance County, New Mexico; OF-192; New Mexico Bureau of Mines and Mineral Resources: Socorro, NM, USA, 1984; 211p.

94. Griswold, G.B. Mineral Deposits of Lincoln County, New Mexico; Bulletin 67; New Mexico Bureau of Mines and Mineral Resources: Socorro, NM, USA, 1959; pp. 1-117.

95. Glass, J.J.; Smalley, R.G. Bastnaesite (Gallinas Mountains, New Mexico). Am. Miner. 1945, 30, $601-615$. 
96. Kelley, V.C.; Rothrock, H.E.; Smalley, R.G. Geology and Mineral Deposits of the Gallinas District, Lincoln County, New Mexico; Strategic Minerals Investigation Preliminary Map 3-211; Scale 1:62,500; U.S. Geological Survey: Reston, VA, USA, 1946.

97. Soulé, J.H. Exploration of Gallinas Fluorspar Deposits, Lincoln County, New Mexico; Report of Investigations 3854; U.S. Bureau of Mines: Washington, DC, USA, 1946; 25p.

98. Perhac, R.M. Geology and Mineral Deposits of the Gallinas Mountains, New Mexico. Ph.D. Thesis, University of Michigan, Ann Arbor, Michigan, 1961.

99. Perhac, R.M. Geology and Mineral Deposits of the Gallinas Mountains, Lincoln and Torrance Counties, New Mexico; Bulletin 95; New Mexico Bureau of Mines and Mineral Resources: Socorro, NM, USA, 1970; 51p.

100. Perhac, R.M.; Heinrich, E.W. Fluorite-bastnaesite deposits of the Gallinas Mountains, New Mexico and bastnaesite paragenesis. Econ. Geol. 1964, 59, 226-239. [CrossRef]

101. DeMark, R.S. The Red Cloud mines, Gallinas Mountains, New Mexico. Miner. Rec. 1980, 11, 69-72.

102. Korzeb, S.L.; Kness, R.F. Mineral Resource Investigation of the Roswell Resource Area, Chavez, Curry, DeBaca, Guadalupe, Lincoln, Quay and Roosevelt Counties, New Mexico; Open-file Report MLA 12-92; U.S. Bureau of Mines: Washington, DC, USA, 1992; 220p.

103. Woodward, L.A.; Fulp, M.S. Gold Mineralization Associated with Alkali Trachyte Breccias in the Gallinas Mining District, Lincoln County, New Mexico; Guidebook 42; New Mexico Geological Society: Socorro, NM, USA, 1991; pp. 323-325.

104. Schreiner, R.A. Mineral Investigation of the Rare-Earth-Element-Bearing Deposits, Red Cloud Mining District, Gallinas Mountains, Lincoln County, New Mexico; Open-file Report 2-91; U.S. Bureau of Mines: Washington, DC, USA, 1993; 62p.

105. Jackson, W.D.; Christiansen, G. International Strategic Minerals Inventory Summary Report_Rare-Earth Oxides; Circular 930-N; U.S. Geological Survey: Reston, VA, USA, 1993; 76p.

106. Williams-Jones, A.E.; Samson, I.M.; Olivo, G.R. The genesis of hydrothermal fluorite-REE deposits in the Gallinas Mountains, New Mexico. Econ. Geol. 2000, 95, 327-341. [CrossRef]

107. Gagnon, J.E.; Samson, I.M.; Fryer, B.J.; Williams-Jones, A.E. Compositional heterogeneity in fluorite and the genesis of fluorite deposits: Insights from LA-ICP-Ms analysis. Can. Miner. 2003, 41, 365-382. [CrossRef]

108. McLemore, V.T. Geology and Mineral Deposits of the Gallinas Mountains, Lincoln and Torrance Counties, New Mexico; Preliminary Report; Open-File Report OF-532; New Mexico Bureau of Geology and Mineral Resources: Socorro, NM, USA, 2010; 92p.

109. Vance, Z. Mineralogy, Geochemistry and Genesis of the Hydrothermal REE-Fluorite-Ag-Pb-Cu Ore Deposits of the Gallinas Mountains, New Mexico. Master's Thesis, New Mexico Institute of Mining and Technology, Socorro, NM, USA, 2013.

110. Robison, A. ${ }^{40} \mathrm{Ar} /{ }^{39} \mathrm{Ar}$ Geochronology of Magmatism and Alteration in the Gallinas Mountains with Implications for Rare Earth Mineralization. Master's Thesis, New Mexico Institute of Mining and Technology, Socorro, NM, USA, 2017.

111. Robison, A.; McIntosh, W.; Lueth, V.W. ${ }^{40} \mathrm{Ar} /{ }^{39} \mathrm{Ar}$ geochronology of magmatism and alteration in the Gallinas Mountains with implications for rare earth mineralization. In New Mexico Geological Society, Annual Spring Meeting, 7 April 2017; Macey Center, New Mexico Institute Mining Technology: Socorro, NM, USA, 2017; p. 61. Available online: http://nmgs.nmt.edu/meeting/abstracts/view.cfm?aid=540 (accessed on 20 January 2018).

112. Rawson, D.E. Geology of the Tecolote Hills Area, Lincoln County, New Mexico. Master's Thesis, University New Mexico, Albuquerque, NM, USA, 1957.

113. Segerstrom, K.; Ryberg, G.C. Geology and Placer-Gold Deposits of the Jicarilla Mountains, Lincoln County, New Mexico; Bulletin 1308; U.S. Geological Survey: Reston, VA, USA, 1974; 25p.

114. McLemore, V.T.; Ouimette, M.; Eveleth, R.W. Preliminary Observations on the Mining History, Geology and Mineralization of the Jicarilla Mining District, Lincoln County, New Mexico; Guidebook 42; New Mexico Geological Society: Socorro, NM, USA, 1991; pp. 311-316.

115. Grainger, J.R. Geology of the White Oaks Mining District, Lincoln County, New Mexico. Master's Thesis, University New Mexico, Albuquerque, NM, USA, 1974.

116. Ronkos, C.J. Geology, alteration, and gold mineralization in the White Oaks mining district, Lincoln County, New Mexico (abstr.). Geol. Soc. Am. Abstr. Programs 1991, 23, 88. 
117. Koning, D.J.; Kempter, K. Preliminary Geologic Map of the Carrizozo East 7.5-Minute Quadrangle, Lincoln County, New Mexico; Open-File Geologic Map 216; Scale 1:24,000; New Mexico Bureau of Geology and Mineral Resources: Socorro, NM, USA, 2010.

118. Rawling, G.; Koning, D. Geologic Map of the White Oaks South Quadrangle, Lincoln County, New Mexico; Open-File Geologic Map, OF-GM 216; Scale 1:24,000; New Mexico Bureau of Geology and Mineral Resources: Socorro, NM, USA, 2011.

119. Tuftin, S.E. Mineral Investigation of the Capitan Mountains Wilderness Area, Lincoln County, New Mexico; Open-File Report; MLA-20-84; U.S. Bureau Mines: Washington, DC, USA, 1984; 24p.

120. Willis, M.; Campbell, A.; Phillips, R. High salinity fluids associated with allanite mineralization, Capitan Mountains, New Mexico. Geol. Soc. Am. Abstr. Programs 1989, 21, A287.

121. Phillips, R.S. Geochemistry of Hydrothermal Th-U-REE Quartz/Fluorite Veins from the Capitan Pluton. Master's Thesis, New Mexico Institute of Mining and Technology, Socorro, NM, USA, 1990.

122. Phillips, R.S.; Campbell, A.R.; McLemore, V.T. Th-U-REE Quartz-Fluorite Veins, Capitan Pluton, New Mexico: Evidence for a Magmatic-Hydrothermal Origin; Guidebook 42; New Mexico Geological Society: Socorro, NM, USA, 1991; pp. 129-136.

123. Banks, D.A.; Yardley, B.W.D.; Campbell, A.R.; Jarvis, K.E. REE composition of an aqueous magmatic fluid: A fluid inclusion study from the Capitan pluton, New Mexico, USA. Chem. Geol. 1994, 113, 259-272. [CrossRef]

124. Allen, M.S.; McLemore, V.T. The Geology and Petrogenesis of the Capitan Pluton, New Mexico. In Geology of the Sierra Blanca, Sacramento, and Capitan Ranges, New Mexico: New Mexico Geological Society, 42nd Annual Field Conference, Guidebook; Barker, J.M., Kues, B.S., Austin, G.S., Lucas, S.G., Eds.; New Mexico Geological Society: Socorro, NM, USA, 1991; pp. 115-127.

125. Allen, M.S.; Foord, E.E. Geological, geochemical and isotopic characteristics of the Lincoln County porphyry belt, New Mexico: Implications for regional tectonics and mineral deposits. In Geology of the Sierra Blanca, Sacramento, and Capitan Ranges, New Mexico: New Mexico Geological Society, 42nd Annual Field Conference, Guidebook; Barker, J.M., Kues, B.S., Austin, G.S., Lucas, S.G., Eds.; New Mexico Geological Society: Socorro, NM, USA, 1991; pp. 97-113.

126. Campbell, A.R.; Banks, D.A.; Phillips, R.S.; Yardley, B.W.D. Geochemistry of the Th-U-REE mineralizing fluid, Capitan Mountains, New Mexico, USA. Econ. Geol. 1995, 90, 1273-1289. [CrossRef]

127. Ratajeski, K.; Campbell, A.R. Distribution of fluid inclusions in igneous quartz of the Capitan Pluton, New Mexico, USA. Geochim. Cosmochim. Acta. 1994, 58, 1161-1174. [CrossRef]

128. Dunbar, N.W.; Campbell, A.R.; Candela, P.A. Physical, chemical, and mineralogical evidence for magmatic fluid migration within the Capitan pluton, southeastern New Mexico. Geol. Soc. Am. Bull. 1996, 108, 318-333. [CrossRef]

129. Rawling, G.C. Geology of the Capitan and Nogal Quadrangles, Lincoln County, New Mexico; Open-File Report 538; Scale 1:24,000; New Mexico Bureau of Geology and Mineral Resources: Socorro, NM, USA, 2011.

130. Griswold, G.B.; Missaghi, F. Geology and Geochemical Survey of a Molybdenum Deposit near Nogal Peak, Lincoln County, New Mexico; New Mexico Bureau of Mines and Mineral Resources Campus Station: Socorro, NM, USA, 1964; Volume 67, p. 29.

131. Giles, D.L.; Thompson, T.B. Petrology and mineralization of a molybdenum-bearing alkalic stock, Sierra Blanca, New Mexico. Geol. Soc. Am. Bull. 1972, 83, 2129-2148. [CrossRef]

132. Gander, M.J. The Geology of the Northern Part of the Rialto Stock, Sierra Blanca Igneous Complex, New Mexico. Master's Thesis, Colorado State University, Fort Collins, CO, USA, 1982.

133. Briggs, J.P. Mineral Investigation of an Addition to the White Mountain Wilderness, Lincoln County, New Mexico; MLA-33-83; U.S. Bureau of Mines: Washington, DC, USA, 1983; 11p.

134. Ryberg, G.E. Geology of the Vera Cruz Mine and Breccia Pipe, Lincoln County, New Mexico; Guidebook 42; New Mexico Geological Society: Socorro, NM, USA, 1991; pp. 329-332.

135. Douglass, S.E. Characterization of Alkaline Rock-Hosted Precious and Base Metal Mineralization in the Nogal Mining District, Lincoln County, New Mexico. Master's Thesis, New Mexico Institute of Mining and Technology, Socorro, NM, USA, 1992.

136. Douglass, S.E.; Campbell, A.R. Characterization of alkaline rock-related mineralization in the Nogal mining district, Lincoln County, New Mexico. Econ. Geol. 1994, 89, 1306-1321. [CrossRef] 
137. Douglass, S.E.; Campbell, A.R. Characterization of alkaline rock-related mineralization in the Nogal mining district, Lincoln County, New Mexico, Reply. Econ. Geol. 1995, 90, 985-987. [CrossRef]

138. Campbell, A.R.; Porter, J.A.; Scott, E.; Douglass, S.E. Fluid Inclusion Investigation of the Mid-Tertiary Helen Rae Gold Mine, Nogal District, New Mexico; Guidebook 42; New Mexico Geological Society: Socorro, NM, USA, 1991; pp. 317-321.

139. Constantopoulos, J. Geochemistry of the Bonito Lake stock, Lincoln County, New Mexico: Petrogenesis and hydrothermal alteration. Rocky Mt. Geol. 2007, 42, 137-155. [CrossRef]

140. McLemore, V.T.; Goff, F.; McIntosh, W. Geology and Mineral Resources of the Nogal-Bonito Mining District, Lincoln County, New Mexico; Guidebook 65; New Mexico Geological Society: Socorro, NM, USA, 2014; pp. 235-246.

141. Goff, F.; Kelley, S.A.; Lawrence, J.R.; Cikiski, C.; Krier, D.J.; Goff, C.J.; McLemore, V.T. Preliminary Geologic Map of the Nogal Peak Quadrangle, Lincoln and Otero Counties, New Mexico; Open-File Geologic Map OF-GM-134; New Mexico Bureau of Geology and Mineral Resources: Socorro, NM, USA, 2011; 81p.

142. Goff, F.; Roback, R.C.; McIntosh, W.I.; Goff, C.J.; Kluk, E.C. Geochemistry and Geochronology of Intrusive and Volcanic Rocks of the Three Rivers Stock, Sierra Blanca, New Mexico; Guidebook 65; New Mexico Geological Society: Socorro, NM, USA, 2014; pp. 183-196.

143. Kelley, S.; Koning, D.J.; Goff, F.; Cikoski, C.; Peters, L.; McIntosh, W. Stratigraphy of the Northwestern Sierra Blanca Volcanic Field; Guidebook 65; New Mexico Geological Society: Socorro, NM, USA, 2014; pp. 197-208.

144. Cikoski, C.T.; Koning, D.J.; Kelley, S.A.; Zeigler, K.E. Preliminary Geologic Map of the Church Mountain Quadrangle, Lincoln County, New Mexico; Open-File Geologic Map OF-GM-215; Scale 1:24,000; New Mexico Bureau of Geology and Mineral Resources: Socorro, NM, USA, 2011.

145. McLemore, V.T. Geology of the Three Rivers Mining District; Guidebook 65; New Mexico Geological Society: Socorro, NM, USA, 2014; pp. 45-47.

146. Chamberlin, R.M.; McIntosh, W.C.; Peters, L. ${ }^{40} A r /{ }^{39}$ Ar Geochronology of the Jones Camp Dike, Central New Mexico: An Eastward Projection of the Magdalena Radial Dike Swarm from under the Oligocene Socorro-Magdalena Caldera Cluster; Guidebook 60; New Mexico Geological Society: Socorro, NM, USA, 2009; pp. 337-346.

147. Aldrich, M.J., Jr.; Chapin, C.E.; Laughlin, A.W. Stress history and tectonic development of the Rio Grande Rift, New Mexico. J. Geophys. Res. 1986, 91, 6199-9211. [CrossRef]

148. North, R.M. Geology and Ore Deposits of the Orogrande Mining District, Otero County, New Mexico; OF-370; New Mexico Bureau of Mines and Mineral Resources: Socorro, NM, USA, 1982; 23p.

149. Seager, W.R. Geology of the Organ Mountains and Southern San Andres Mountains, New Mexico; Memoir 36; New Mexico Bureau of Mines and Mineral Resources: Socorro, NM, USA, 1981; 97p.

150. Seager, W.R.; McCurry, M. The cogenetic Organ cauldron and batholith, south-central New Mexico: Evolution of a large-volume ash-flow cauldron and its source magma chamber. J. Geophys. Res. 1988, 93, 4421-4433. [CrossRef]

151. Newcomer, R.W., Jr.; Giordano, T.H. Porphyry-type mineralization and alteration in the Organ mining district, south-central New Mexico. N. M. Geol. 1986, 8, 83-86.

152. McLemore, V.T.; Sutphin, D.M.; Hack, D.R.; Pease, T.C. Mining History and Mineral Resources of the Mimbres Resource Area, Doña Ana, Luna, Hidalgo, and Grant Counties, New Mexico; Open-File Report 424; New Mexico Bureau of Mines and Mineral Resources: Socorro, NM, USA, 1996; 251p.

153. Lueth, V.W. Tellurium Mineralization in the Northern Organ District, Dona Ana County, New Mexico; Guidebook 49; New Mexico Geological Society: Socorro, NM, USA, 1998; pp. 265-269.

154. Lueth, V.W.; McLemore, V.T. A Reinterpretation of Ore Zoning in the Organ District, Doña Ana County, New Mexico; Guidebook 49; New Mexico Geological Society: Socorro, NM, USA, 1998; pp. 279-285.

155. Verplanck, P.L.; Farmer, G.L.; McCurry, M.; Mertzman, S.; Snee, L.W. Isotopic evidence on the origin of compositional layering in an epizonal magma body. Earth Planet. Sci. Lett. 1995, 136, 31-41. [CrossRef]

156. Verplanck, P.L.; Farmwe, G.L.; McCurry, M.; Mertzman, S.A. The chemical and isotopic differentiation of an epizonal magma body: Organ Needle pluton, New Mexico. J. Petrol. 1999, 40, 653-678. [CrossRef]

157. Zimmerer, M.J.; McIntosh, W.C. Geochronologic evidence of upper-crustal in situ differentiation: Silicic magmatism at the Organ caldera complex, New Mexico. Geosphere 2013, 9, 155-169. [CrossRef]

158. Zapp, A.D. Geology of the Northeastern Cornudas Mountains, New Mexico. Master's Thesis, University of Texas at Austin, Austin, TX, USA, 1941. 
159. Clabaugh, S.E. Geology of the Northwestern Portion of the Cornudas Mountains, New Mexico. Master's Thesis, University of Texas at Austin, Austin, TX, USA, 1941.

160. Timm, B.C. The Geology of the Southern Cornudas Mountains, Texas and New Mexico, Master's Thesis, University of Texas at Austin, Austin, TX, USA, 1941.

161. Clabaugh, S.E. Eudialyte and eucolite from southern New Mexico (abstr.). Am. Miner. 1950, 35, $279-280$.

162. Collins, G.E. Preliminary Reconnaissance for Uranium in the Cornudas Mountains, Otero County, New Mexico and Hudspeth County, Texas; Report DBO-4-TM-5; U.S. Atomic Energy Commission: Washington, DC, USA, 1958; 16p.

163. Warner, L.A.; Holser, W.T.; Wilmarth, V.R.; Cameron, E.N. Occurrence of Nonpegmatite Beryllium in the United States; Professional Paper; U.S. Geological Survey: Reston, VA, USA, 1959; Volume 318, 198p.

164. Barker, D.S.; Hodges, F.N. Mineralogy of intrusions in the Diablo Plateau, northern Trans-Pecos magmatic province, Texas and New Mexico. Geol. Soc. Am. Bull. 1977, 88, 1428-1436. [CrossRef]

165. Barker, D.S.; Long, L.E.; Hoops, C.K.; Hodges, F.N. Petrology and Rb-Sr isotope geochemistry of intrusions in the Diablo Plateau, northern Trans-Pecos magmatic province, Texas and New Mexico. Geol. Soc. Am. Bull. 1977, 88, 1437-1446. [CrossRef]

166. Henry, C.D.; McDowell, F.W.; Price, J.G.; Smyth, R.C. Compilation of Potassium-Argon Ages of Tertiary Igneous Rocks, Trans Pecos Texas; Geologic Circular 86-2; University of Texas at Austin, Bureau of Economic Geology: Austin, TX, USA, 1986; 34p.

167. McLemore, V.T.; Guilinger, J.R. Geology and Mineral Resources of the Cornudas Mountains, Otero County, New Mexico and Hudspeth County, Texas; Guidebook 44; New Mexico Geological Society: Socorro, NM, USA, 1993; pp. 145-154.

168. Schreiner, R.A. Mineral Investigation of Wind Mountain and the Chess Draw Area, Cornudas Mountains, Otero County, New Mexico; MLA 26-94; U.S. Bureau of Mines: Washington, DC, USA, 1994; 51p.

169. McLemore, V.T.; Lueth, V.W.; Pease, T.C.; Guilinger, J.R. Petrology and mineral resources of the Wind Mountain laccolith, Cornudas Mountains, New Mexico and Texas. Can. Miner. 1996, 34, 335-347.

170. Nutt, C.J.; O’Neille, J.M.; Kleinkopf, M.D.; Klein, D.P.; Miller, W.R.; Rodriquez, B.D.; McLemore, V.T. Geology and Mineral Resources of the Cornudas Mountains, New Mexico; Open File Report OF97-282; U.S. Geological Survey: Reston, VA, USA, 1997; 46p.

171. New Mexico Bureau of Mines and Mineral Resources; New Mexico State University Southwest Technology Institute; TRC Mariah Associates, Inc. Mineral and Energy Resource Assessment of the McGregor Range (Fort Bliss), Otero County, New Mexico; OF-458; New Mexico Bureau of Mines and Mineral Resources: Socorro, NM, USA, 1998; 543p.

172. McLemore, V.T. Geology and Geochemistry of the Mid-Tertiary Alkaline to Calc-Alkaline Intrusions in the Northern Hueco Mountains and Adjacent Areas, McGregor Range, Southern Otero County, New Mexico; Guidebook 52; New Mexico Geological Society: Socorro, NM, USA, 2002; pp. 129-137.

173. Shannon, W.M. Lithogeochemical Characterization of Intrusive Rocks Comprising the Quitman-Sierra Blanca Igneous Complex, Hudspeth County, Texas. Master's Thesis, University of Texas at El Paso, El Paso, TX, USA, 1986.

174. Shannon, W.M.; Goodell, P.C. Lithogeochemistry of Intrusive Rocks of the Quitman-Sierra Blanca Igneous Complex, Hudspeth County, Texas; Price, J.G., Henry, C.D., Parker, D.F., Barker, D.S., Eds.; In Igneous Geology of Trans-Pecos Texas; Guidebook 23; Texas Bureau of Economic Geology; University of Texas at Austin: Austin, TX, USA, 1986; pp. 225-226.

175. Rubin, J.N.; Price, J.G.; Henry, C.D.; Koppenaal, D.W. Cryolite-bearing and rare metal-enriched rhyolite, Sierra Blanca Peaks, Hudspeth County, Texas. Am. Miner. 1987, 72, 1122-1130.

176. Rubin, J.N.; Price, J.G.; Henry, C.D.; Pinkston, T.L.; Tweedy, S.W.; Koppenaal, D.W.; Peterson, S.B.; Harlan, H.M.; Miller, W.T.; Thompson, R.J.; et al. Mineralogy of Beryllium Deposits Near Sierra Blanca, Texas; InPrecious and Rare Metals Technologies; Torma, A.E., Gundiler, I.H., Eds.; Elsevier: Amsterdam, The Netherlands, 1988; pp. 601-614.

177. Rubin, J.N.; Henry, C.D.; Price, J.G. Hydrothermal zircons and zircon overgrowths, Sierra Blanca Peaks, Texas. Am. Miner. 1989, 74, 865-869.

178. Rubin, J.N.; Price, J.G.; Henry, C.D.; Kyle, J.R. Industrial minerals of the Delaware Basin, Texas and New Mexico. In Geology of the Beryllium-Rare Earth Element Deposits at Sierra Blanca, West Texas; Guidebook 8; Kyle, J.R., Ed.; Society of Economic Geologists: Littleton, CO, USA, 1990; pp. 191-203. 
179. Price, J.G.; Rubin, J.N.; Henry, C.D.; Pinkston, T.L.; Tweedy, S.W.; Koppenaal, D.W. Rare-Metal Enriched Peraluminous Rhyolites in a Continental Arc, Sierra Blanca Area, Trans-Pecos Texas; Chemical Modification by Vapor-Phase Crystallization. In Ore-Bearing Granite Systems; Petrogenesis and Mineralizing Processes; Special Paper 246; Stein, H.J., Hannah, J.L., Eds.; Geological Society of America: Littleton, CO, USA, 1990; pp. 103-120.

180. Standard Silver Corporation, Round Top Beryllium, Uranium, Rare Earth Project: Unpublished Company Report. 2008. Available online: http:/ / www.standardsilvercorp.com/main-sect/uploads/08/round_top_ presentation.pdf (accessed on 3 February 2010).

181. Henry, C.D.; McIntosh, W.; McDowell, F.W.; Lipman, P.W.; Chapin, C.E.; Richardson, M.T. Distribution, timing, and controls of the Mid-Cenozoic ignimbrite flare-up in western North America (abstr.). Geol. Soc. Am. Abstr. Programs 2010, 42, 144.

182. Quintana, A.G. Rare Earth Element Geochemistry of the Sierra Blanca laccoliths, Texas. Master's Thesis, University of Texas at El Paso, El Paso, TX, USA, 2013.

183. Kyger, N. Geology and Geochemistry of the Sierra Blanca Rare Earth Complex, Sierra Blanca, Texas. Master's Thesis, University of Texas at El Paso, El Paso, TX, USA, 2013.

184. Pingitore, N.; Clague, J.; Gorski, D. Round Top Mountain rhyolite (Texas, USA), a massive Y-bearing-fluoritehosted heavy rare earth element (HRRE) deposit. J. Rare Earth. 2014, 32, 90-96. [CrossRef]

185. Hulse, D.E.; Newton, M.C., III. Malhotra, Deepak, Amended NI 43-101 Preliminary Economic Assessment, Round Top Project, Sierra Blanca, Texas, Prepared for Texas Rare Earth Resources: Lakewood, Colo., Gustavson Associates LLC, 28 April 2014. 206p. Available online: http://trer.com/_resources/reports/ Amended_TRER_NI43-101_PEA_FINAL_28April2014.pdf (accessed on 21 January 2018).

186. Elliott, B.A.; O’Neill, L.C.; Kyle, J.R. Mineralogy and crystallization history of a highly differentiated REE-enriched hypabyssal rhyolite: Round Top laccolith, Trans-Pecos, Texas. Miner. Petrol. 2017, 111, 569-592.

187. Levinson, A.A. Beryllium-fluorine mineralization at Aguachile Mountains, Coahuila, Mexico. Am. Miner. 1962, 47, 67-74.

188. McAnulty, W.N.; Sewell, C.R.; Atkinson, D.R.; Raspberry, J.M. Aguachile beryllium-bearing fluorspar district, Coahuila, Mexico. Geol. Soc. Am. Bull. 1963, 74, 735-743. [CrossRef]

189. Simkins, T.H. Geology and Geochemistry of the Aguachile Mountain Fluorspar-Beryllium Mining District, Northern Coahuila, Mexico. Master's Thesis, Sul Ross State University, Alpine, TX, USA, 1983.

190. LeMaitre, R.W. (Ed.) A Classification of Igneous Rocks and Glossary of Terms; Blackwell Scientific Publications: Oxford, UK, 1989; 193p.

191. De la Roche, H.; Leterrier, J.; Grandclaude, P.; Marchal, M. A classification of volcanic and plutonic rocks using R1, R2-diagrams and major element analysis-Its relationships with current nomenclature. Chem. Geol. 1980, 29, 183-210. [CrossRef]

192. Nakamura, N. Determination of REE, Ba, Fe, Mg, $\mathrm{Na}$, and $\mathrm{K}$ in carbonaceous and ordinary chondrites. Geochim. Cosmochim. Acta 1974, 38, 757-775. [CrossRef]

193. Woolley, A.R.; Kempe, D.R.C. Carbonatites: Nomenclature, average chemical compositions and element distribution. In Carbonatites: Genesis and Evolution; Bell, K., Ed.; Unwin Hyman: London, UK, 1989; pp. 1-14.

194. Gittins, J.; Harmer, R.E. What is a Ferrocarbonatite? A Revised Classification. J. Afr. Earth Sci. 1997, 25, 159-168. [CrossRef]

195. McAnulty, W.N. Fluorspar in New Mexico; Memoir 34; New Mexico Bureau of Mines and Mineral Resources: Socorro, NM, USA, 1978; 64p.

196. Staatz, M.H. Thorium Resources, 1974; Open-File Report 76-690; U.S. Geological Survey: Reston, VA, USA, 1974; 4p.

197. King, W.E.; Harder, V.M. Oil and Gas Potential of the Tularosa Basin-Otero Platform-Salt Basin Graben Area, New Mexico and Texas; Circular 198; New Mexico Bureau of Mines and Mineral Resources: Socorro, NM, USA, 1985; 36p.

198. Jowitt, S.M.; Medlin, C.C.; Cas, R.A.F. The rare earth element (REE) mineralisation potential of highly fractionated rhyolites: A potential low-grade, bulk tonnage source of critical metals. Ore Geol. Rev. 2017, 86, 548-562. [CrossRef]

199. McMillan, N.J.; Dickin, A.P.; Haag, D. Evolution of magma source regions in the Rio Grande rift, southern New Mexico. Geol. Soc. Am. 2000, 112, 1582-1593. [CrossRef] 
200. Anthony, E.Y. Source regions of granites and their links to tectonic environment: Examples from the western United States. Lithos 2005, 80, 61-74. [CrossRef]

201. Stein, H.J.; Crock, J.C. Late Cretaceous-Tertiary magmatism in the Colorado mineral belt; rare earth element and samarium-neodymium isotopic studies, in the nature and origin of Cordilleran magmatism. Geol. Soc. Am. Mem. 1990, 174, 195-223.

202. Potter, L.S.; Nordlie, B.; Stormer, J.C. Evolution of the Chico Hills alkalic sill complex, northeast New Mexico: Chemical, mineralogical and isotopic evidence (abstr.). Geol. Soc. Am. Abstr. Programs 1991, 23, 57.

203. Bell, K.; Kjarsgaard, B.A.; Simonett, A. Carbonatites-Into the twenty-first century. J. Petrol. 1999, 39, 1839-1845. [CrossRef]

204. Chapin, C.E. Origin of the Colorado mineral belt. Geosphere 2012, 8, 28-43. [CrossRef]

205. Mitchell, R.H. Carbonatites and carbonatites and carbonatites. Can. Miner. 2005, 43, 2049-2068. [CrossRef]

206. Chakhmouradlan, A.R.; Zaltsev, A.N. Rare earth mineralization in igneous rocks: Sources and processes. Elements 2012, 8, 347-353. [CrossRef]

207. Pilet, S.; Baker, M.B.; Stolper, E.M. Metasomatized lithosphere and the origin of alkaline lavas. Science 2008, 320, 916-919. [CrossRef] [PubMed]

208. Weidendorfer, D.; Schmidt, M.W.; Mattsson, H.B. A common origin of carbonatite magmas. Geology 2017, 45, 507-510. [CrossRef]

209. Sillitoe, R.H. Some metallogenic features of gold and copper deposits related to alkaline rocks and consequences for exploration. Miner. Depos. 2002, 37, 4-13. [CrossRef]

(C) 2018 by the author. Licensee MDPI, Basel, Switzerland. This article is an open access article distributed under the terms and conditions of the Creative Commons Attribution (CC BY) license (http://creativecommons.org/licenses/by/4.0/). 